\title{
Water Resources of Parowan Valley, Iron County, Utah
}

Scientific Investigations Report $2017-5033$

U.S. Department of the Interior

U.S. Geological Survey 
Cover photograph: Parowan Valley looking east toward the Red Cliffs.

Photograph by Tom Marston, U.S. Geological Survey, November 2013. 


\section{Water Resources of Parowan Valley, Iron County, Utah}

By Thomas M. Marston

Prepared in cooperation with the Utah Department of Natural Resources

Scientific Investigations Report 2017-5033 


\title{
U.S. Department of the Interior \\ RYAN K. ZINKE, Secretary
}

\section{U.S. Geological Survey William H. Werkheiser, Acting Director}

\author{
U.S. Geological Survey, Reston, Virginia: 2017
}

For more information on the USGS - the Federal source for science about the Earth, its natural and living resources, natural hazards, and the environment-visit http://www.usgs.gov or call 1-888-ASK-USGS.

For an overview of USGS information products, including maps, imagery, and publications, visit http://store.usgs.gov/.

Any use of trade, firm, or product names is for descriptive purposes only and does not imply endorsement by the U.S. Government.

Although this information product, for the most part, is in the public domain, it also may contain copyrighted materials as noted in the text. Permission to reproduce copyrighted items must be secured from the copyright owner.

Suggested citation:

Marston, T.M., 2017, Water resources of Parowan Valley, Iron County, Utah: U.S. Geological Survey Scientific Investigations Report 2017-5033, 45 p., https://doi.org/10.3133/sir20175033.

ISSN 2328-0328 (online) 


\section{Contents}

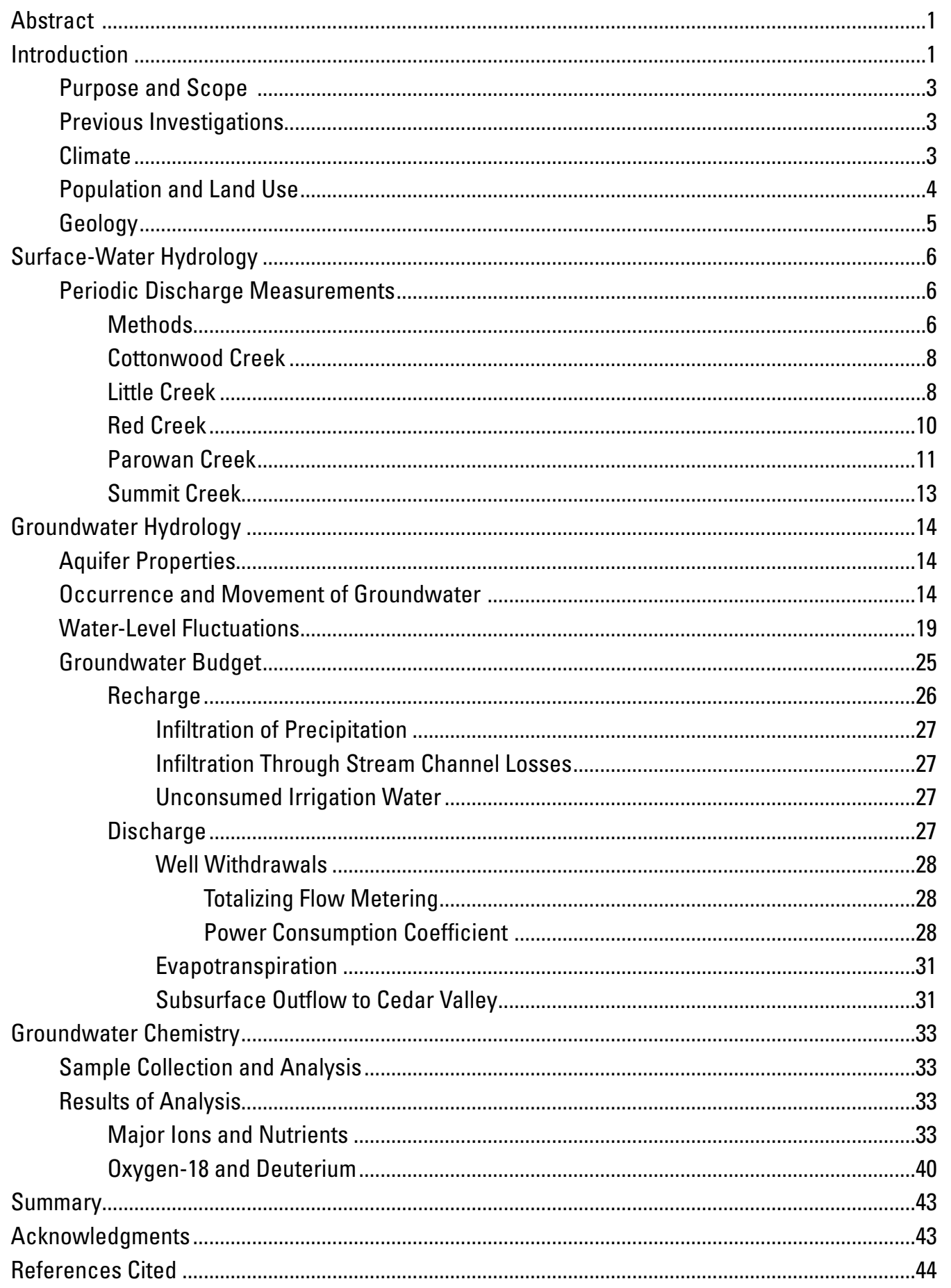




\section{Figures}

1. Map showing location of the Parowan Valley study area, Iron County, Utah . .2

2. Graph showing long-term annual precipitation records at two weather stations in and near the Parowan Valley study area, Iron County, Utah

3. Graph showing annual precipitation record at three SNOTEL stations in and near the Parowan Valley study area, Iron County, Utah

4. Map showing locations of stream measurement sites, springs, and hydroelectric power plants within the Parowan Valley drainage area, Iron County, Utah

5. Graph showing discharge of Little Creek from March 2013 through September 2014, Parowan Valley, Iron County, Utah

6. Graph showing discharge of Red Creek from March 2013 through September 2014, Parowan Valley, Iron County, Utah

7. Graph showing discharge of Parowan Creek from March 2013 through September 2014, Parowan Valley, Iron County, Utah

8. Graph showing discharge of Summit Creek from March 2013 through September 2014, Parowan Valley, Iron County, Utah

9. Map showing regional groundwater-level contour map for the basin-fill aquifer in November 2013, Parowan Valley and northern Cedar Valley, Iron County, Utah

10. Graph showing long-term water-level fluctuations in selected wells in Parowan Valley, Iron County, Utah

11. Map showing water-level change in the basin-fill aquifer from November 2012 to November 2013, Parowan Valley, Iron County, Utah .....

12. Map showing water-level change in the basin-fill aquifer from 1974 to 2013, Parowan Valley, Iron County, Utah

13. Diagram showing conceptualized hydrologic setting and groundwater system in the Parowan Valley study area, Iron County, Utah .

14. Map showing annual groundwater withdrawals in 2013 from wells in Parowan Valley, Iron County, Utah

15. Graph showing comparison of annual groundwater withdrawals calculated by the Totalizing Flow Meter and Power Consumption Coefficient methods for 13 wells in 2013, Parowan Valley, Iron County, Utah

16. Map showing location and classification of evapotranspiration units used to calculate average annual evapotranspiration of groundwater in Parowan Valley, Iron County, Utah

17. Trilinear diagram showing major-ion water quality for selected wells in Parowan Valley, Iron County, Utah

18. Map showing concentration of measured and calculated dissolved solids in water from 73 wells sampled during 2013 in Parowan Valley, Iron County, Utah ..

19. Graph showing relation between dissolved-solids concentration and specific conductance in water from 34 wells sampled during 2013 in Parowan Valley, Iron County, Utah

20. Map showing locations of samples analyzed for stable isotopes in groundwater and surfacewater during 2013 in Parowan Valley and northern Cedar Valley, Iron County, Utah

21. Graph showing relation between delta deuterium $(2 \mathrm{H})$ and delta oxygen-18 for ground and surface-water samples collected in 2013 from Parowan Valley, Iron County, Utah 


\section{Tables}

1. Annual streamflow for five streams that drain the Markagunt Plateau east of Parowan Valley, Iron County, Utah ...

2. Discharge measurements of five streams and tributaries made during 2013-14 that enter Parowan Valley, Iron County, Utah

3. Water levels measured during 2012-14 in wells from Parowan Valley and Cedar Valley, near Enoch, Iron County, Utah .............................................................................16

4. Groundwater budget from 1994 through 2013 for Parowan Valley, Iron County, Utah .........26

5. Evapotranspiration unit rates and areas used to calculate average annual evapotranspiration of groundwater in Parowan Valley, Iron County, Utah

6. Measured field parameters and dissolved concentrations of major ions and nutrients for groundwater sampled during 2013 in Parowan Valley, Iron County, Utah

7. Stable-isotope concentrations in water from groundwater and surface water sampled during 2013 in Parowan Valley and northern Cedar Valley, Iron County, Utah 


\section{Conversion Factors, Datums, and Water-Quality Units}

Inch/Pound to International System of Units

\begin{tabular}{|c|c|c|}
\hline Multiply & By & To obtain \\
\hline \multicolumn{3}{|c|}{ Length } \\
\hline inch (in.) & 2.54 & millimeter (mm) \\
\hline foot $(\mathrm{ft})$ & 0.3048 & meter $(\mathrm{m})$ \\
\hline mile (mi) & 1.609 & kilometer $(\mathrm{km})$ \\
\hline \multicolumn{3}{|c|}{ Area } \\
\hline acre & 4,047 & square meter $\left(\mathrm{m}^{2}\right)$ \\
\hline square mile $\left(\mathrm{m}^{2}\right)$ & 2.59 & square kilometer $\left(\mathrm{km}^{2}\right)$ \\
\hline \multicolumn{3}{|c|}{ Volume } \\
\hline acre-foot (acre-ft) & 1,233 & cubic meter $\left(\mathrm{m}^{3}\right)$ \\
\hline \multicolumn{3}{|c|}{ Flow rate } \\
\hline acre-foot per year (acre-ft/yr) & 1,233 & cubic meter per year $\left(\mathrm{m}^{3} / \mathrm{yr}\right)$ \\
\hline cubic foot per second $(\mathrm{ft} 3 / \mathrm{s})$ & 0.02832 & cubic meter per second $\left(\mathrm{m}^{3 / \mathrm{s}}\right)$ \\
\hline foot per year $(\mathrm{ft} / \mathrm{yr})$ & 0.3048 & meter per year $(\mathrm{m} / \mathrm{yr})$ \\
\hline gallon per minute (gal/min) & 0.06309 & liter per second $(\mathrm{L} / \mathrm{s})$ \\
\hline \multicolumn{3}{|c|}{ Hydraulic conductivity } \\
\hline foot per day (ft/d) & 0.3048 & meter per day $(\mathrm{m} / \mathrm{d})$ \\
\hline square foot per day $\left(\mathrm{ft}^{2} / \mathrm{d}\right)$ & 0.0929 & square meter per day $\left(\mathrm{m}^{2} / \mathrm{d}\right)$ \\
\hline
\end{tabular}

Temperature in degrees Celsius $\left({ }^{\circ} \mathrm{C}\right)$ can be converted to degrees Fahrenheit ( ${ }^{\circ} \mathrm{F}$ ) as follows:

$$
{ }^{\circ} \mathrm{F}=\left(1.8 \times{ }^{\circ} \mathrm{C}\right)+32
$$

Temperature in degrees Fahrenheit $\left({ }^{\circ} \mathrm{F}\right)$ can be converted to degrees Celsius $\left({ }^{\circ} \mathrm{C}\right)$ as follows:

$$
{ }^{\circ} \mathrm{C}=\left({ }^{\circ} \mathrm{F}-32\right) / 1.8
$$

Vertical coordinate information is referenced to the North American Vertical Datum of 1929 (NAVD 29). Horizontal coordinate information is referenced to the North American Datum of 1983 (NAD 83). Altitude, as used in this report, refers to distance above the vertical datum.

Specific conductance is given in microsiemens per centimeter at 25 degrees Celsius $\left(\mu \mathrm{S} / \mathrm{cm}\right.$ at $\left.25^{\circ} \mathrm{C}\right)$. Concentrations of chemical constituents in water are given in either milligrams per liter $(\mathrm{mg} / \mathrm{L})$ or micrograms per liter $(\mu \mathrm{g} / \mathrm{L})$.

Stable-isotope ratios in water are given in units of permil $(\%)$. 


\section{Abbreviations}

$\begin{array}{ll}\text { BCM } & \text { Basin Characterization Model } \\ \text { ET } & \text { evapotranspiration } \\ \text { ET }_{g} & \text { groundwater evapotranspiration } \\ \text { PCC } & \text { power consumption coefficient } \\ \text { TFM } & \text { totalizing flow meter } \\ \text { USGS } & \text { U.S. Geological Survey } \\ \text { WY } & \text { water year }\end{array}$




\section{Wells by the Cadastral System of Land Subdivision}

The well-numbering system used in Utah is based on the Cadastral system of land subdivision. The well-numbering system is familiar to most water users in Utah, and the well number shows the location of the well by quadrant, township, range, section, and position within the section. Well numbers for most of the State are referenced to the Salt Lake Base Line and Meridian. This system is also used for spring numbers.

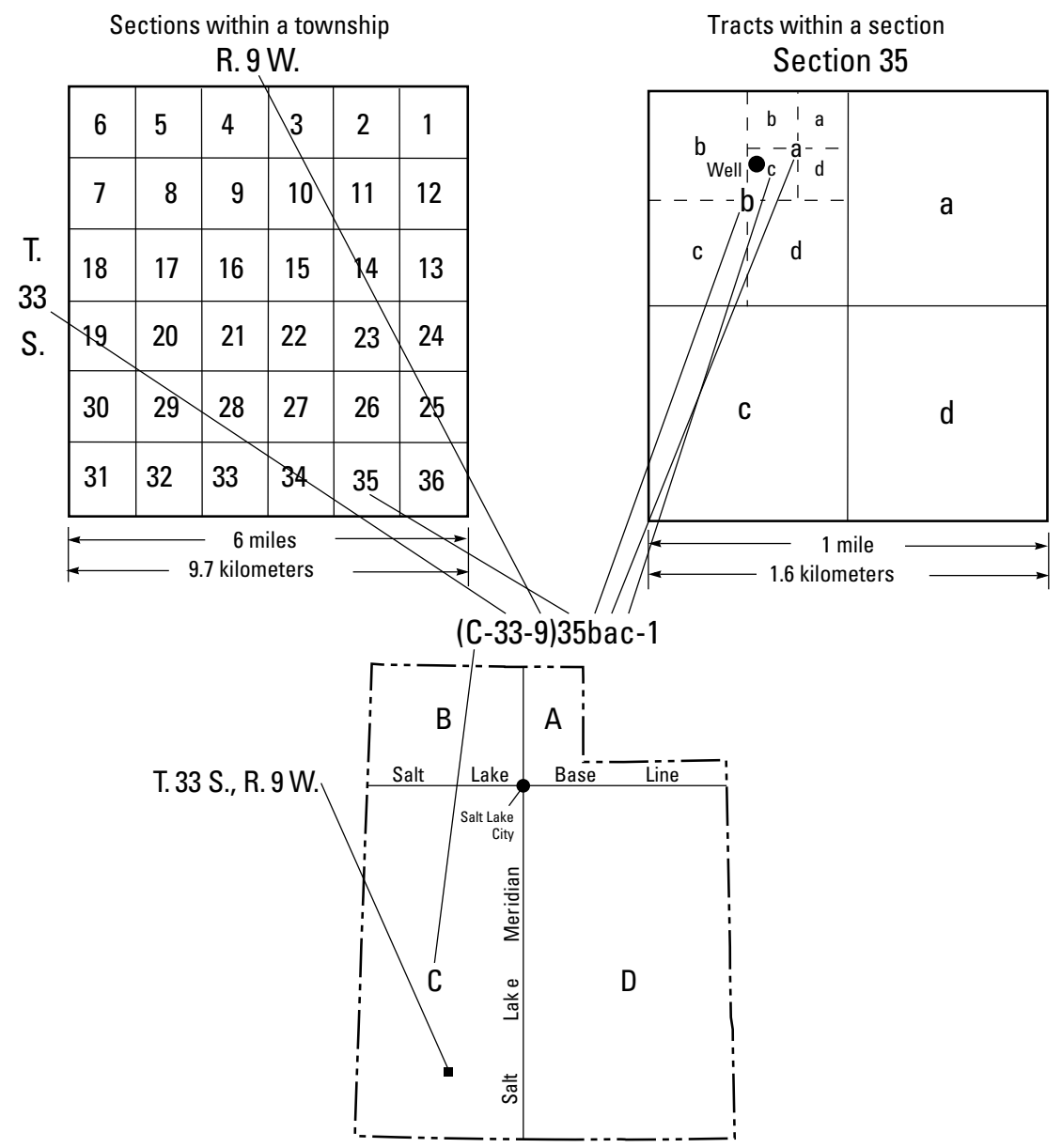

\section{Surface-Water Sites-Downstream Order and Station Number}

Since October 1, 1950, hydrologic-station records in U.S. Geological Survey reports have been listed in order of downstream direction along the mainstem. All stations on a tributary entering upstream from a mainstem station are listed before that station. A station on a tributary entering between two mainstem stations is listed between those stations.

As an added means of identification, each hydrologic station and partial-record station has been assigned a station number. These station numbers are in the same downstream order used in this report. In assigning a station number, no distinction is made between partial-record stations and other stations; therefore, the station number for a partial-record station indicates downstream order position in a list comprising both types of stations. Gaps are consecutive. The complete 8-digit (or 10-digit) number for each station such as 10125600, which appears just to the left of the station name, includes a 2-digit part number "10" plus the 6-digit (or 8-digit) downstream order number "125600." In areas of high station density, an additional two digits may be added to the station identification number to yield a 10-digit number. The stations are numbered in downstream order as described above between stations of consecutive 8-digit numbers. 


\title{
Water Resources of Parowan Valley, Iron County, Utah
}

\author{
By Thomas M. Marston
}

\section{Abstract}

Parowan Valley, in Iron County, Utah, covers about 160 square miles west of the Red Cliffs and includes the towns of Parowan, Paragonah, and Summit. The valley is a structural depression formed by northwest-trending faults and is, essentially, a closed surface-water basin although a small part of the valley at the southwestern end drains into the adjacent Cedar Valley. Groundwater occurs in and has been developed mainly from the unconsolidated basin-fill aquifer. Long-term downward trends in groundwater levels have been documented by the U.S. Geological Survey (USGS) since the mid-1950s. The water resources of Parowan Valley were assessed during 2012 to 2014 with an emphasis on refining the understanding of the groundwater and surface-water systems and updating the groundwater budget.

Surface-water discharge of five perennial mountain streams that enter Parowan Valley was measured from 2013 to 2014. The total annual surface-water discharge of the five streams during 2013 to 2014 was about 18,000 acre-feet (acre-ft) compared to the average annual streamflow of about 22,000 acre-ft from USGS streamgages operated on the three largest of these streams from the 1940s to the 1980s. The largest stream, Parowan Creek, contributes more than 50 percent of the annual surface-water discharge to the valley, with smaller amounts contributed by Red, Summit, Little, and Cottonwood Creeks.

Average annual recharge to the Parowan Valley groundwater system was estimated to be about 25,000 acre-ft from 1994 to 2013. Nearly all recharge occurs as direct infiltration of snowmelt and rainfall on the Markagunt Plateau east of the valley. Smaller amounts of recharge occur as infiltration of streamflow and unconsumed irrigation water near the east side of the valley on alluvial fans associated with mountain streams at the foot of the Red Cliffs. Subsurface flow from the mountain block to the east of the valley is a significant source of groundwater recharge to the basin-fill aquifer. Groundwater flows from the high-altitude recharge areas downward toward the basin-fill aquifer in Parowan Valley. Almost all groundwater discharge occurs as withdrawals from irrigation wells in the valley with a small amount of discharge from phreatophytic evapotranspiration. Subsurface groundwater discharge to Cedar Valley is likely minimal. Withdrawals from wells during 2013 were about 32,000 acre-ft. The estimated withdrawals from wells from 1994 to 2013 have ranged from 22,000 to
39,000 acre-ft per year. Declining water levels are an indication of the estimated average annual decrease in groundwater storage of 15,000 acre-ft from 1994 to 2013.

Groundwater and surface-water samples were collected from 46 sites in Parowan Valley and Cedar Valley near the town of Enoch during June 2013. Groundwater samples from 34 wells were submitted for geochemical analysis. The total dissolved-solids concentration in water from these wells ranged from 142 to 886 milligrams per liter. Results of stable isotope analysis of oxygen and deuterium from groundwater and surface-water samples indicate that most of the groundwater in Parowan Valley and in Cedar Valley near Enoch is similar in isotopic composition to water from mountain streams, which reflects meteoric water recharged in high-altitude areas east of the valley. In addition, results of stable isotope analysis of a subset of samples from wells located near Little Salt Lake may indicate recharge of precipitation that occurred during cooler climatic conditions of the Pleistocene Epoch.

\section{Introduction}

Parowan Valley is a rural valley located in southwestern Utah about 20 miles (mi) northeast of Cedar City (fig. 1). It is a typical Basin and Range valley bounded by mountains with large range-front faults along its margins and characterized by varying thickness of unconsolidated basin-fill deposits within the down-dropped valley basin. Parowan Valley is about $30 \mathrm{mi}$ long and ranges from about 1 to $7 \mathrm{mi}$ wide, covering about 160 square miles $\left(\mathrm{mi}^{2}\right)$. The altitude of Parowan Valley ranges from about 6,200 feet ( $\mathrm{ft}$ ) along the upper portions of the alluvial fans on the east side of the valley to $5,690 \mathrm{ft}$ at Little Salt Lake. Although Parowan Valley is essentially a closed basin with Little Salt Lake functioning as a terminus for most surface water, a small part of the valley (about $12 \mathrm{mi}^{2}$ ) at the southwestern end drains through Winn Gap into Cedar Valley. Surface-water resources make up a significant portion of the water availability in the valley. The five streams that enter the valley on the east side (Summit Creek, Parowan Creek, Red Creek, Little Creek, and Cottonwood Creek) are completely captured during the growing season (April through October). During the winter months, surface water is managed for replenishing soil moisture in agricultural fields and natural streambed recharge. The surface-water resources are generally used for agriculture on the east side of the valley around the 


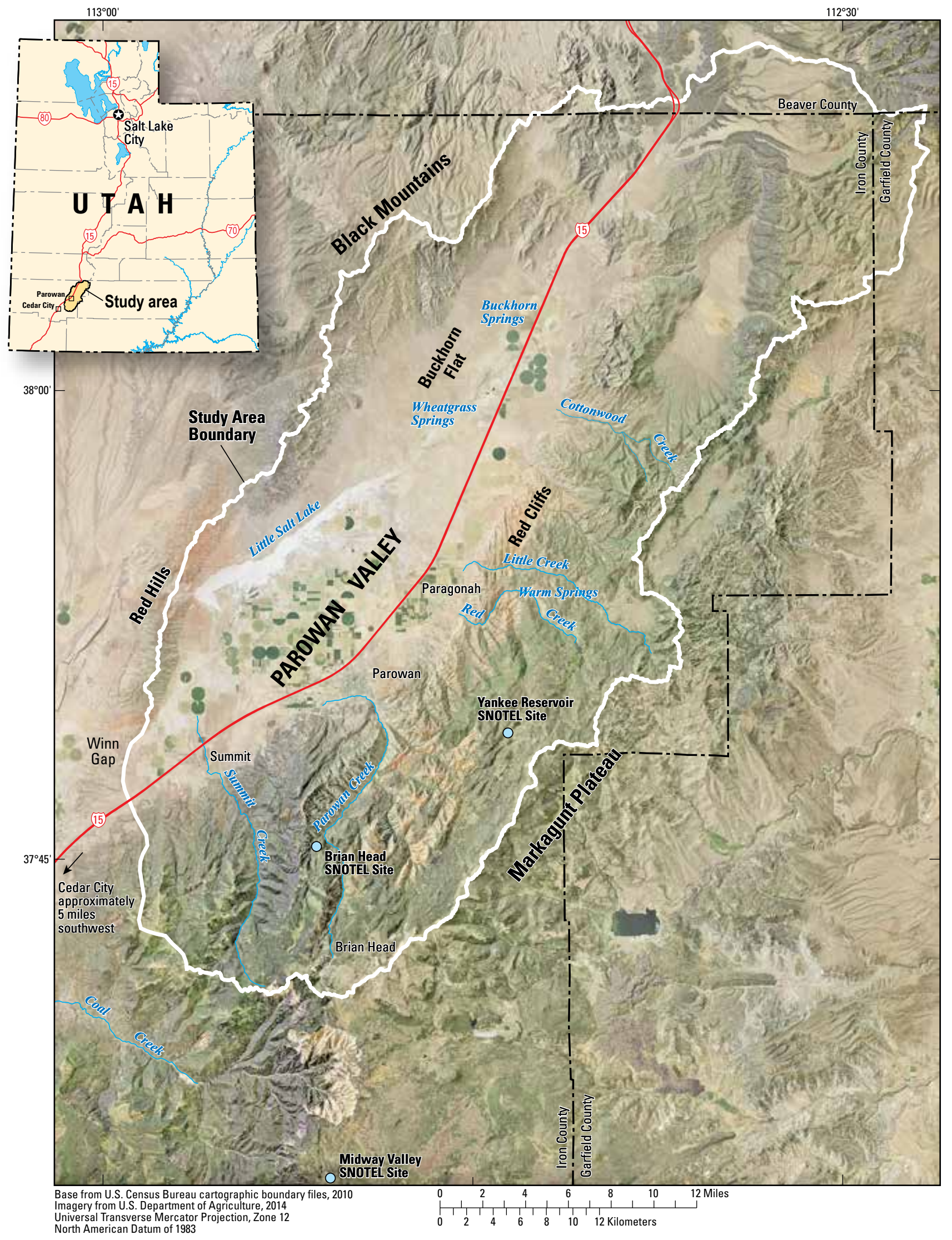

Figure 1. Location of the Parowan Valley study area, Iron County, Utah. 
towns of Summit, Parowan, and Paragonah. Groundwater withdrawals are used primarily for agriculture with a minimal volume being consumed by domestic users mainly outside the towns of Parowan, Paragonah, and Summit. Paragonah and Summit receive their domestic water from nearby springs located in the mountains to the east, whereas the town of Parowan receives domestic water from a well located near the mouth of Parowan Canyon.

Parowan Valley experienced significant growth in agricultural land use during the 1960s and early 1970s. During this period, withdrawals from groundwater increased from about 15,000 acre-feet per year (acre-ft/yr) in 1960 to about 34,000 acre-ft/yr by 1975 (Burden and others, 2015). More recently, suburban expansion in Cedar Valley coupled with similarly timed agricultural land-use development have increased groundwater withdrawals in the region. Water managers are concerned about increasing demands on the local water supplies. Given the proximity of Cedar Valley and Parowan Valley and the similar declines in groundwater levels observed in each valley, new estimates for groundwater budgets are necessary. A study was conducted in Cedar Valley to investigate groundwater conditions in the basin-fill aquifer (Brooks and Mason, 2005) and yielded updated estimated volumes for the groundwater budget based on a numerical simulation. Similarly, this study provided updated conceptual groundwater volumes for Parowan Valley that were used in a numerical simulation (Brooks, 2017).

\section{Purpose and Scope}

The purpose of this report is to describe the hydrology and groundwater resources of Parowan Valley and to present a revised conceptual model and budget of the groundwater flow system. This study also investigates the surface-water resources within the watersheds of five creeks that enter the valley on the east side. It discusses the relation of groundwater to surface water in Parowan Valley and presents a general water-budget analysis for the Parowan Valley groundwater system which includes the consolidated-rock aquifer to the east. It includes information on the source, occurrence, availability, quantity, movement, chemical quality, and development of the groundwater resource in the basin-fill aquifer. Emphasis is placed on refining the hydrologic concepts presented by Thomas and Taylor (1946) and Bjorklund and others (1978). Specifically, this report presents updated groundwater budgets, a new regional map of the groundwater-level surface, a new overview of groundwater [geo]chemistry/water quality in the basin-fill aquifer, and a limited assessment of interbasin flow from Parowan Valley to Cedar Valley. Water-level fluctuations and a characterization of groundwater flow paths also are described and evaluated. Surface water is described primarily as it relates to groundwater recharge and discharge. This report includes a description of groundwater recharge using the Basin Characterization Model (BCM; Flint and Flint, 2007), a recently developed distributed net-infiltration approach. Major components of groundwater discharge were re-estimated using up-to-date information on irrigation well withdrawals, land use, and water consumption by natural vegetation and crops. Environmental tracers and major-ion chemistry were used to assess groundwater recharge sources. Results of the study are intended to improve the understanding of the Parowan Valley groundwater flow system and the ability of water managers to assess the long-term sustainability of current and future groundwater supplies developed in Parowan Valley.

\section{Previous Investigations}

The earliest study of water resources in Parowan Valley was part of a larger regional reconnaissance study of western and southwestern Utah completed by Meinzer (1911). The first comprehensive study of geology and water resources in the area was completed by Thomas and Taylor (1946). This report described the water resources of Cedar and Parowan Valleys and provided information about the early stages of groundwater development in Parowan Valley. It presented a general groundwater budget and contains available water-quality, groundwater withdrawal, aquifer-property, and surface-water data. A brief description of the status of groundwater development is presented in Thomas and others (1952). Sandberg $(1963,1966)$ described the water resources of selected basins in southwestern Utah including Parowan Valley. Bjorklund and others $(1977,1978)$ also described the water resources of Cedar and Parowan Valleys. This report updated the groundwater conditions reported by Thomas and Taylor (1946) in response to declining water levels, as well as evaluated water-quality, groundwater withdrawal, aquifer-property, and surface-water data.

\section{Climate}

The climate in Parowan Valley is semi-arid and is characterized by moderate to meager precipitation, large daily temperature changes, moderately cold winters, and warm dry summers. The average annual precipitation (1981-2010) estimated from Parameter-elevation Regressions on Independent Slopes Model (PRISM) data for Parowan Valley is about 12 to 13 inches (in.) (Daly and others, 2008). The average annual precipitation in areas of the Markagunt Plateau to the east of the valley ranges from 20 to 42 in., with the highest values occurring near the town of Brian Head. Areas of the Markagunt Plateau function as headwater drainage basins for Summit, Parowan, Red, and Little Creeks. Most precipitation occurs during the winter months as snowfall and late summer months as monsoonal rainfall. Precipitation and snowpack data are typically presented for a water year (WY), which represents the period of time from October 1 to September 30 of the following year.

Two weather stations located near Parowan and Cedar City with long-term records of precipitation illustrate the variation 
in annual rainfall in the Parowan Valley study area (fig. 2). The average annual precipitation for the Parowan Power Plant station is 12.73 in. (WY1949-98). The average annual precipitation for the Cedar City Airport station is 10.83 in. (WY19492014). The Parowan Power Plant station consistently receives about 1 to 2 in. more precipitation annually than the Cedar City Airport station. This is likely a result of the greater altitude of Parowan Valley with respect to Cedar Valley. Multiple extended periods of below average precipitation (WY1974-78 and WY2006-09) and above average precipitation (WY1980 86 and WY2010-13) have been documented in the valley since 1949.

The Natural Resources Conservation Service operates three SNOTEL stations in and near the Parowan Valley study area (fig. 1). The Midway Valley SNOTEL station, located on the Markagunt Plateau about 8 mi south of Brian Head and at a similar altitude, has a long-term record of mountain precipitation, and illustrates the variation in annual precipitation in the mountains east of Parowan Valley (fig. 3). The average annual precipitation for the Midway Valley station is $36.1 \mathrm{in.}$ (WY1981-2010). Two new SNOTEL stations, Brian Head and Yankee Reservoir, which are located within the Parowan
Creek drainage basin, were installed during the summers of 2011 and 2012, respectively. The most recent annual precipitation data from these two stations are plotted in figure 3 for comparison. The Midway Valley station recorded extended periods of below average precipitation (WY1999-2004 and WY2006-10) and above average precipitation (WY1982-86) during the WY1981-2010 period.

\section{Population and Land Use}

The population of Parowan Valley is approximately 3,300 (U.S. Census Bureau, 2010), which is little more than twice the population of 1,423 reported in 1970 (Bjorklund and others, 1978). Significant growth in residential development occurred during the 1970s and the 1990s, mostly around Parowan and Paragonah. Land use within the Parowan Valley study area includes irrigated and non-irrigated farmland and pasture used for agriculture and livestock grazing; incorporated and unincorporated residential areas; and mining. The adjacent mountain areas remain mostly undeveloped and are used primarily for recreation and grazing.

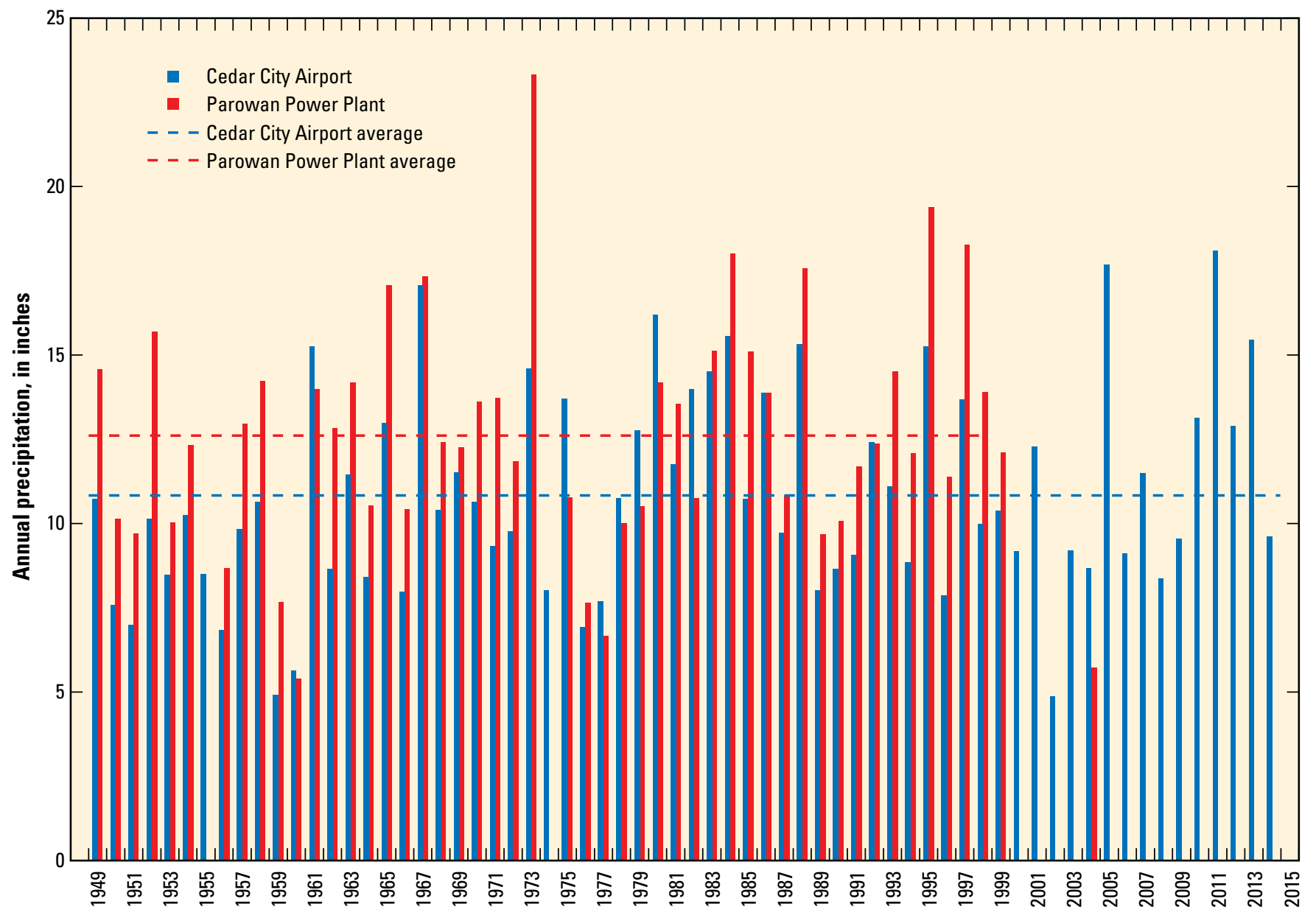

Figure 2. Long-term annual precipitation records at two weather stations in and near the Parowan Valley study area, Iron County, Utah. 


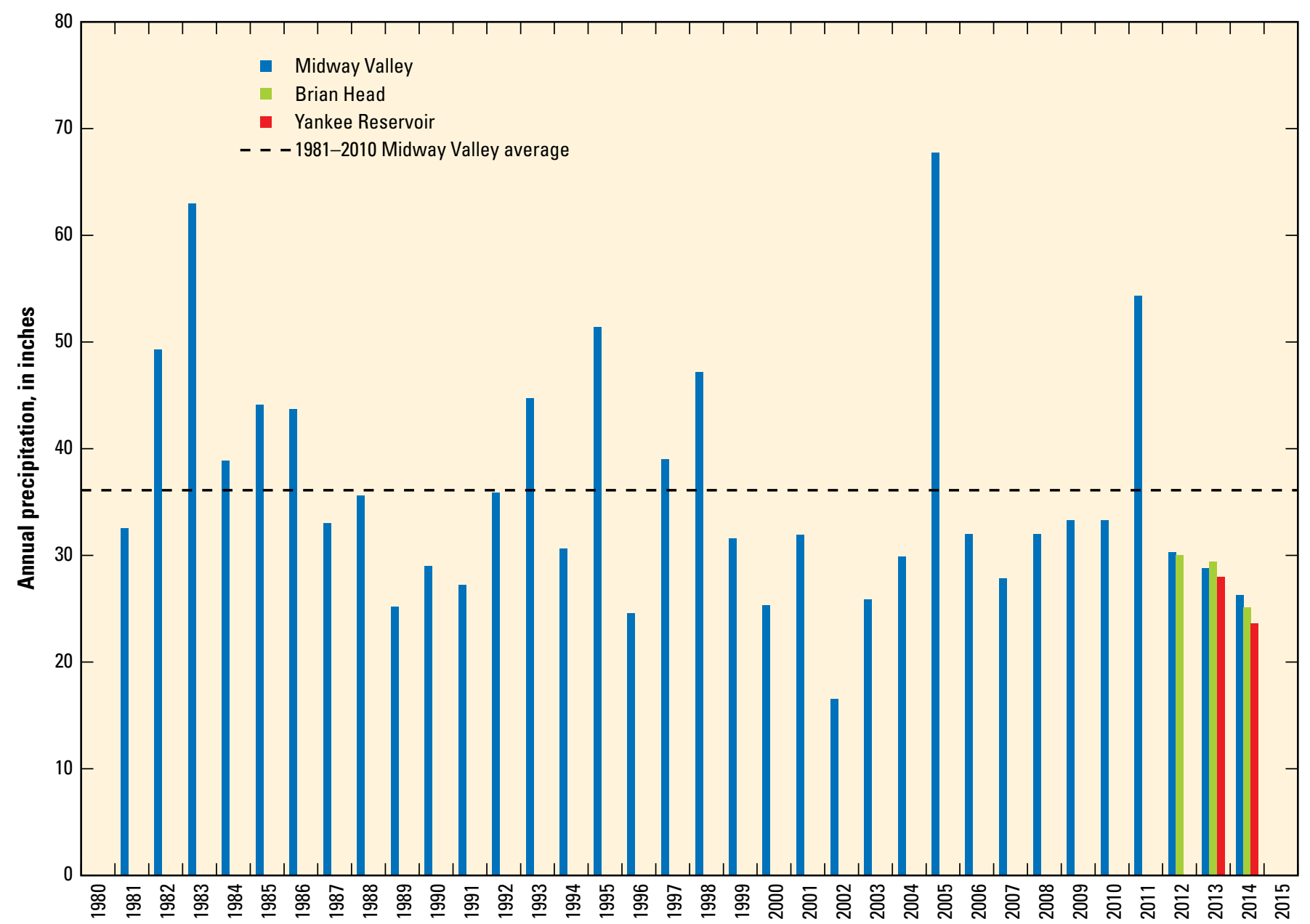

Figure 3. Annual precipitation record at three SNOTEL stations in and near the Parowan Valley study area, Iron County, Utah.

\section{Geology}

Parowan Valley lies within the Basin and Range physiographic province. The valley is separated from the plateau to the east by the Paragonah fault, which represents the regional boundary between the Colorado Plateau and Basin and Range provinces. The Paragonah fault is a normal fault with Parowan Valley occupying the downthrown hanging wall with the Red Cliffs on the foot wall.

The geologic units exposed within the study area range from Cretaceous to Quaternary in age. The Straight Cliffs Formation is the oldest formation in the lower portions of Red Canyon and Parowan Canyon. The thick sandstones and conglomerates that are visible in most of the canyons along the east side of the valley compose, from oldest to youngest, the Cretaceous Straight Cliffs, Wahweap, and Grand Castle Formations. The Cretaceous Iron Springs Formation underlies the Grand Castle Formation in the Red Hills west of Parowan Valley. These formations consist of interbedded fluvial sandstones and conglomerates. The Tertiary Claron Formation overlies the Cretaceous units east and west of the valley. The Claron is the prominent formation displayed within Cedar Breaks National
Monument and consists of mudstone, siltstone, limestone, and minor conglomerate deposited in fluvial, floodplain, and lacustrine environments of an intermountain basin bounded by Laramide uplifts (Biek and others, 2012). Numerous Tertiary and Quaternary basalt, pyroclastic, and ash flows make up the majority of the Black Mountains located to the northwest of Parowan Valley; the flows also cap formations in the high-altitude eastern parts of the study area on the Markagunt Plateau.

The Quaternary sediments of Parowan Valley include alluvium, colluvium, and alluvial fan deposits associated with the mountain streams that enter the valley on the east side, coalesced alluvial fan deposits which occupy the majority of the valley away from the steeper slopes of active alluvial fans, and Little Salt Lake playa deposits that consist of fine-grained deposits typical of an intermittent evaporative basin. The total thickness of unconsolidated basin-fill deposits in Parowan Valley is at least 2,000 ft in the south-central part of the valley just west of Parowan (Hurlow, 2002). 


\section{Surface-Water Hydrology}

Five perennial streams drain the Markagunt Plateau east of Parowan Valley, and the estimated annual streamflow during WY2013 and WY2014 (April 2013 to April 2014) measured near where they enter the valley (fig. 4) ranged from 370 to 9,900 acre-ft, resulting in a total annual streamflow of about 18,000 acre-ft (table 1). Discrete measurements of streamflow for this study began in March 2013 and ended in September 2014. The total baseflow component of streamflow from April 2013 to April 2014 for each of the five streams was estimated from periodic streamflow measurements during the winter months that were considered to be a constant baseflow rate throughout the year. High flow in Cottonwood, Little, Red, Parowan, and Summit Creeks occurs during the spring months when these streams collect runoff from melting high-altitude snowpack. All of these streams are sustained year round by groundwater discharge from mountain springs or as baseflow directly to the stream. Red and Parowan Creeks are supplemented with reservoir releases during the summer months from Red Creek Reservoir and Yankee Meadow Reservoir, respectively. During the irrigation season, which lasts from April through September, each of the named streams other than Cottonwood Creek is captured at the canyon mouth and delivered for irrigation use through a closed pipe pressurized system. Cottonwood Creek is captured at the base of the alluvial fan and stored for irrigation and stock use in a small reservoir during wet years. During average to dry years, diminished discharge from Cottonwood Creek is lost through seepage across the alluvial fan and by evapotranspiration. Except during periods of extremely high runoff, when streamflow greatly exceeds the capacity of irrigation diversions, no water from the mountain streams reaches Little Salt Lake (fig. 4).

Table 1. Annual streamflow for five streams that drain the Markagunt Plateau east of Parowan Valley, Iron County, Utah.

[acre-ft/yr, acre-feet per year; WY, water year; NA, not available; USGS, U.S. Geological Survey]

\begin{tabular}{lcccc}
\hline \multicolumn{1}{c}{ Stream name } & $\begin{array}{c}\text { Average } \\
\text { annual } \\
\text { streamflow, } \\
\text { in acre-ft/yr }\end{array}$ & $\begin{array}{c}\text { Annual } \\
\text { streamflow } \\
\text { WY2013- } \\
\text { WY2014, } \\
\text { in acre-ft/yr }\end{array}$ & $\begin{array}{c}\text { Baseflow } \\
\text { WY2013- } \\
\text { WY2014, } \\
\text { in acre-ft/yr }\end{array}$ & $\begin{array}{c}\text { Estimated } \\
\text { groundwater } \\
\text { recharge from } \\
\text { streambed } \\
\text { seepage } \\
\text { WY2013- } \\
\text { WY2014, } \\
\text { in acre-ft/yr }\end{array}$ \\
\hline Cottonwood Creek & NA & 370 & 360 & 50 \\
Little Creek & 11,400 & 1,100 & 900 & 170 \\
Red Creek & 24,800 & 4,900 & 4,500 & 250 \\
Parowan Creek & 312,000 & 9,900 & 6,000 & 540 \\
Summit Creek & 43,400 & 1,700 & 950 & 130 \\
\hline
\end{tabular}

${ }^{1}$ Average for WY1960-WY1980 at USGS Little Creek streamgage 10241400.

${ }^{2}$ Estimated based on historical measurements by USGS (Thomas and Taylor, 1946) and hydroelectric powerplant record.

${ }^{3}$ Average for WY1942-WY1950 at USGS Center Creek streamgage 10241500.

${ }^{4}$ Average for WY1964-WY1987 at USGS Summit Creek streamgage 10241600.
Three of the five mountain streams have limited periods of continuously recorded streamflow. Average annual streamflow for these streams was calculated from USGS streamgage data. Streamflow in Little Creek (USGS streamgage 10241400) was measured continuously from October 1959 through September 1980. Parowan Creek (formerly known as Center Creek, USGS streamgage 10241500) was measured continuously from October 1941 through September 1950. Summit Creek (USGS streamgage 102441600) was measured continuously from October 1963 through September 1987. Average annual streamflow for Red Creek was estimated by Thomas and Taylor (1946) and Bjorkland and others (1978) from discrete measurements made during 1938-40 and from hydroelectric power plant records during 1971-74.

\section{Periodic Discharge Measurements}

\section{Methods}

To estimate annual streamflow for the five mountain streams, periodic streamflow discharge measurements were made at each stream before it entered the valley or was diverted for irrigation. For all but Cottonwood Creek, a combination of staff plate readings for irrigation diversion structures where a stage to area-discharge relation was established, and instream wading measurements, were made on an approximately weekly interval from April 2013 through September 2014. Because Cottonwood Creek is a very small stream and does not flow through a diversion structure, it was measured three times during 2013 to evaluate peak flow and baseflow conditions. All wading measurements of discharge were made with a SonTek FlowTracker ADV (Acoustic Doppler Velocimeter), a top setting wading rod and channel width tagline. A complete description of the methods used for making a wading discharge measurement can be found in Turnipseed and Sauer (2010). Wading measurements were used to evaluate the accuracy of the staff plate readings associated with irrigation diversion structures.

Each wading discharge measurement was assigned an uncertainty estimate. The total uncertainty in a discharge measurement is a function of uncertainty in width and depth measurements, instrument uncertainty (flow velocity and direction), as well as fluctuation and unevenness in vertical flow distribution at individual measurement points across the channel. During site selection for wading measurements, channel conditions were evaluated to minimize uncertainty in the dimensional and flow components of the discharge measurement. The instrument uncertainty for a SonTek FlowTracker ADV is calculated internally as a random uncertainty through a statistical technique developed by the USGS that outputs a statistical uncertainty value as a percentage of total discharge at the completion of a measurement (Turnipseed and Sauer, 2010). 


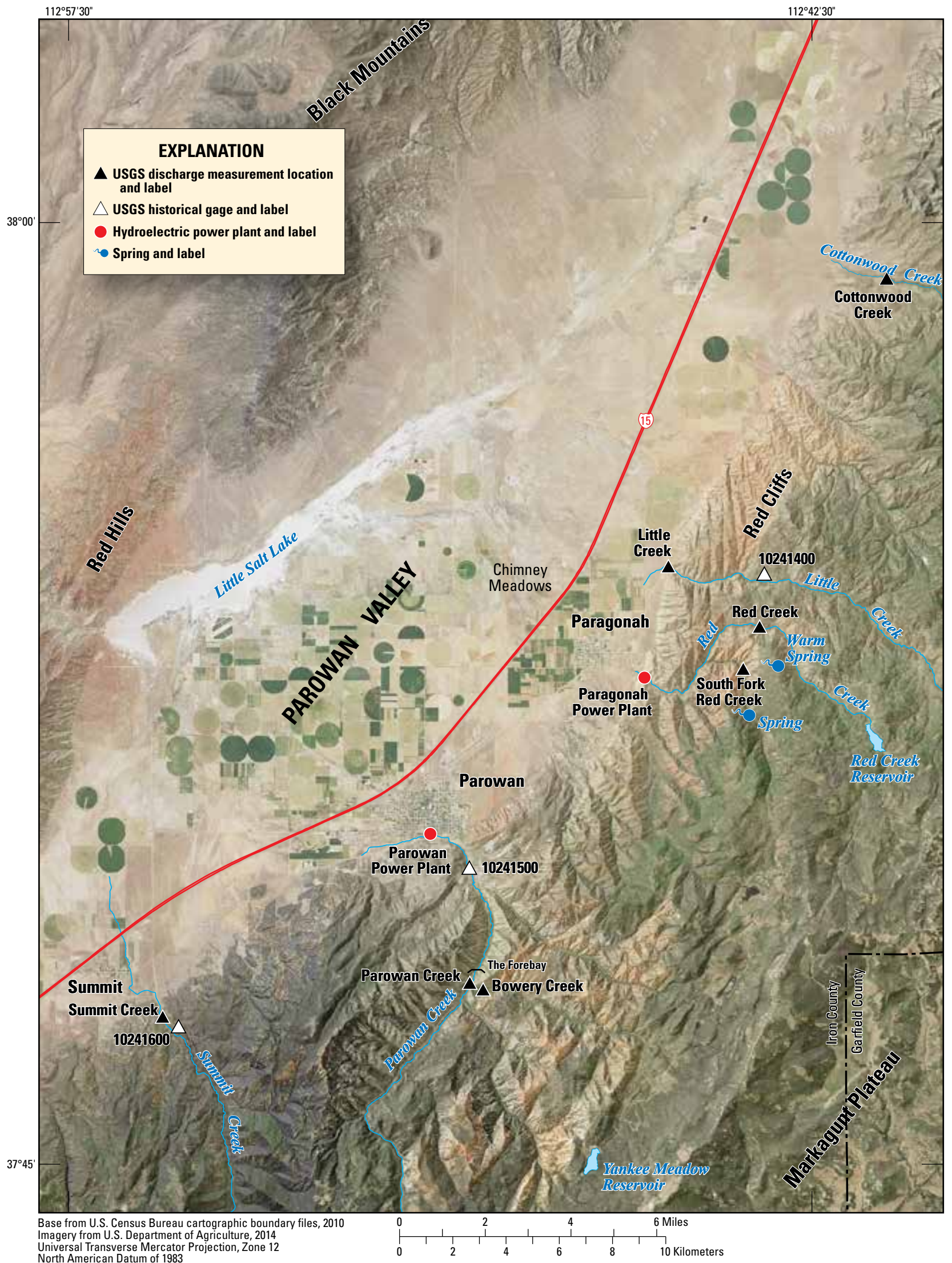

Figure 4. Locations of stream measurement sites, springs, and hydroelectric power plants within the Parowan Valley drainage area, Iron County, Utah. 


\section{Cottonwood Creek}

Cottonwood Creek is the most northern perennial stream in Parowan Valley. It is the smallest stream in the valley and accounted for less than 400 acre-ft of average streamflow from April 2013 to April 2014 (table 1). Four measurements were made during 2013 and 2014 at USGS site 375907112403001, which is located above the alluvial fan east of Parowan Valley. The drainage area above the site is approximately $10.3 \mathrm{mi}^{2}$ with an average altitude of 7,610 ft. Discharge from Cottonwood Creek ranged from 0.44 cubic feet per second $\left(\mathrm{ft}^{3} / \mathrm{s}\right)$ to $0.74 \mathrm{ft}^{3} / \mathrm{s}$ during baseflow and peak flow conditions, respectively (table 2). The cumulative discharge of 370 acre- $\mathrm{ft}$ for April 2013 to April 2014 was calculated by assuming 11 months at approximately $0.5 \mathrm{ft}^{3} / \mathrm{s}$ during baseflow and 1 month at $0.65 \mathrm{ft}^{3} / \mathrm{s}$ during peak flow. The discharge of Cottonwood Creek represents approximately 2 percent of the total surface-water discharge into Parowan Valley annually.

\section{Little Creek}

Little Creek enters Parowan Valley approximately $2 \mathrm{mi}$ northeast of Paragonah. During average to wetter than normal years, Little Creek is a perennial stream. Little Creek occasionally has no flow during late summer in drier than normal years. This condition was not observed during this study. Little Creek supplies irrigation water during the growing season to a limited number of fields located north of Paragonah and east of Interstate 15. During the winter months the stream is allowed to flow in its natural channel or over farm lands located high on the alluvial fan near the diversion structure. During December 2014, Little Creek was observed flowing in its natural channel with all discharge being lost to the stream channel approximately $0.25 \mathrm{mi}$ downstream of the mouth of the canyon.

A diversion structure utilized by local farmers for agricultural irrigation is located at the mouth of Little Creek Canyon. This structure consists of a 110-ft long concrete stilling back channel that widens from $1.5 \mathrm{ft}$ at the entrance to $18 \mathrm{ft}$ near the weir and overflow dam. The weir is oriented 90 degrees to the direction of flow at the end of the back channel and discharges south of the channel into a concrete vault that contains the distribution inlets for the pressurized irrigation system. The Little Creek weir is a 4-ft rectangular structure without end contractions (Grant and Dawson, 1995). A staff plate for periodic measurements of stage in the weir is installed near the end of the back channel and in proximity to the entrance channel of the rectangular weir. The minimum and maximum stages that can be measured at the weir are 0 and $1.60 \mathrm{ft}$, which represent 0 and $27 \mathrm{ft}^{3} / \mathrm{s}$ of discharge, respectively. 
Table 2. Discharge measurements of five streams and tributaries made during 2013 and 2014 that enter Parowan Valley, Iron County, Utah.

[USGS, U.S. Geological Survey; ID, identifier; UT, Utah; - , no data]

\begin{tabular}{|c|c|c|c|c|c|c|c|c|}
\hline Site name & USGS site ID & Latitude & Longitude & $\begin{array}{l}\text { Measurement } \\
\text { date }\end{array}$ & $\begin{array}{l}\text { Wading } \\
\text { discharge, in } \\
\text { cubic feet per } \\
\text { second }\end{array}$ & $\begin{array}{c}\text { Measurement } \\
\text { uncertainty, } \\
\text { in percent }\end{array}$ & $\begin{array}{c}\text { Weir } \\
\text { discharge, } \\
\text { in cubic } \\
\text { feet per } \\
\text { second }\end{array}$ & $\begin{array}{c}\text { Percent } \\
\text { error (wad- } \\
\text { ing/weir } \\
\text { discharge), } \\
\text { in percent }\end{array}$ \\
\hline \multirow[t]{4}{*}{ Cottonwood Creek near Paragonah, UT } & 375907112403001 & 37.9853611 & -112.6749722 & $4 / 3 / 2013$ & 0.67 & 5.7 & - & - \\
\hline & & & & $4 / 30 / 2013$ & 0.74 & 6.9 & - & - \\
\hline & & & & $11 / 15 / 2013$ & 0.44 & 9.2 & - & - \\
\hline & & & & $5 / 13 / 2014$ & 0.62 & 10.9 & - & - \\
\hline \multirow[t]{10}{*}{$\begin{array}{l}\text { Little Creek above irrigation diversion near } \\
\text { Paragonah, UT }\end{array}$} & 375432112445401 & 37.9089778 & -112.7484417 & $3 / 20 / 2013$ & 1.69 & 3.6 & - & - \\
\hline & & & & $4 / 30 / 2013$ & 2.89 & 4.6 & - & - \\
\hline & & & & $2 / 25 / 2014$ & 1.99 & 3.7 & 2.19 & 9.1 \\
\hline & & & & $4 / 1 / 2014$ & 1.59 & 6.6 & - & - \\
\hline & & & & $4 / 10 / 2014$ & 1.33 & 11.7 & 1.66 & 19.9 \\
\hline & & & & $4 / 15 / 2014$ & 1.45 & 7.3 & - & - \\
\hline & & & & $4 / 24 / 2014$ & 1.70 & 6.4 & - & - \\
\hline & & & & $4 / 30 / 2014$ & 3.00 & 4.1 & - & - \\
\hline & & & & $5 / 7 / 2014$ & 3.44 & 7.0 & 3.37 & 2.1 \\
\hline & & & & $5 / 13 / 2014$ & 2.99 & 3.5 & 2.87 & 4.2 \\
\hline \multirow[t]{4}{*}{$\begin{array}{l}\text { Red Creek above power plant diversion } \\
\text { near Paragonah, UT }\end{array}$} & 375335112430401 & 37.8929722 & -112.7177500 & $4 / 3 / 2013$ & 4.00 & 8.6 & - & - \\
\hline & & & & $4 / 30 / 2013$ & 3.32 & 3.0 & - & - \\
\hline & & & & $11 / 14 / 2013$ & 5.15 & 7.1 & ${ }^{1} 6.36$ & 15.4 \\
\hline & & & & $5 / 13 / 2014$ & 3.87 & 4.2 & ${ }^{1} 6.36$ & 22.8 \\
\hline \multirow[t]{4}{*}{ South Fork Red Creek near Paragonah, UT } & 375254112432401 & 37.8817778 & -112.7232500 & $4 / 3 / 2013$ & 1.06 & 4.6 & - & - \\
\hline & & & & $4 / 30 / 2013$ & 1.11 & 4.8 & - & - \\
\hline & & & & $11 / 14 / 2013$ & 0.23 & 10.1 & - & - \\
\hline & & & & $5 / 13 / 2014$ & 1.04 & 12.2 & - & - \\
\hline \multirow[t]{5}{*}{$\begin{array}{l}\text { Parowan Creek above Parowan diversion } \\
\text { dam near Parowan, UT }\end{array}$} & 374754112485501 & 37.7983000 & -112.8152694 & $3 / 20 / 2013$ & 8.81 & 3.9 & - & - \\
\hline & & & & $4 / 30 / 2013$ & 26.88 & 5.5 & - & - \\
\hline & & & & $11 / 14 / 2013$ & 7.43 & 2.5 & 29.85 & 1.0 \\
\hline & & & & $5 / 7 / 2014$ & 8.92 & 2.1 & - & - \\
\hline & & & & $5 / 13 / 2014$ & 10.17 & 5.7 & 211.91 & 2.9 \\
\hline \multirow[t]{4}{*}{$\begin{array}{l}\text { Bowery Creek above Parowan diversion } \\
\text { dam near Parowan, UT }\end{array}$} & 374747112483901 & 37.7965194 & -112.8107417 & $3 / 20 / 2013$ & 2.52 & 3.1 & - & - \\
\hline & & & & $4 / 30 / 2013$ & 1.93 & 5.4 & - & - \\
\hline & & & & $11 / 14 / 2013$ & 2.52 & 7.8 & - & - \\
\hline & & & & $5 / 13 / 2014$ & 2.08 & 2.2 & - & - \\
\hline \multirow[t]{9}{*}{$\begin{array}{l}\text { Summit Creek above irrigation diversion } \\
\text { near Summit, UT }\end{array}$} & 374722112550701 & 37.7893500 & -112.9185083 & $3 / 20 / 2013$ & 1.87 & 2.0 & - & - \\
\hline & & & & $4 / 30 / 2013$ & 13.99 & 2.4 & - & - \\
\hline & & & & $11 / 15 / 2013$ & 1.46 & 7.5 & 1.30 & 12.3 \\
\hline & & & & $3 / 18 / 2014$ & 1.05 & 3.2 & - & - \\
\hline & & & & $4 / 1 / 2014$ & 1.06 & 9.8 & 1.24 & 14.5 \\
\hline & & & & $4 / 15 / 2014$ & 1.83 & 4.9 & 1.93 & 5.2 \\
\hline & & & & $4 / 30 / 2014$ & 2.93 & 4.9 & 2.73 & 7.3 \\
\hline & & & & $5 / 7 / 2014$ & 2.75 & 2.3 & 2.56 & 7.4 \\
\hline & & & & $5 / 13 / 2014$ & 4.80 & 1.7 & 3.62 & 32.6 \\
\hline
\end{tabular}

\footnotetext{
${ }^{1}$ The combined flows from Red Creek (USGS Site ID 375335112430401) and South Fork Red Fleet (USGS Site ID 375254112432401) are discharged over the Red Creek weir.

${ }^{2}$ The combined flows from Parowan Creek (USGS Site ID 374754112485501) and Bowery Creek (USGS Site ID 374747112483901) are discharged over the Parowan Forebay weir.
} 


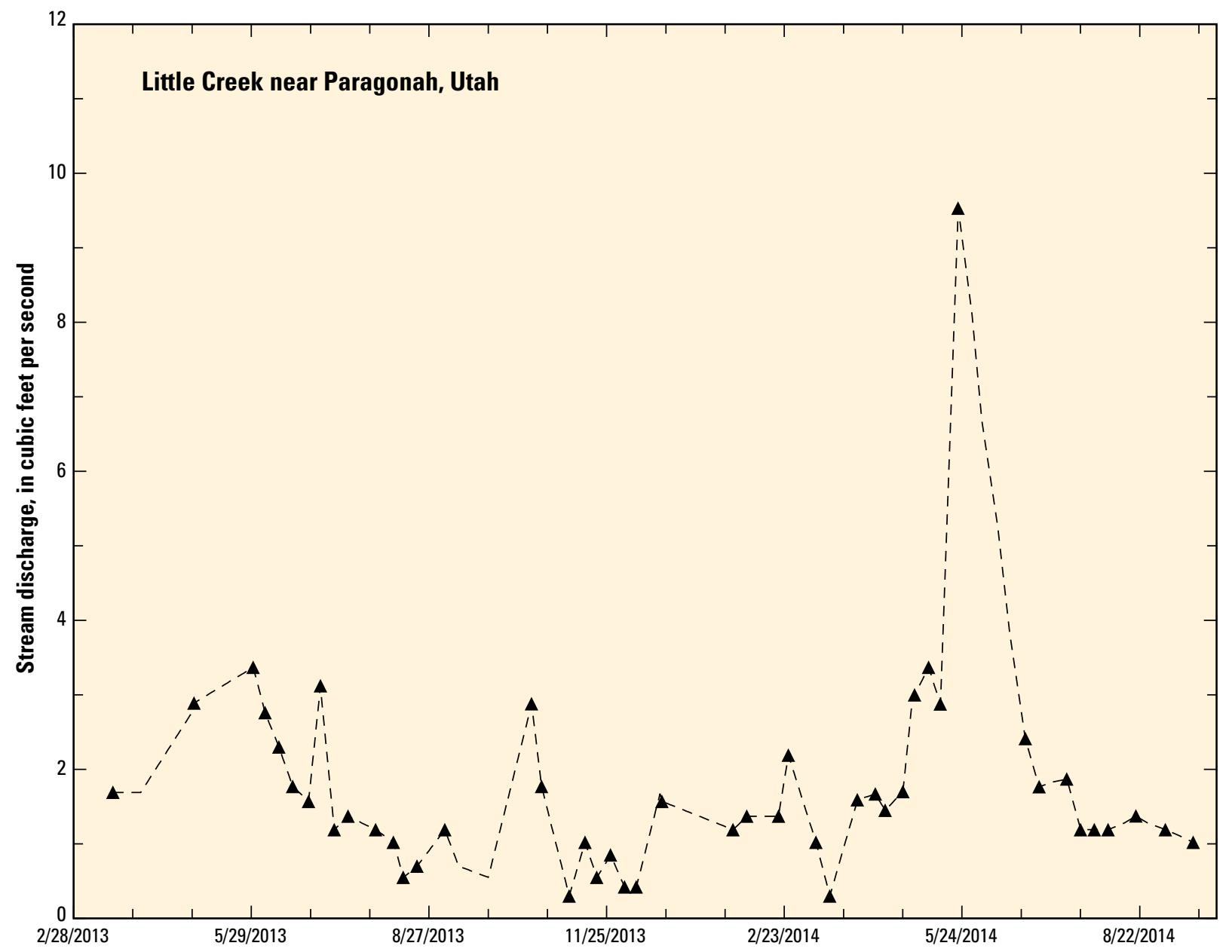

Figure 5. Discharge of Little Creek from March 2013 through September 2014, Parowan Valley, Iron County, Utah.

Weekly measurements at the weir were made by measuring stage height on a staff plate and were periodically checked with a wading measurement at USGS site 375432112445401 , located $60 \mathrm{ft}$ upstream of the concrete diversion structure containing the weir. The drainage area above the site is approximately $18.4 \mathrm{mi}^{2}$ with an average altitude of $7,840 \mathrm{ft}$. Discharge from Little Creek ranged from $0.30 \mathrm{ft}^{3} / \mathrm{s}$ to $9.5 \mathrm{ft}^{3} / \mathrm{s}$ during baseflow and peak flow conditions in 2013 and 2014 (fig. 5). Total annual discharge from Little Creek during 2013-14 was approximately 1,100 acre-ft.

\section{Red Creek}

Red Creek enters Parowan Valley approximately $1 \mathrm{mi}$ eastsoutheast of Paragonah. Red Creek is a perennial stream that is managed year round through Red Creek Reservoir, which is located high in the drainage approximately $6 \mathrm{mi}$ upstream and east of the mouth of Red Creek Canyon. Streamflow in Red Creek during the baseflow period (October-March) when Red Creek Reservoir is not releasing discharge is sustained by two springs that occur downstream of the reservoir. Two concrete diversion dams are located in Red Creek Canyon-one approximately $700 \mathrm{ft}$ downstream of Warm Spring, and the other $25 \mathrm{ft}$ downstream of a spring in the South Fork of the canyon (fig. 4). Both of the diversions supply water to the Paragonah power plant at the mouth of Red Creek Canyon through steel penstock tubes. Approximately 400 gallons per minute ( $\mathrm{gal} / \mathrm{min}$ ) of Warm Spring water is used for municipal supply in Paragonah and is diverted separately through a pipeline down Red Creek Canyon. During baseflow conditions, all of the streamflow in Red Creek and the South Fork of Red Creek can be captured by the two diversions resulting in a dry streambed below each of the diversion dams. During this study, the diversion dam in the South Fork of Red Creek was not in use, and streamflow was observed in the creek from the South Fork to the Paragonah power plant.

Water discharged from the Paragonah power plant enters a diversion structure utilized by local farmers for agricultural irrigation adjacent to the power plant. This structure consists of a 110-ft-long concrete stilling back channel that widens from $3.0 \mathrm{ft}$ at the entrance to $22 \mathrm{ft}$ at the weir. The Red Creek structure is an 11.5-ft Cipoletti weir that discharges into a concrete vault that in turn, transfers water to a retention 


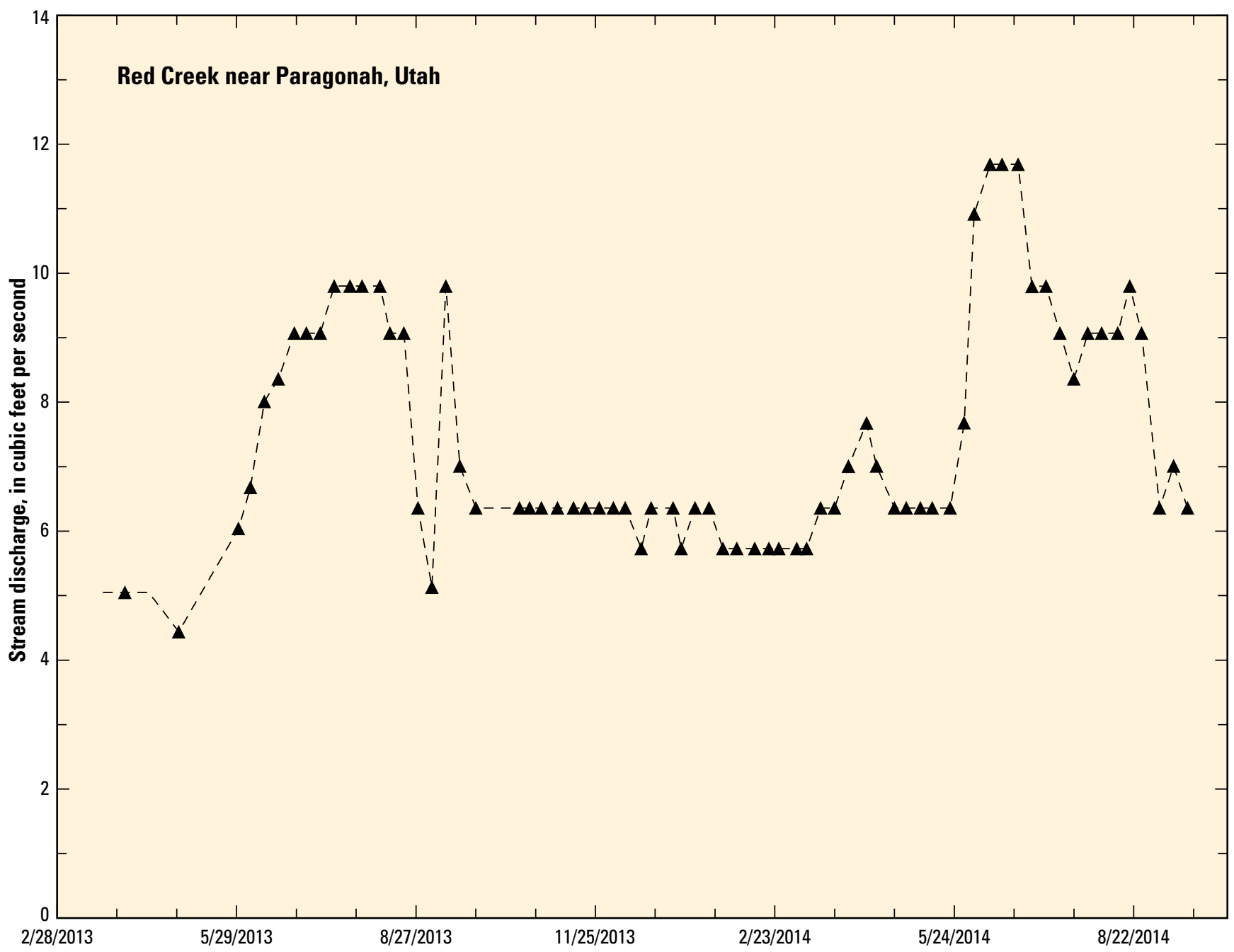

Figure 6. Discharge of Red Creek from March 2013 through September 2014, Parowan Valley, Iron County, Utah.

pond located approximately $800 \mathrm{ft}$ to the north. The retention pond contains an inlet for the pressurized irrigation system. A staff plate for periodic measurements of stage in the weir was installed near the end of the back channel in May 2013. The minimum and maximum stages that can be measured at the weir are 0 and $1.20 \mathrm{ft}$, which represent 0 and $51 \mathrm{ft}^{3} / \mathrm{s}$, respectively.

Weekly measurements were read from the staff plate at the mouth of the canyon and periodically checked with wading measurements at USGS sites 375335112430401 and 375254112432401 , located $120 \mathrm{ft}$ upstream of the concrete penstock diversion structure on Red Creek and $20 \mathrm{ft}$ downstream of the concrete penstock diversion structure on the South Fork of Red Creek, respectively. The drainage area above the power plant is approximately $18.4 \mathrm{mi}^{2}$ with an average altitude of $8,080 \mathrm{ft}$. Discharge of Red Creek ranged from $4.4 \mathrm{ft}^{3} / \mathrm{s}$ to $11.7 \mathrm{ft}^{3} / \mathrm{s}$ during baseflow and peak flow conditions in 2013 and 2014 (fig. 6). Total annual discharge from Red Creek during 2013-14 was approximately 4,900 acre-ft.

During the growing season, Red Creek supplies irrigation water to fields located north and south of Paragonah and east of Interstate 15. During the winter months, Red Creek water is transferred from the power plant through the pressurized irrigation system and discharged on the west side of Interstate 15 approximately $1 \mathrm{mi}$ northwest of Paragonah. Water from Red Creek follows a dispersed course west of Interstate 15 and is used to replenish soil moisture on forage lands near Chimney Meadows during winter months. Red Creek only flows in its natural channel across the alluvial fan and into the valley during large spring runoff and flash flood events.

\section{Parowan Creek}

Parowan Creek enters Parowan Valley approximately 0.5 mi southeast of Parowan. Parowan Creek is a perennial stream that is partly managed year round through Yankee Meadow Reservoir, which is located high in the Bowery Creek (a tributary of Parowan Creek) drainage approximately $9.5 \mathrm{mi}$ upstream and southeast of the mouth of Parowan Canyon (fig. 4). Baseflow in Parowan Creek during October-March when Yankee Meadow Reservoir is not releasing water, is 


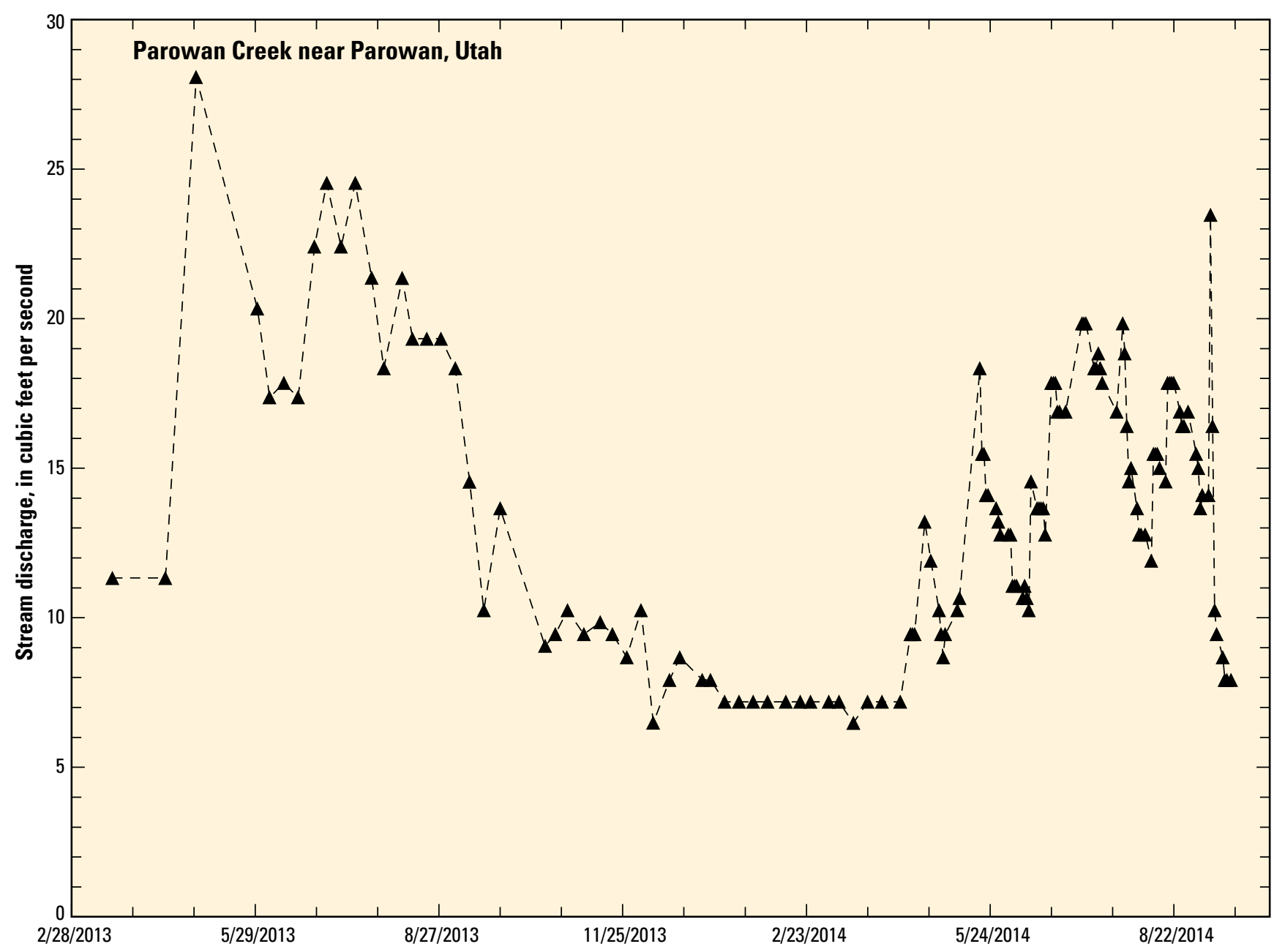

Figure 7. Discharge of Parowan Creek from March 2013 through September 2014, Parowan Valley, Iron County, Utah.

sustained by multiple springs and gaining reaches of the streams that occur in the drainage.

One concrete diversion dam, known as the Forebay, is located below the confluence of Parowan Creek and Bowery Creek (fig. 4). This diversion supplies water to the Parowan power plant located within the town of Parowan through a steel penstock tube. The diversion also supplies secondary water to users in and around Parowan. During baseflow conditions, all of the streamflow in Parowan Creek can be captured by the diversion resulting in a dry streambed below the Forebay diversion dam. During this study, the penstock for the Parowan power plant was not in use due to repairs. Parowan Creek was observed flowing in its natural channel until a secondary concrete diversion located near the power plant captured the water for agriculture.

The Forebay diversion dam consists of a 13-ft Cipoletti weir and bypass gate atop a small concrete dam that is approximately $45 \mathrm{ft}$ long. The small reservoir retained behind the Forebay occupies the natural confluence of Parowan Creek and Bowery Creek. A suspended staff plate is located near the weir. Water that discharges over the weir enters a concrete vault that can transfer the water to a retention pond located approximately $100 \mathrm{ft}$ to the east and also is the origination point for the power plant penstock. The retention pond contains the inlet for the secondary irrigation system for Parowan. The minimum and maximum stages that can be measured at the weir are 0 and $1.20 \mathrm{ft}$, which represent 0 and $58 \mathrm{ft}^{3} / \mathrm{s}$, respectively.

Weekly measurements were read from the staff plate and periodically checked with wading measurements at USGS sites 374754112485501 and 374747112483901 , located approximately $180 \mathrm{ft}$ upstream of the Forebay dam along Parowan Creek and 0.3 mi. upstream of the Forebay along Bowery Creek. The drainage area above the Forebay is approximately $48.1 \mathrm{mi}^{2}$ with an average altitude of $8,830 \mathrm{ft}$. Discharge of Parowan Creek ranged from $6.5 \mathrm{ft}^{3} / \mathrm{s}$ to $28.1 \mathrm{ft}^{3} / \mathrm{s}$ during baseflow and peak flow conditions in 2013 and 2014 (fig. 7). Total annual discharge from Parowan Creek during 2013-14 was approximately 9,900 acre-ft.

Parowan Creek supplies irrigation water to a limited number of fields located west and south of Parowan during the growing season. Water discharged from the Parowan power plant enters a distribution structure utilized by local farmers for agricultural irrigation adjacent to the power plant. This 


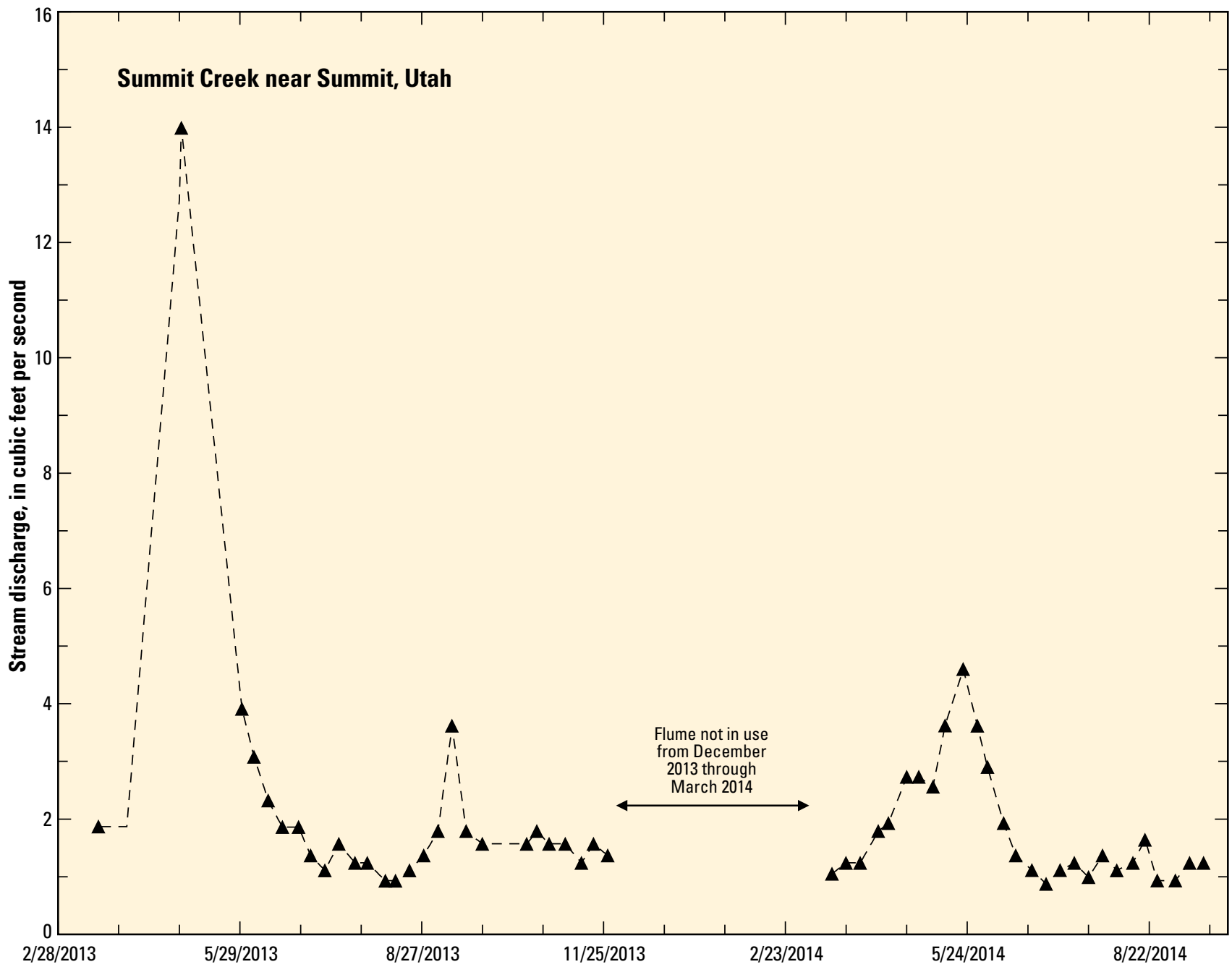

Figure 8. Discharge of Summit Creek from March 2013 through September 2014, Parowan Valley, Iron County, Utah.

structure splits the water into three pressurized irrigation systems for the north fields, center fields, and south fields. During the winter months, Parowan Creek is routed to two ponds, which are both located west of Parowan and slightly outside the town. Parowan Creek only flows in its natural channel below the power plant during large spring runoff and flash flood events.

\section{Summit Creek}

Summit Creek enters Parowan Valley approximately $1 \mathrm{mi}$ southeast of Summit. Summit Creek supplies irrigation water to a limited number of fields located west of Summit during the growing season. During the winter months, the creek is allowed to flow in its natural channel to a gravel pit or over lands located high on the alluvial fan near the diversion structure. During December 2014, Summit Creek was observed flowing over farm lands south of Summit.

A diversion structure utilized by local farmers for agricultural irrigation is located at the mouth of Summit Creek
Canyon. This structure consists of a 120 -ft-long stilling back channel that widens from $6 \mathrm{ft}$ at the entrance to $15 \mathrm{ft}$ near the flume and overflow dam. The flume is oriented 90 degrees to the direction of flow at the end of the back channel and discharges into a pipe north of the channel that transfers the water to a retention pond located approximately $500 \mathrm{ft}$ north of the flume. The Summit Creek Parshall flume is a 2-ft-wide concrete structure (Grant and Dawson, 1995). A staff plate for periodic measurements of stage is installed in the flume. The minimum and maximum stages that can be measured are 0 and $2.54 \mathrm{ft}$, which represent 0 and $34 \mathrm{ft}^{3} / \mathrm{s}$, respectively.

Weekly measurements were read from the staff plate and periodically checked with a wading measurement at USGS site 374722112550701 , located approximately 0.4 mi upstream of the diversion structure. The drainage area above the site is approximately $24.1 \mathrm{mi}^{2}$ with an average altitude of $8,410 \mathrm{ft}$. Discharge of Summit Creek ranged from $0.88 \mathrm{ft}^{3} / \mathrm{s}$ to $14 \mathrm{ft}^{3} / \mathrm{s}$ during baseflow and peak flow conditions in 2013 and 2014 (fig. 8). Total annual discharge from Summit Creek during 2013-14 was approximately 1,700 acre-ft. 


\section{Groundwater Hydrology}

Groundwater is the primary source for drinking water and agricultural irrigation and stock watering in Parowan Valley. The productive unconsolidated basin-fill aquifer is present throughout the valley. The majority of the wells in the study area are completed in the basin-fill deposits because of ease of drilling, location, and proximity to populated areas. Two wells are known to be completed in bedrock units. These wells are municipal supply wells for Parowan and Cedar City, and are located near the eastern and southern boundaries of the valley.

Parowan Valley is conceptualized as a single, interconnected hydrologic system where recharge that occurs through consolidated rock in the mountains can enter and move through the adjoining basin-fill deposits in the valley. In this conceptualization, groundwater withdrawn from the basin-fill aquifer downgradient of recharge areas is replenished by the storage available from the adjoining consolidated-rock aquifer, which in turn, is recharged by annual in-place infiltration from primarily winter precipitation. The consolidated-rock aquifer is also the source for baseflow in mountain streams and springs. Generally, groundwater movement is from north to south in the northern part of the valley, and from east to west in the central and southern parts of the valley. The general direction of groundwater movement in the valley is toward the historical discharge zone associated with Little Salt Lake.

\section{Aquifer Properties}

Aquifer properties describe the ability of a groundwater system to transmit and store water. The distribution of these properties in Parowan Valley is variable and depends on the depositional environment of sediments in the basin-fill aquifer. Aquifer properties can be estimated with aquifer tests by pumping groundwater from a well and monitoring the waterlevel changes in the pumped well and (or) in nearby observation wells. Aquifer test data are commonly used to estimate values of transmissivity, hydraulic conductivity, and storativity or the storage coefficient. Both transmissivity and hydraulic conductivity describe the ease with which water can move through the pore space within an aquifer. More specifically, hydraulic conductivity is the volume of water flowing through a unit cross-sectional area of an aquifer under a unit hydraulic gradient in a given amount of time, and transmissivity is the volume of water flowing through a cross-sectional area that is one unit wide multiplied by the aquifer thickness in a given amount of time. The storage coefficient is the volume of water released from storage per unit decline in hydraulic head (water level) in the aquifer (Freeze and Cherry, 1979).

There were no aquifer tests conducted during this study; however, four aquifer tests were conducted in Parowan Valley during 1974-75 (Bjorkland and others, 1978). The wells that were pumped and observed were located along the length of the valley with one located in the northern part of the valley, one in the central part of the valley, and two in the south-central part of the valley. The test conducted at a well in the northern part of the valley (C-32-8)12bac-1, yielded hydraulic-conductivity values from 476 to 700 feet per day $(\mathrm{ft} / \mathrm{d})$ and transmissivity values from 102,000 to 677,000 square feet per day $\left(\mathrm{ft}^{2} / \mathrm{d}\right)$ from six observation wells. The storage coefficient estimated from the test ranged from 0.0007 to 0.014 . During this test, drawdown was observed at observation wells located 3,060 and 9,000 ft from the pumping well after 5 and 160 minutes, respectively. Tests conducted at wells in the central and south-central parts of the valley yielded hydraulic-conductivity values from 21 to $37 \mathrm{ft} / \mathrm{d}$ with transmissivity values from 1,400 to $17,900 \mathrm{ft}^{2} / \mathrm{d}$. The storage coefficient estimated from these tests ranged from 0.00007 to 0.02 . During these tests a similar response to pumping was observed in adjacent wells located between 600 and 1,000 ft from the pumping well with drawdown occurring within 5 minutes after pumping commenced (Bjorkland and others, 1978, table 4).

Well log data indicate that most wells in Parowan Valley produce groundwater from discrete layers or lenses of coarsegrained materials in the basin fill. These coarse-grained zones may be the buried remnants of older fluvial channels associated with the alluvial fans that occupy much of the valley. Well log data from wells located on the Red Creek and Little Creek alluvial fans, as well as many wells located in the Chimney Meadows area and in the southern part of Buckhorn Flat, show a thick clay layer extending from land surface down to about 50 to $250 \mathrm{ft}$. This clay layer likely contributes to the confined conditions in the aquifer that produced many flowing wells throughout the north-central part of Parowan Valley historically. Interbedded clay and gravel layers are observed in the majority of well logs in the valley. Well log data from wells located in the northern part of the valley indicate that water-producing layers are dominated by volcanic debris and volcanic sands.

\section{Occurrence and Movement of Groundwater}

Sources of groundwater in Parowan Valley occur in both unconsolidated basin-fill and consolidated-rock aquifers under confined and unconfined conditions. Within the basin fill, unconfined conditions generally exist along the margins of the valley within the upper portions of the alluvial fans; confined conditions generally exist in the central parts of the valley. Groundwater moves more rapidly under confined conditions where fluvial deposits contain zones of permeable material mixed with semi-continuous to continuous layers of low-permeability clay or silt. Although unconfined groundwater movement occurs within most bedrock mountain areas, structural features and variations in lithology likely result in localized areas of confined conditions.

Groundwater moves from high-altitude recharge areas toward low-altitude discharge areas. In Parowan Valley the majority of the recharge occurs to the east on the Markagunt Plateau and enters the basin-fill aquifer through subsurface flow, infiltration from mountain streams as they cross alluvial fan deposits, and from irrigation of agricultural fields. A 
water-level map for the basin-fill aquifer in Parowan Valley and the basin-fill aquifer in the northern part of Cedar Valley near the town of Enoch was constructed from water-level measurements made at approximately 100 wells during November 2012 and 2013 (fig. 9 and table 3). Parowan Valley is conceptualized as a predominantly closed basin groundwater system with groundwater movement toward historical discharge areas around Little Salt Lake (Thomas and Taylor, 1946). Water levels in a small southern portion of the valley near the town of Summit indicate there is likely a groundwater divide that extends from near Summit northwest across the valley to the Red Hills (fig. 9). In areas that are located southwest of the divide, water levels indicate a flow gradient toward Enoch and Cedar Valley.

Groundwater flow directions in the valley have remained generally unchanged from those mapped in 1974 (Bjorkland and others, 1978, pl. 6). Overall, water levels have dropped by approximately $20 \mathrm{ft}$ for the entire valley since 1974, and locally more in areas where groundwater withdrawals are high. The highest groundwater altitudes in the basin-fill

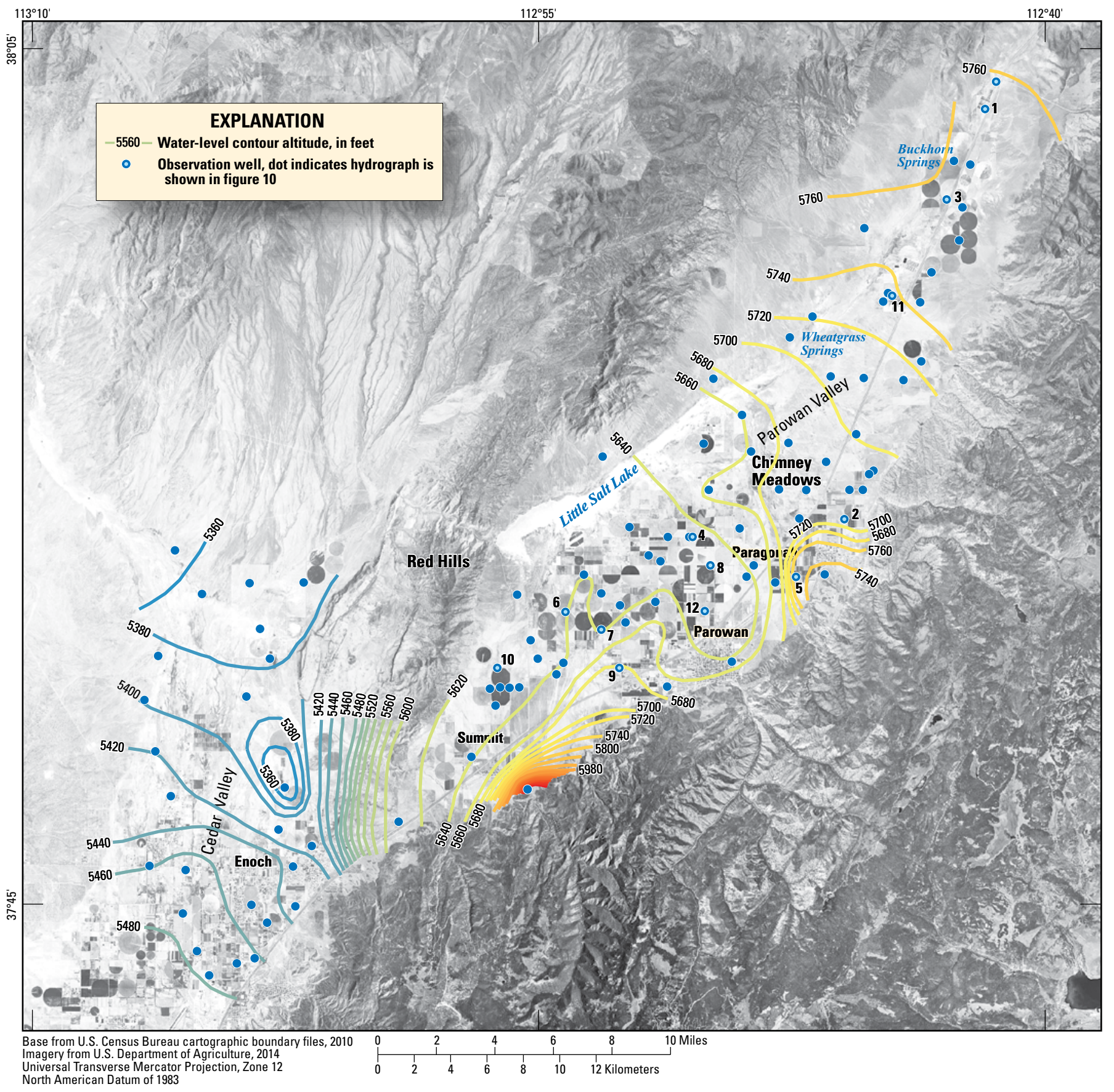

Figure 9. Regional groundwater-level contour map for the basin-fill aquifer in November 2013, Parowan Valley and northern Cedar Valley, Iron County, Utah. 


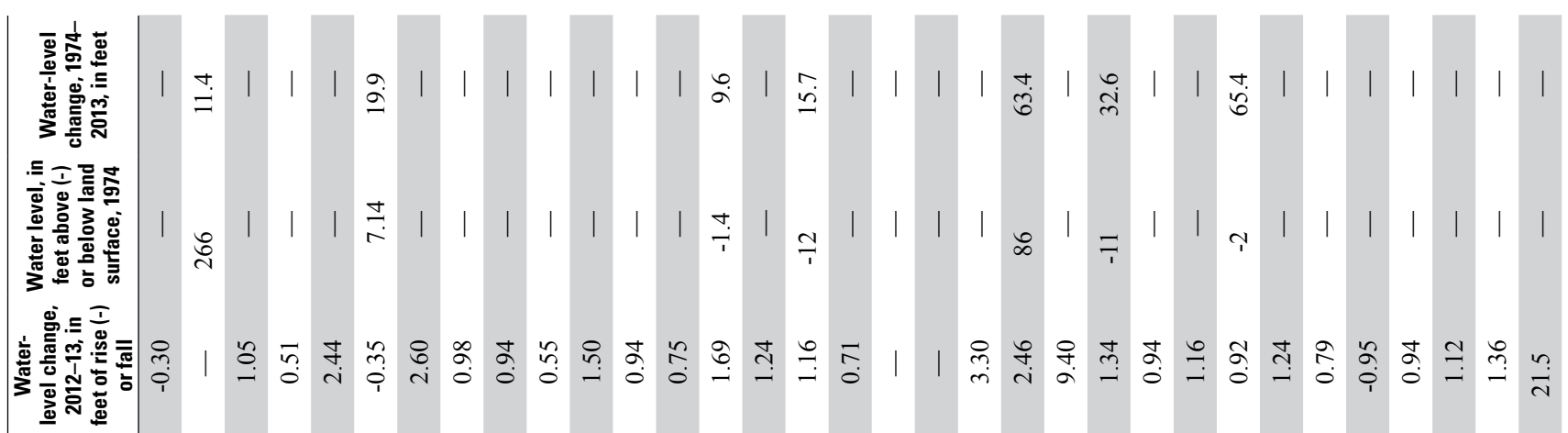

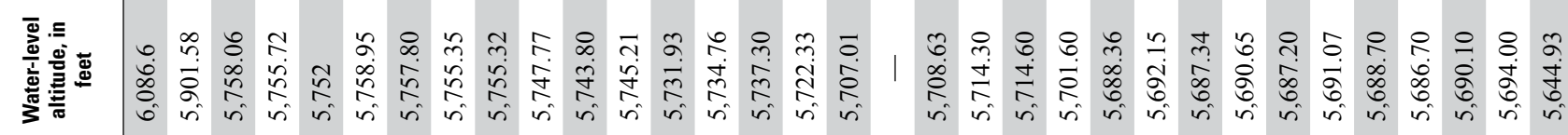

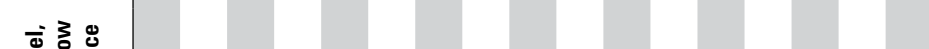

(1)

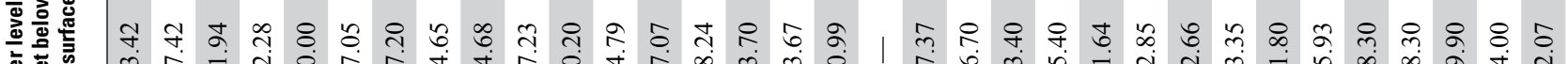

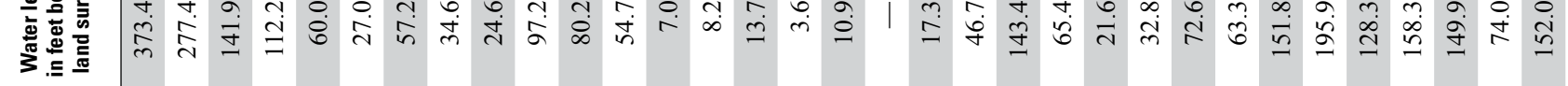

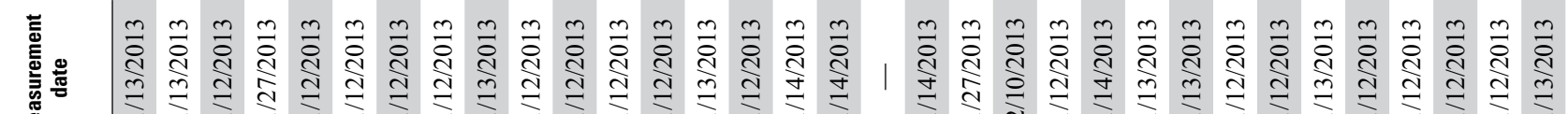

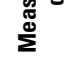

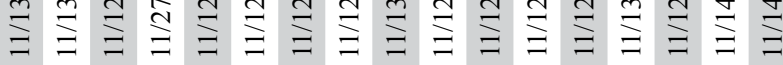

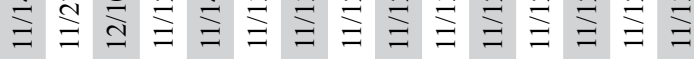

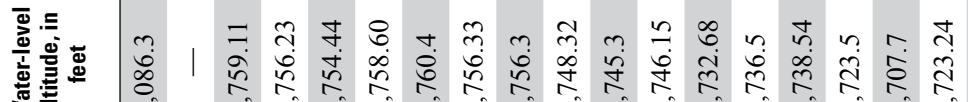
要焉

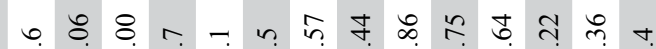

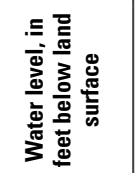

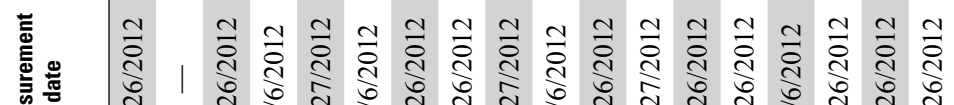

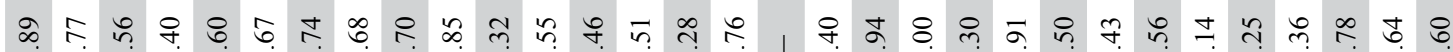

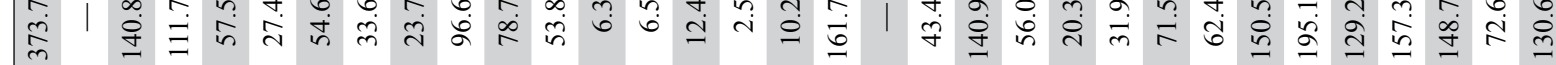

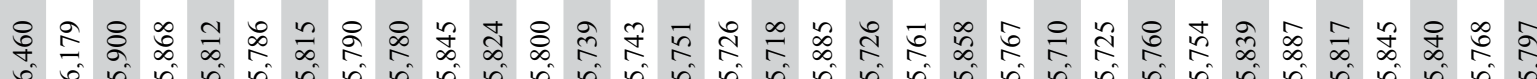

它

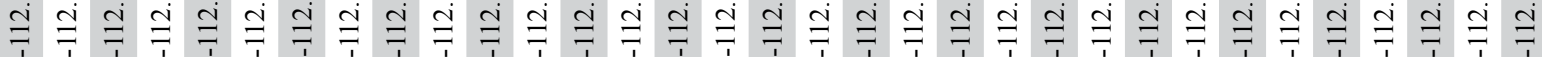

西

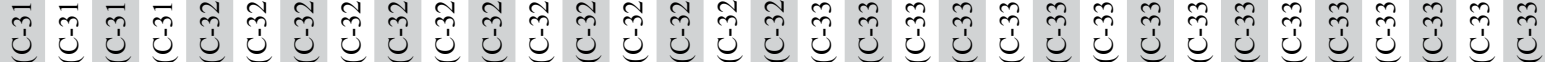




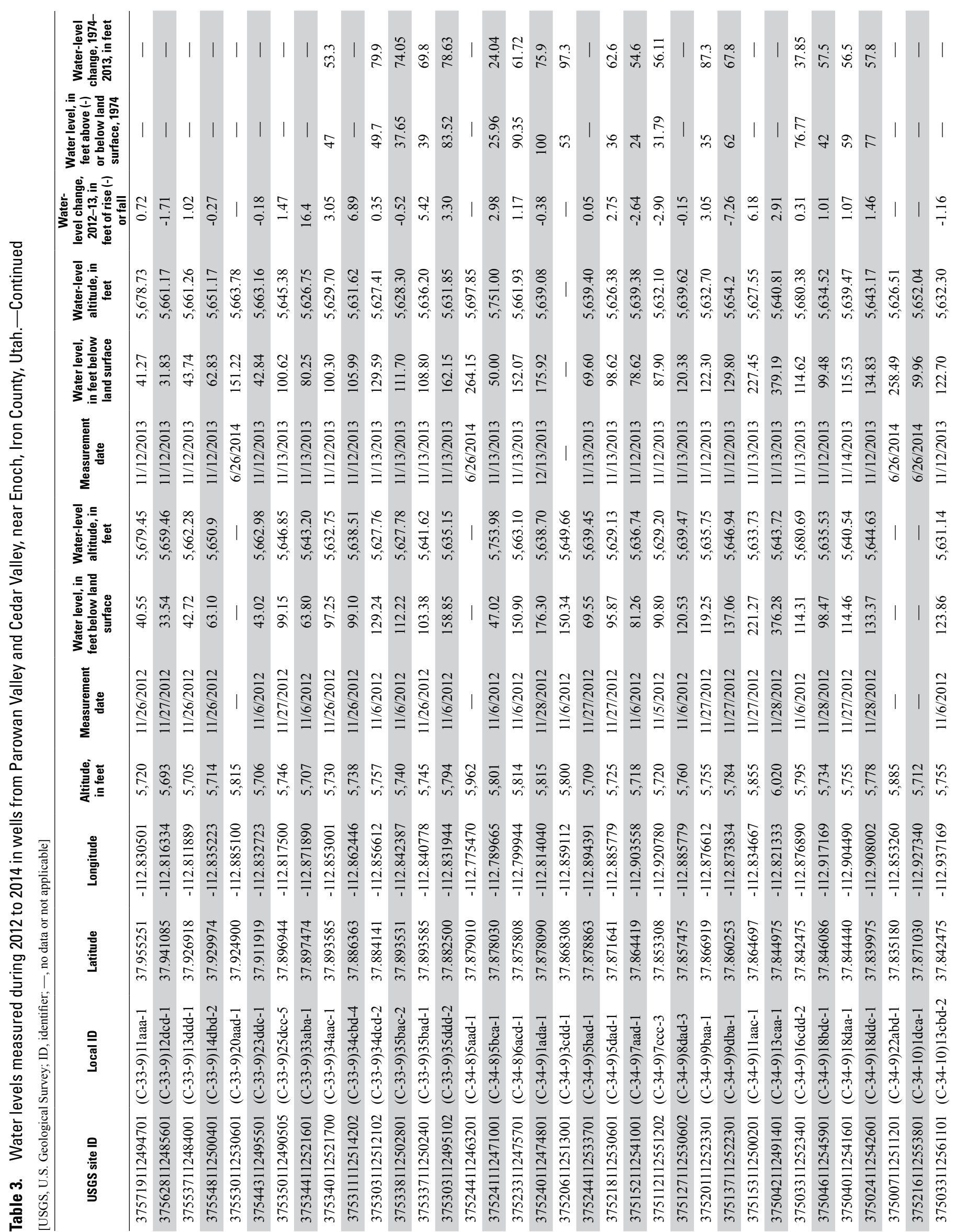




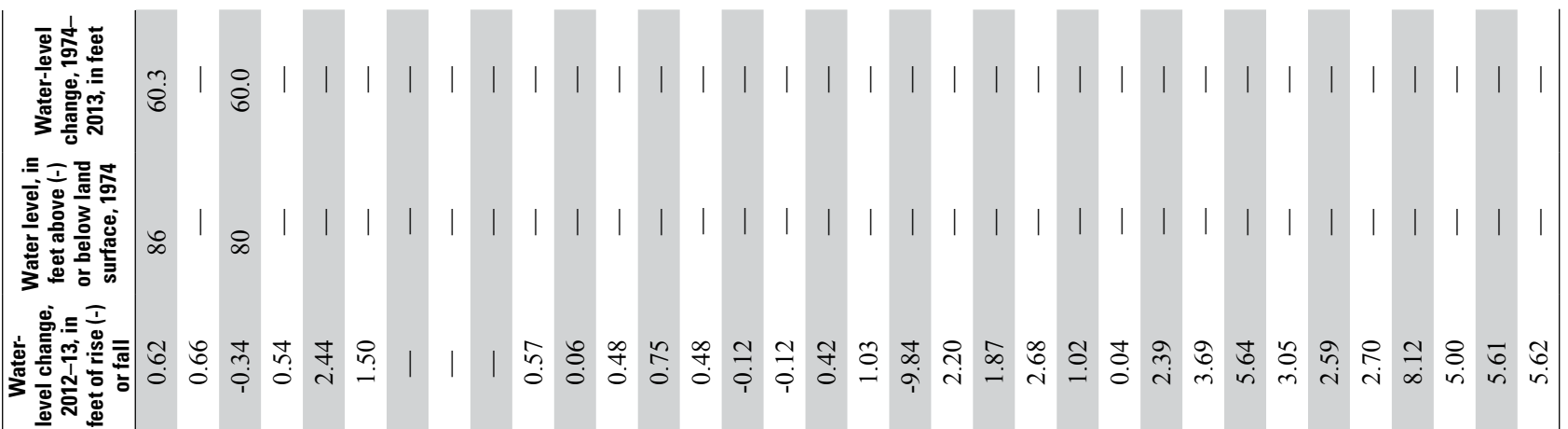

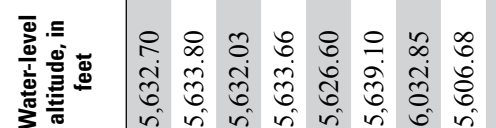

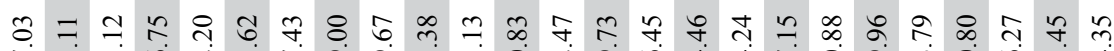

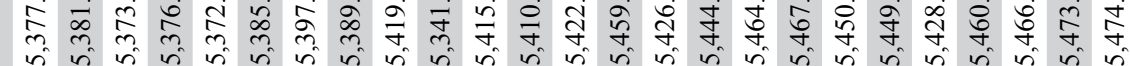

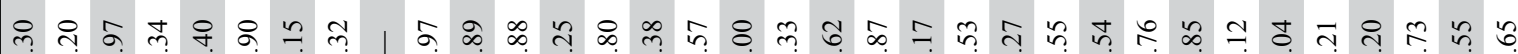
守

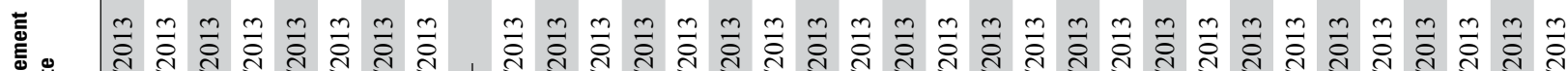

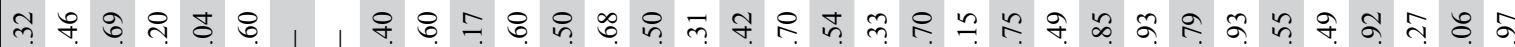

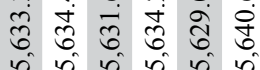

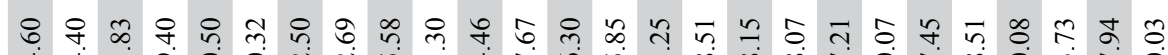
要焉

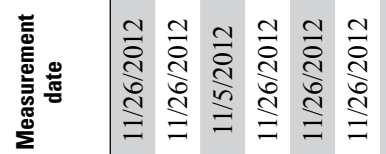

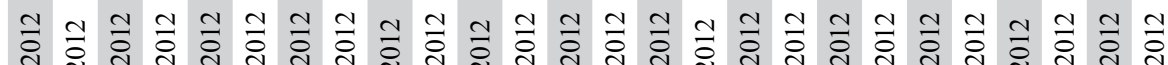

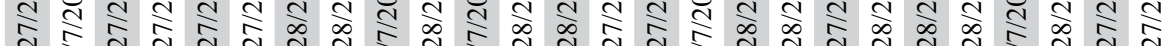
$\exists=\exists \exists$

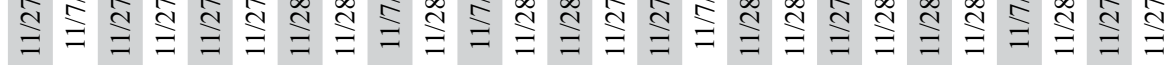

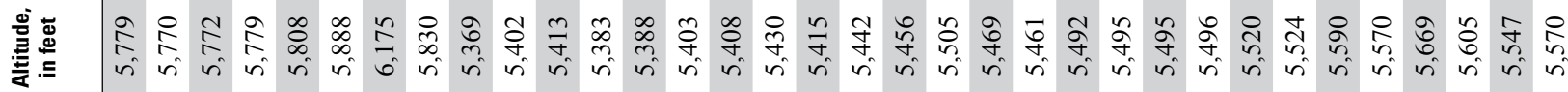
\&

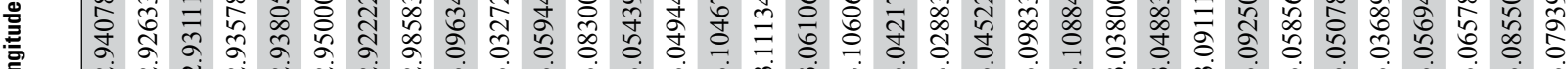

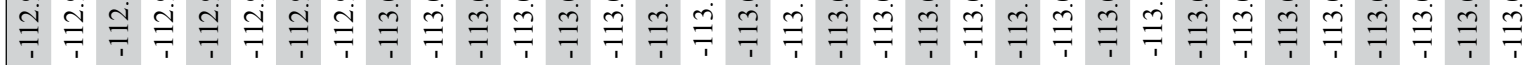

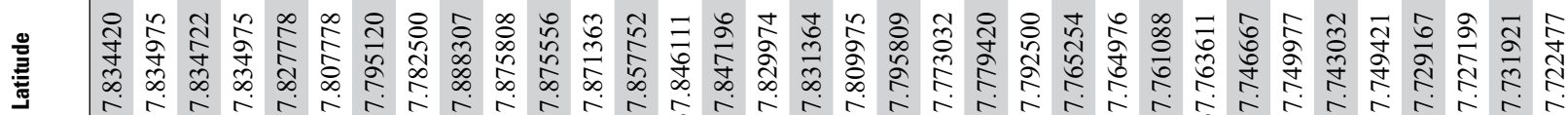

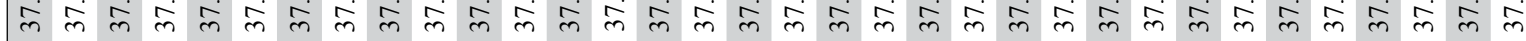

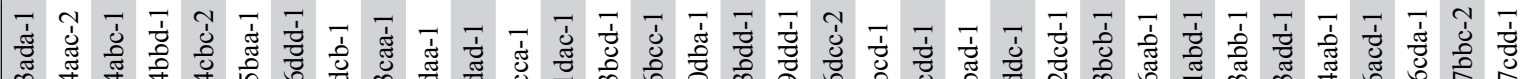


aquifer in 2013 occurred in the most northern part of the valley, near the mouth of Red Creek, and near the mouth of Summit Creek (fig. 9). The lowest groundwater altitudes occurred in the center of the valley east of Little Salt Lake.

In the northern part of the valley, groundwater moves southwestward from recharge areas on the Markagunt Plateau and from highlands located north of the valley near the divide between the Parowan Valley drainage and the Beaver Valley drainage (fig. 9). Because the Black Mountains, located to the west of the northern part of Parowan Valley, receive much less annual precipitation than the Markagunt Plateau, it is assumed that they contribute a substantially lesser amount of groundwater inflow to the valley. Groundwater continues to move southwestward through Buckhorn Flat toward Little Salt Lake.

In the central part of the valley, groundwater moves westward from recharge areas on the Markagunt Plateau and from recharge from stream losses that occur as Little Creek and Red Creek enter the valley. Confined conditions dominate this part of the aquifer; this part of the valley historically had a high percentage of flowing wells as well as numerous springs. Most of the springs were located just west of Paragonah. The land extending from Paragonah north and west to the Little Salt Lake is known as Chimney Meadows because of the numerous historical flowing wells (Thomas and Taylor, 1946). No flowing wells were observed during this study, indicating that groundwater levels have declined to below land surface since that time. The shallowest water levels within this area are now found near Wheatgrass Springs, which were observed to be dry during this study. In November 2013, the water level at a shallow well located in the historical spring discharge area was $3 \mathrm{ft}$ below land surface.

In the southern part of the valley, groundwater moves northwestward from recharge areas on the Markagunt Plateau and from recharge from stream losses that occur as Parowan Creek and Summit Creek enter the valley (fig. 9). Although the water-level surface map indicates that groundwater movement is toward Cedar Valley at the south end of Parowan Valley, drillers' logs from wells in that area indicate shallowing of basin-fill sediments underlain by consolidated volcanic-rock lithologies. The transmissivity of the consolidated rocks in the southern part of the valley is unknown. The hydraulic gradient between Parowan and Cedar Valleys is locally high where the basin-fill aquifer thins, and could indicate a low-permeability boundary between the two valleys.

\section{Water-Level Fluctuations}

Water levels in wells fluctuate in response to imbalances between groundwater recharge and discharge. Water levels rise when recharge exceeds discharge for a period of time and decline when the opposite occurs. Variations in recharge and discharge are driven by natural and anthropogenic (humaninduced) processes, such as annual variability in precipitation and groundwater withdrawals for irrigation. Long-term waterlevel fluctuations in Parowan Valley are presented in Burden and others (2015) for 12 wells where repeated measurements have been made for various periods of time to illustrate the response of the groundwater system to long-term variations in recharge and discharge (fig. 10). The long-term water-level data for these wells (two have more than 70 years of record) were filtered to include only early spring water-level measurements for each year. All water-level data are available through the USGS National Water Information System (NWIS) database (http://waterdata.usgs.gov/nwis). The wells with longterm water-level data are completed in the basin-fill aquifer. In all 12 wells, water levels have generally declined since about the mid-1950s. Wells in the northern part of the valley have seen less total decline than wells in the southern part of the valley, but have recently been declining more rapidly due to increases in pumping in the northern part of the valley.

A 1-yr water-level change map was constructed from differences in water levels measured in approximately 100 wells in November 2012 and November 2013 (fig. 11). On the basis of measurements in 2013, water levels in Parowan Valley have decreased by at least $1 \mathrm{ft}$ in most of the valley from water levels measured in 2012. In the area west and northwest of Parowan, where irrigation pumping is most abundant and concentrated, water-level declines were greater than $5 \mathrm{ft}$ in 1 year. The greatest declines were observed in the area northwest of Parowan toward Little Salt Lake. Declines of greater than $2 \mathrm{ft}$ were observed in wells near agricultural lands located along the mountain front between Cottonwood Creek and Little Creek, and in the northern part of the valley. 


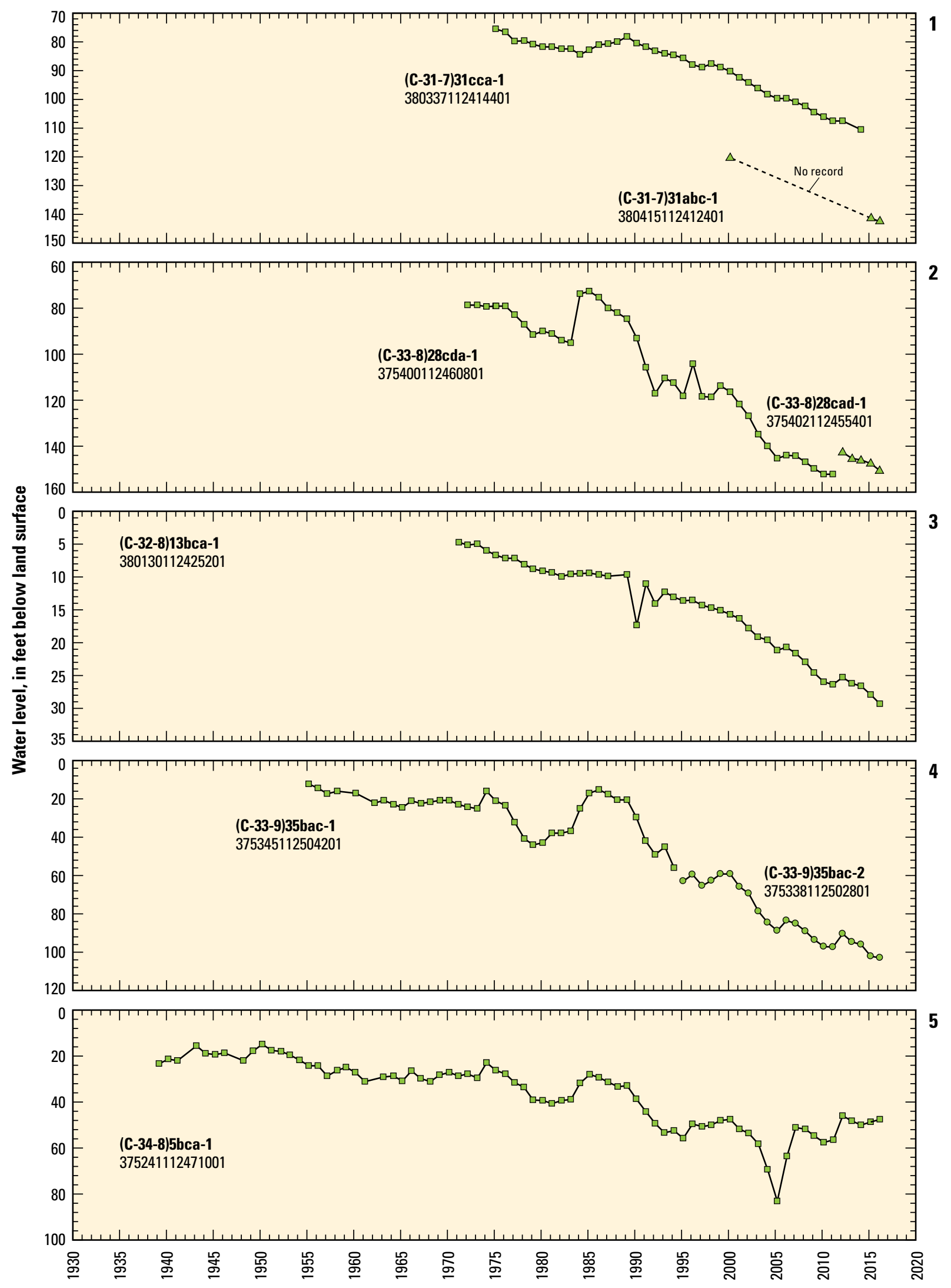

Figure 10. Long-term water-level fluctuations in selected wells in Parowan Valley, Iron County, Utah. 


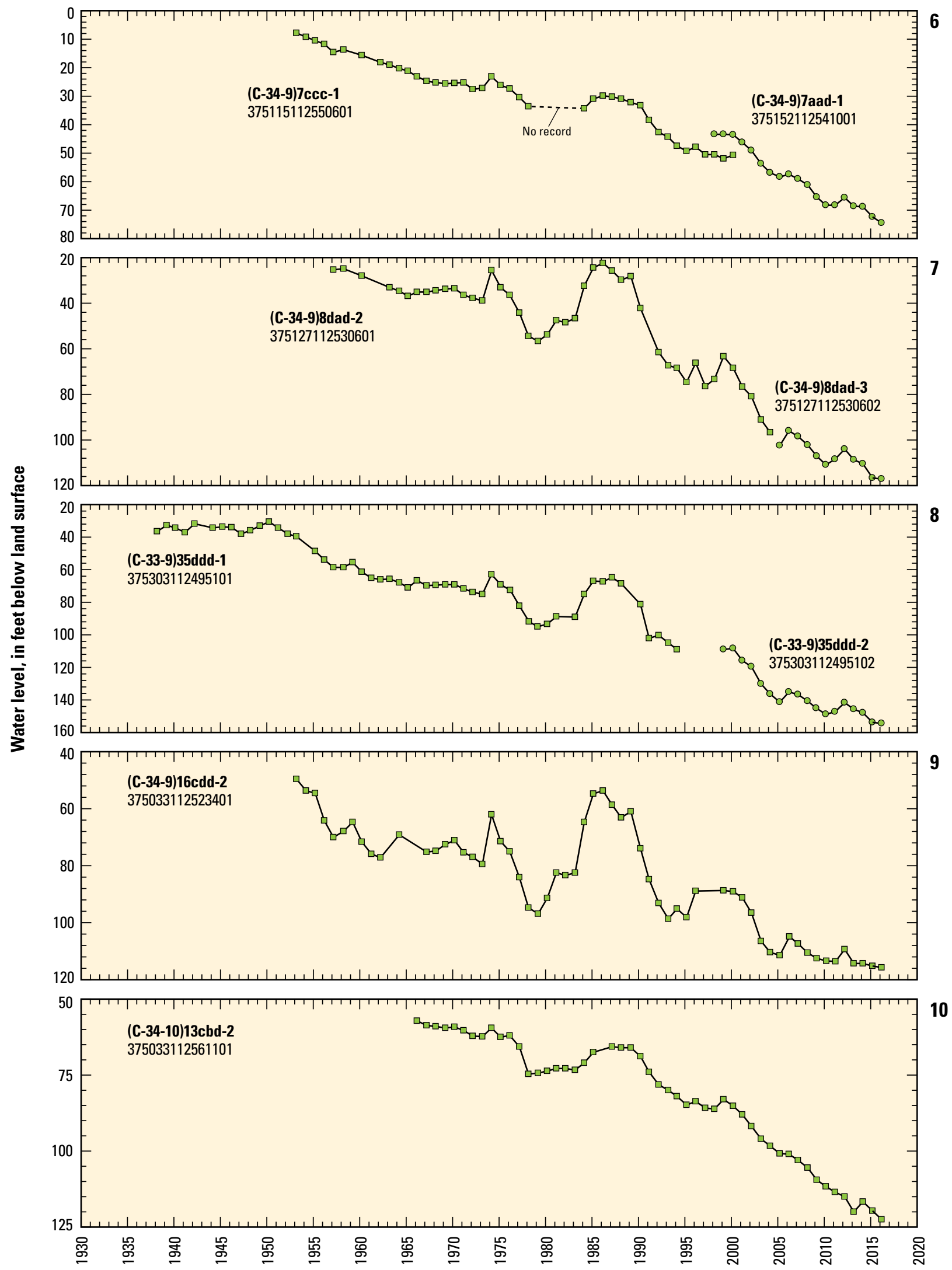

Figure 10. Long-term water-level fluctuations in selected wells in Parowan Valley, Iron County, Utah.-Continued 


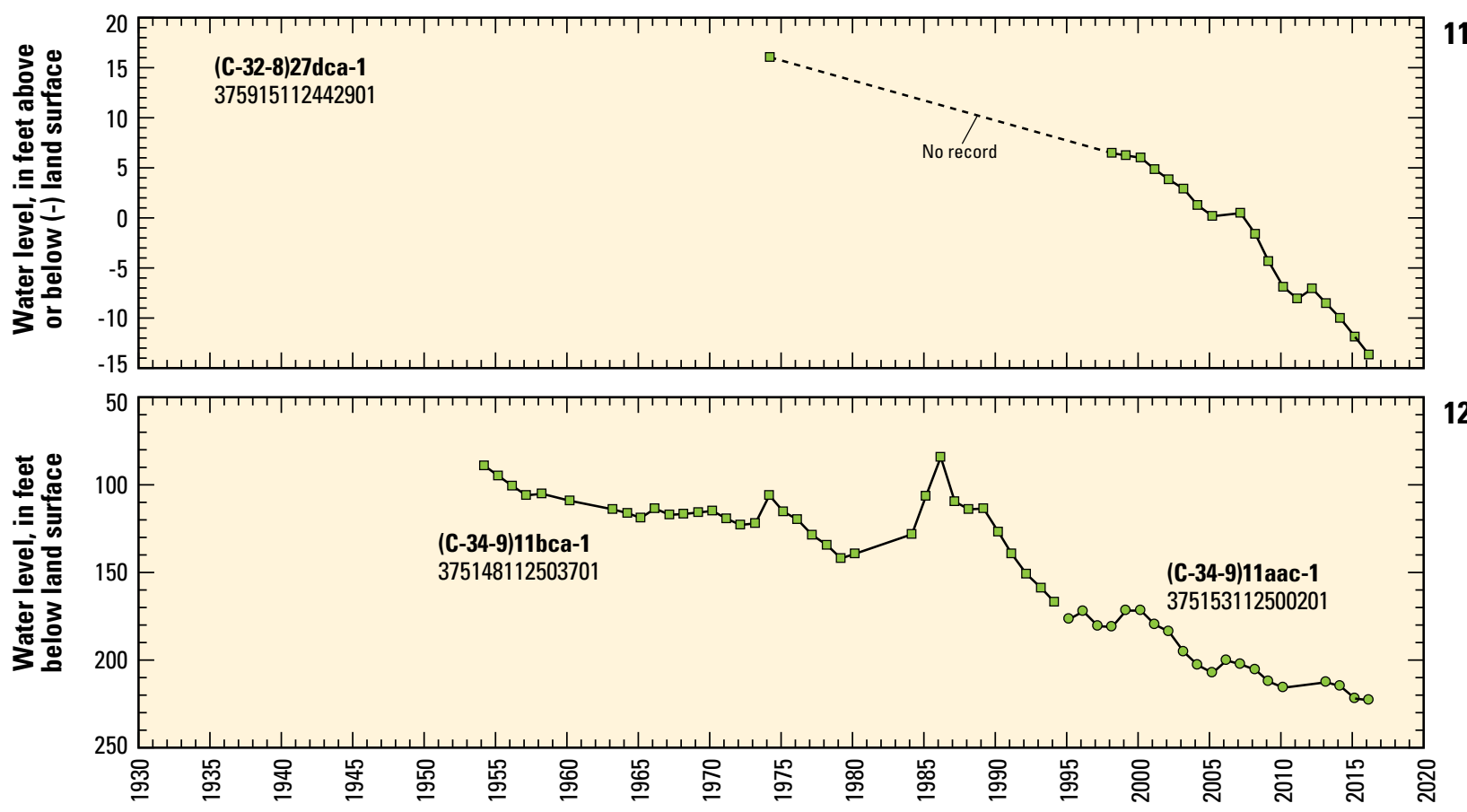

Figure 10. Long-term water-level fluctuations in selected wells in Parowan Valley, Iron County, Utah.—Continued

During this study, many of the wells used to produce the water-level change maps in 1974 (Bjorklund and others, 1978) were visited to establish a new long-term water-level change map that would illustrate changes to the groundwater system since 1974. In some areas like Chimney Meadows where flowing wells were abundant in 1974, water levels were above land surface, and the height of the water level above land surface for those wells was estimated. The current water-level change map is dashed due to the uncertainty of change for the wells located in the Chimney Meadows area (fig. 12). On the basis of the water levels measured in November 2013, most of the water levels in Parowan Valley have decreased by at least $20 \mathrm{ft}$ in the last 39 years. The average decline in water levels in the northern part of valley from 1974 to 2013 was about 20 to $30 \mathrm{ft}$, while the average decline in water levels in the southern and central parts of the valley was about $50 \mathrm{ft}$ (fig. 12). In areas where irrigation pumping is more focused, water-level declines from 1974 to 2013 were about $90 \mathrm{ft}$. The area northwest of Parowan toward Little Salt Lake where most of the agricultural fields and the highest density of wells in the valley are located is where the greatest declines are found. 


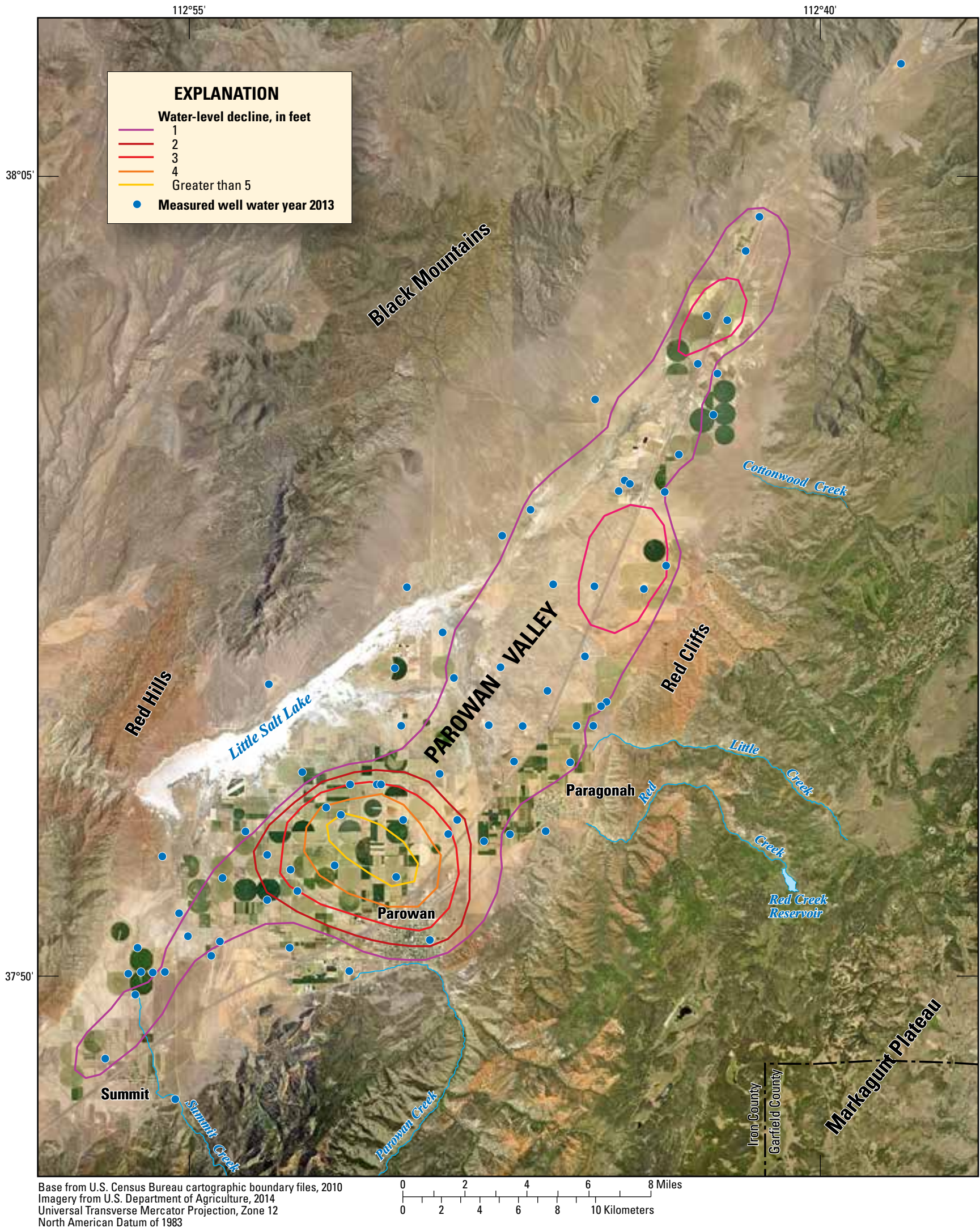

Figure 11. Water-level change in the basin-fill aquifer from November 2012 to November 2013, Parowan Valley, Iron County, Utah. 


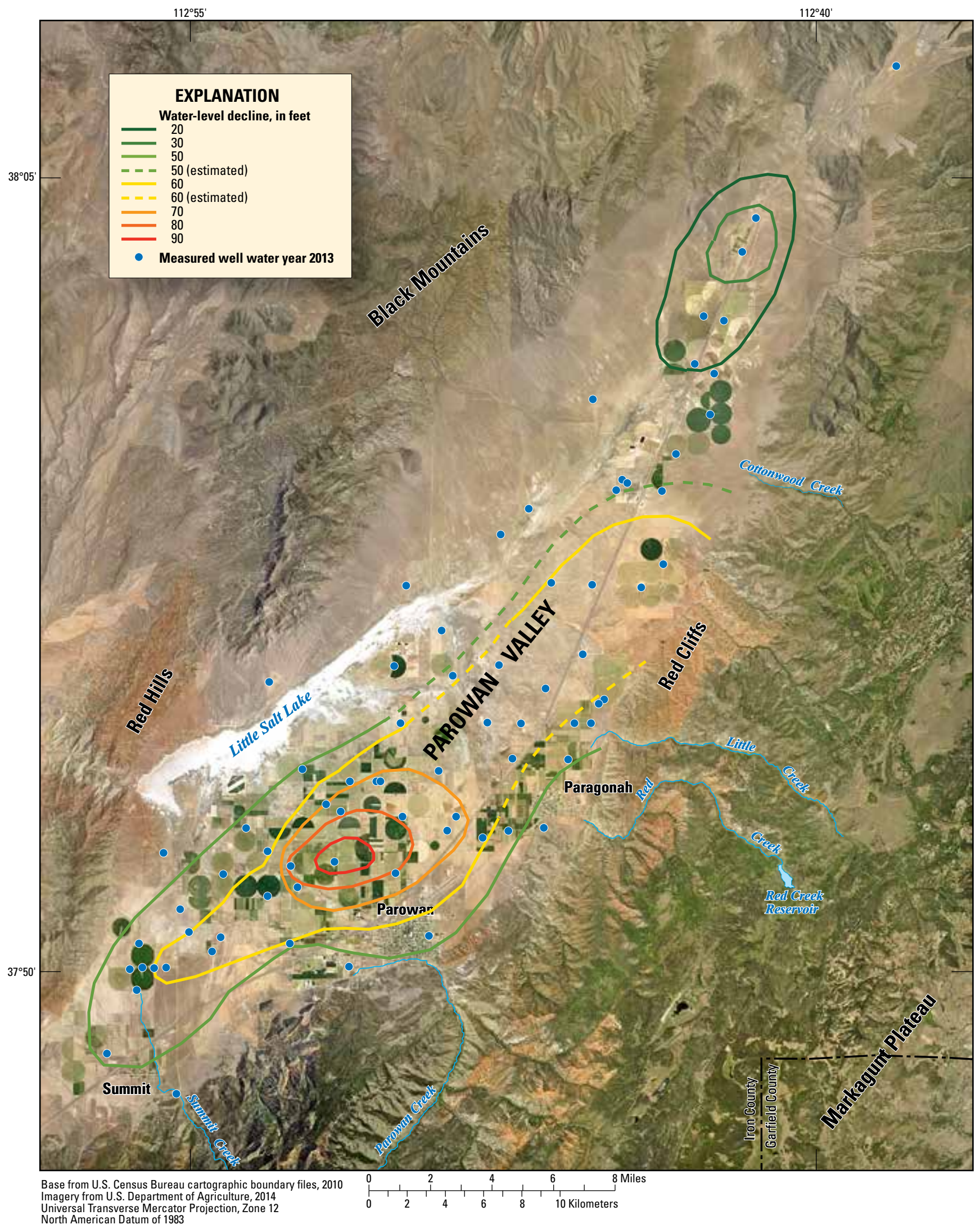

Figure 12. Water-level change in the basin-fill aquifer from 1974 to 2013, Parowan Valley, Iron County, Utah. 


\section{Groundwater Budget}

The groundwater budget presented here is compiled from estimates of recharge to and discharge from the Parowan Valley groundwater system. Although measurements of individual budget components vary in uncertainty, the budget is intended to estimate conditions that were present from 1994 to 2013. Budget components for years prior to 2013 are included to examine the variability of the groundwater system and its response to fluctuations in those components. This groundwater budget represents a combination of the consolidated-rock aquifer that is present in the surrounding mountains as well as the basin-fill aquifer where groundwater is being used extensively as a resource (fig. 13).
Infiltration of mountain precipitation is the component of recharge that enters the groundwater system at the highest altitude. A portion of the mountain recharge moves through shallow parts of the adjacent consolidated-rock aquifer and into the valley's basin-fill aquifer in the subsurface. Another portion of the mountain recharge supports the baseflow component of flow in mountain streams. The total annual streamflow consists of baseflow and runoff, with runoff reaching its peak amount in late spring. Because the mountain streams are captured and diverted during runoff (as discussed in the "Surface-Water Hydrology" section of this report), the runoff component of streamflow will not be considered as a component of the groundwater budget. During the summer, all of the streamflow that would have entered the valley is captured and

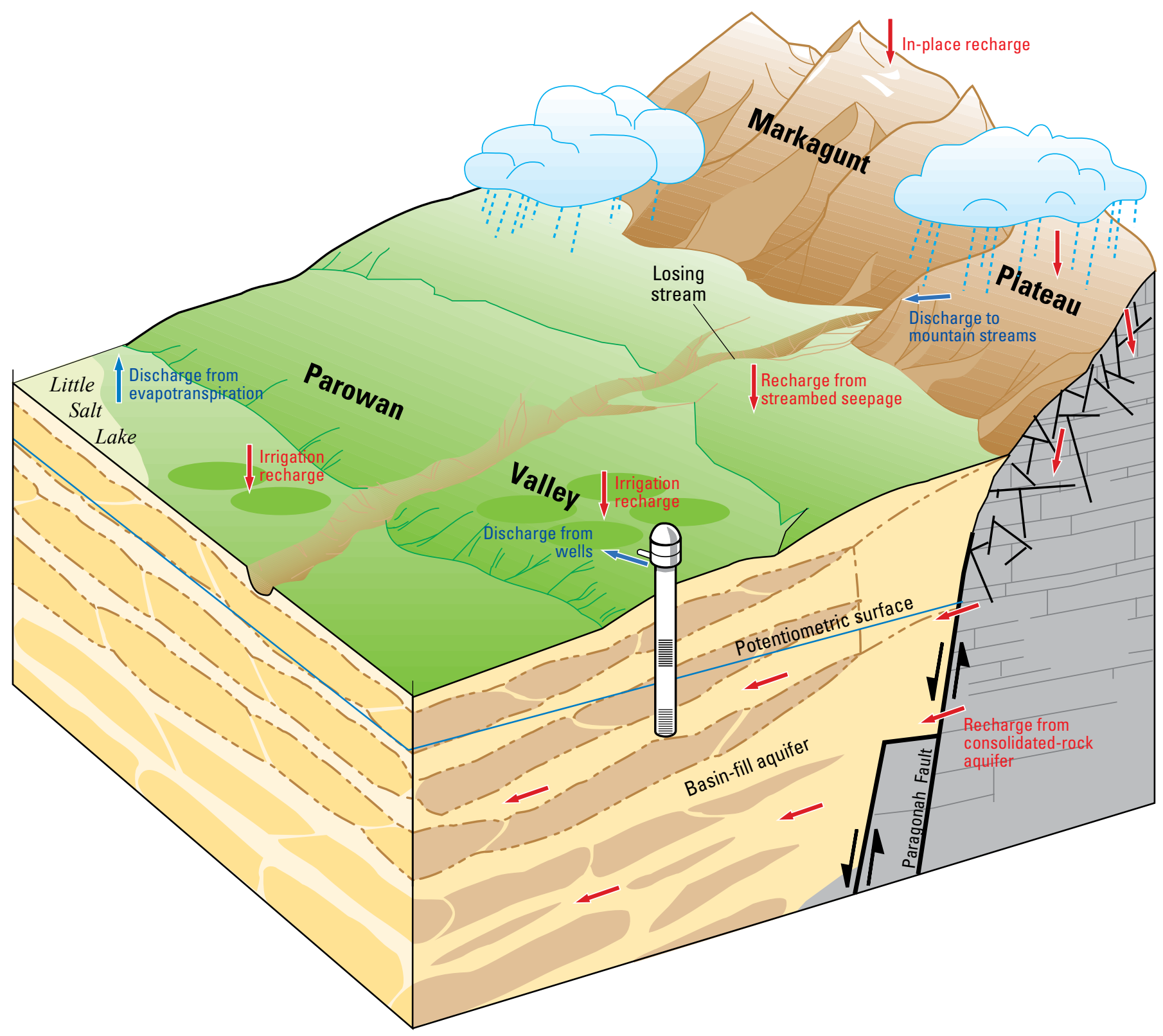

Figure 13. Conceptualized hydrologic setting and groundwater system in the Parowan Valley study area, Iron County, Utah. 
distributed as water for agricultural irrigation through pressurized systems. A fraction of the irrigation water is lost to seepage, which becomes aquifer recharge.

The groundwater budget presented in table 4 lists components of the Parowan Valley groundwater-flow system. Recharge to the Markagunt Plateau and discharge from Parowan Valley in 2013 were approximately 11,800 and 32,200 acre-feet (acre-ft), respectively. The average recharge (1994 through 2013) to the Markagunt Plateau and discharge from Parowan Valley were approximately 24,800 and 32,200 acre-ft, respectively. Most of the recharge to the groundwater system occurs as precipitation on the Markagunt Plateau east of Parowan Valley. The valley basin-fill aquifer receives most recharge directly from the consolidated-rock aquifer in the subsurface, with less originating from streambed seepage across alluvial fans and irrigation recharge from agricultural fields. Almost all of the discharge that occurs in the valley is by pumping of irrigation wells during the summer months. Groundwater evapotranspiration makes up a very small portion of the total discharge in the groundwater budget.

The groundwater budget shows that groundwater storage was depleted by about 26,800 acre-ft in 2013 (table 4), compared to the average depletion (1994 through 2013) of about 15,100 acre-ft. The greater depletion in 2013 reflects a basin-wide imbalance caused by below average in-place recharge during 2013 due to a below average snowpack (fig. 3), which results in a high percentage of groundwater being removed from storage. The long-term declines in water levels indicate the groundwater system is consistently in a state of imbalance.

\section{Recharge}

Recharge to the Parowan Valley groundwater system is almost entirely by direct infiltration of snowmelt and rainfall that occurs in the mountains east of Parowan Valley. The amount and distribution of recharge affect water levels and groundwater movement throughout much of the basin-fill aquifer. A smaller amount of recharge occurs from infiltration of irrigation water and from seepage of mountain streams that cross high-permeability areas located on the higher-altitude parts of alluvial fans.

Table 4. Groundwater budget from 1994 through 2013 for Parowan Valley, Iron County, Utah.

\begin{tabular}{|c|c|c|c|c|c|c|c|c|}
\hline \multirow[b]{3}{*}{ Year } & \multirow{2}{*}{\multicolumn{2}{|c|}{$\begin{array}{l}\text { Markagunt Plateau and } \\
\text { surrounding highlands }\end{array}$}} & \multicolumn{5}{|c|}{ Parowan Valley } & \multirow{3}{*}{$\begin{array}{c}\text { Change in } \\
\text { storage, in acre-feet } \\
(-) \text { values indicate } \\
\text { depletion in storage }\end{array}$} \\
\hline & & & \multirow[b]{2}{*}{$\begin{array}{l}\text { Recharge from } \\
\text { streambed } \\
\text { seepage, } \\
\text { in acre-feet }\end{array}$} & \multicolumn{2}{|c|}{ Irrigation recharge, in acre-feet } & \multirow[b]{2}{*}{$\begin{array}{l}\text { Discharge from } \\
\text { pumping wells, in } \\
\text { acre-feet }\end{array}$} & \multirow{2}{*}{$\begin{array}{l}\text { Discharge from } \\
\text { groundwater } \\
\text { evapotranspiration, } \\
\text { in acre-feet }\end{array}$} & \\
\hline & $\begin{array}{l}\text { In-place recharge } \\
\text { from precipitation, } \\
\text { in acre-feet }\end{array}$ & $\begin{array}{c}\text { Discharge to } \\
\text { baseflow in } \\
\text { mountain streams, } \\
\text { in acre-feet }\end{array}$ & & Surface water ${ }^{1}$ & Groundwater $^{2}$ & & & \\
\hline 1994 & 14,300 & 14,000 & 1,200 & 3,800 & 1,500 & 30,000 & 200 & $-23,400$ \\
\hline 1995 & 49,400 & 16,000 & 1,400 & 5,100 & 1,200 & 24,000 & 200 & 16,900 \\
\hline 1996 & 14,300 & 14,000 & 1,200 & 3,400 & 1,500 & 29,000 & 200 & $-22,800$ \\
\hline 1997 & 26,700 & 15,000 & 1,300 & 3,700 & 1,300 & 25,000 & 200 & $-7,200$ \\
\hline 1998 & 32,700 & 19,000 & 1,500 & 5,500 & 1,400 & 28,000 & 200 & $-6,100$ \\
\hline 1999 & 21,500 & 16,000 & 1,300 & 4,400 & 1,700 & 33,000 & 200 & $-20,300$ \\
\hline 2000 & 13,300 & 15,000 & 1,300 & 3,800 & 1,500 & 30,000 & 200 & $-25,300$ \\
\hline 2001 & 27,700 & 14,000 & 1,200 & 3,800 & 1,100 & 22,000 & 200 & $-2,400$ \\
\hline 2002 & 2,700 & 11,000 & 1,000 & 3,400 & 2,000 & 39,000 & 200 & $-41,100$ \\
\hline 2003 & 18,000 & 13,000 & 1,100 & 3,700 & 1,600 & 31,000 & 200 & $-19,800$ \\
\hline 2004 & 14,000 & 16,000 & 1,700 & 4,000 & 1,900 & 37,000 & 200 & $-31,600$ \\
\hline 2005 & 71,100 & 19,000 & 1,600 & 6,800 & 1,400 & 27,000 & 200 & 34,700 \\
\hline 2006 & 18,500 & 16,000 & 1,300 & 4,700 & 1,700 & 33,000 & 200 & $-23,000$ \\
\hline 2007 & 12,200 & 14,000 & 1,200 & 3,800 & 1,700 & 34,000 & 200 & $-29,300$ \\
\hline 2008 & 16,800 & 14,000 & 1,100 & 4,300 & 1,900 & 38,000 & 200 & $-28,100$ \\
\hline 2009 & 21,800 & 13,000 & 1,100 & 4,400 & 1,900 & 37,000 & 200 & $-21,000$ \\
\hline 2010 & 32,000 & 14,000 & 1,200 & 4,800 & 1,700 & 34,000 & 200 & $-8,500$ \\
\hline 2011 & 60,800 & 18,000 & 1,500 & 5,600 & 1,600 & 32,000 & 200 & 19,300 \\
\hline 2012 & 15,600 & 16,000 & 1,300 & 4,400 & 1,900 & 38,000 & 200 & $-31,000$ \\
\hline 2013 & 11,800 & 13,000 & 1,100 & 3,900 & 1,600 & 32,000 & 200 & $-26,800$ \\
\hline $\begin{array}{l}\text { Average } \\
\text { (20-year) }\end{array}$ & 24,800 & 15,000 & 1,300 & 4,400 & 1,600 & 32,000 & 200 & $-15,100$ \\
\hline
\end{tabular}

\footnotetext{
${ }^{1}$ Irrigation water is supplied by Parowan, Red, Little, and Summit Creeks.
}

${ }^{2}$ Irrigation water is supplied by pumping wells. 


\section{Infiltration of Precipitation}

The annual in-place recharge to the Parowan Valley groundwater system in 2013 from infiltration of precipitation was estimated to be about 11,800 acre-ft. The average annual in-place recharge to the Parowan Valley groundwater system from 1994 to 2013 was about 24,800 acre-ft (table 4). Most of this recharge occurs in the mountains to the east of the valley. In-place groundwater recharge from precipitation was determined by using the Basin Characterization Model (BCM) (Flint and Flint, 2007), which was used as an input to the numerical model of the study area (Brooks, 2017). The BCM is a distributed-parameter water-balance accounting model used to identify areas having climatic and geologic conditions that allow precipitation to become runoff or in-place recharge and estimate the amount of each. In-place recharge is calculated as the volume of water per time that percolates through the soil zone past the root zone and becomes net infiltration to consolidated rock or unconsolidated deposits. Runoff is a volume of water per time that runs off the surface. Runoff may infiltrate the subsurface farther downslope, undergo evapotranspiration (ET), or become streamflow. The BCM does not track or route runoff to determine its fate. The groundwater budget presented in this report assumes that most of the runoff is captured and is mostly lost to ET via agricultural pressurized irrigation systems. Any large runoff events that overwhelm the diversion systems in the valley are typically short lived and result in minimal recharge volumes in relation to the annual groundwater budget.

The BCM identifies likely locations where runoff and in-place recharge are generated based on the temporal and spatial distribution of precipitation, snowmelt, sublimation, ET, soil-storage capacity, and saturated hydraulic conductivity. The spatial variation of in-place recharge is controlled more by altitude and geology than by other parameters. The highest rates generally occur at the highest altitudes, where precipitation is greatest, and in areas where soil and bedrock are permeable. The BCM simulates very little recharge at valley altitudes. This result is in agreement with ET estimates conducted as part of this study.

From 1994 to 2013, annual in-place recharge ranged from 2,700 to 71,100 acre-ft (table 4). Compared to precipitation, in-place recharge has larger annual variations with higher values occurring during years with greater than average snowpack and lower values occurring during years with below average snowpack (fig. 3). During wetter than normal years, more water is available than is consumed by vegetation, and during dry periods, vegetation generally maintains its normal rate of ET. As a result, there is more groundwater recharge during wet years and less during dry years than would be estimated from a simple relation of recharge to annual precipitation.

\section{Infiltration Through Stream Channel Losses}

Recharge from seepage of mountain streams occurs where surface water is lost to the basin-fill aquifer as the stream crosses high-permeability streambed materials at higher altitudes on the alluvial fans. As discussed in the "SurfaceWater Hydrology" section of this report, this condition only occurs during the winter months when irrigation diversions are not taking place. Routing of mountain stream water is variable, with water from Little Creek, Red Creek, Parowan Creek, and Summit Creek being distributed in areas outside of their natural drainage channels for much of the winter months. Historically, Little Creek and Summit Creek have discharged into gravel pits located on the alluvial fans where groundwater recharge rates are much higher, but this is not consistently implemented. The amount of water that recharges the basin-fill aquifer for each of the mountain streams during the winter months was estimated using these assumptions and ranged from 50 to 540 acre-ft/yr for WY2013 and WY2014 (table 1) with a total of 1,100 acre-ft in 2013 (table 4). The average annual streambed seepage to the basin-fill aquifer during the winter months for the mountain streams from 1994 to 2013 was about 1,300 acre-ft.

\section{Unconsumed Irrigation Water}

Recharge from seepage of unconsumed irrigation water occurs where surface water and groundwater, captured at the mouths of the canyons or from pumped wells, is distributed to agricultural areas located away from the natural discharge channels of the mountain streams or nearby pumping wells. It has been shown that 0 to 50 percent of the water used for irrigation in similar climatic and hydrologic settings is not consumed by crops and becomes recharge to the basin-fill aquifer (Stolp, 1994; Susong, 1995). The variation in the fraction of irrigation water that becomes recharge depends on factors such as the type of irrigation (flood, line sprinkler, center pivot, etc.), crop type, and local soil properties. This groundwater budget assumes that 20 percent of the water applied for irrigation on the alluvial fans becomes recharge, while 5 percent of the water applied for irrigation in the central part of the valley becomes recharge. This assumption is based on the observation that no flood irrigation occurs in the valley, and both surface water and groundwater used for irrigation is distributed via pressurized pipelines to line sprinklers or center pivots. The assumption is also based on the location of the majority of agricultural land in the valley in areas that are dominated by fine-grained sediments that are less likely to receive infiltration at a high rate. During WY2013, it is estimated that 5,500 acre-ft of unconsumed irrigation water from surface and groundwater sources recharged the basin-fill aquifer (table 4). The average recharge from unconsumed irrigation water from 1994 to 2013 was about 6,000 acre-ft.

\section{Discharge}

Discharge from the consolidated-rock aquifer in the adjacent mountains occurs as baseflow to mountain streams and springs. The total amount of baseflow estimated from measurements during WY2013 and WY2014 was about 13,000 acre-ft (table 1). The average annual baseflow from 
1994 through 2013 was about 15,000 acre-ft. For years when in-place recharge is less than baseflow, it is assumed that the baseflow in mountain streams is supported by a decrease in storage in the consolidated-rock aquifer. Total baseflow estimates for 1994 through 2012 were estimated using the same method described in the "Surface-Water Hydrology" section of this report. Hydrographs for Little, Red, Parowan, and Summit Creeks were calculated for 1994 through 2012 using the Missing Streamflow Estimation (MISTE) tool in the USGS Automated Data Processing System (ADAPS) database by building regression equations for each of the historical streamgage sites (Nielsen and Kirby, 2003). Coal Creek (USGS streamgage 10242000), which has been operated continuously from 1915 to the current study period, was used as the reference site for each of the streams entering Parowan Valley. Coal Creek is an ideal reference site for these streams because the Coal Creek drainage occupies a similar geographic area on the Markugunt Plateau and is the next major drainage system south of Parowan Creek.

Discharge from the Parowan Valley basin-fill aquifer occurs almost exclusively as municipal and irrigation well withdrawals, as well as a small amount of ET. Historically, valley springs and flowing wells made up a large portion of the discharge in Parowan Valley (Thomas and Taylor, 1946). Elevated water levels in the valley and within Little Salt Lake also provided for significant amounts of ET from phreatophytes located near the low parts of the valley and around Little Salt Lake. As of 2013, the discharge from historical locations of springs was not observed and discharge from groundwater ET has decreased.

\section{Well Withdrawals}

Withdrawal from wells, principally for irrigation, is the largest component of groundwater discharge in Parowan Valley. Groundwater withdrawals increased from about $15,000 \mathrm{acre}-\mathrm{ft} / \mathrm{yr}$ in 1960 to about 34,000 acre-ft/yr in 1975 and have remained at about this amount for the past 40 years (Burden and others, 2015). The USGS made field visits and discharge measurements about every 3 years from 1997 to 2008 at known irrigation wells in the valley (110 irrigation wells in 2008) as part of a statewide groundwater-use monitoring program in cooperation with the Utah Department of Natural Resources (Burden and others, 2015). Prior to 1997, annual groundwater withdrawals from wells in Parowan Valley were provided in local water commissioner reports. Discharge measurements have been combined with recorded pump power consumption to estimate annual groundwater withdrawals for irrigation in the valley. Field visits to pumped irrigation wells ceased in 2008 at the end of the statewide monitoring program. These wells were revisited during this study, and new power consumption coefficients (PCCs) were defined to allow for an estimate of groundwater withdrawals from irrigation wells during 2013 (Hurr and Litke, 1989).

The historical data set of irrigation well discharge measurements and power consumption records for the valley indicates substantial variation in power rating coefficients over time, even over an irrigation season, for some wells. To understand and help improve the accuracy of the PCC estimation method, discharge at a subset of irrigation wells was continuously metered during the study using totalizing flowmeters (TFMs). Measured discharge at this subset of 15 irrigation wells was combined with estimates based on PCCs for the remaining irrigation wells to calculate total withdrawals of groundwater for irrigation. Discharge from TFMs, where measured, was compared with estimated discharge based on the PCC method to investigate the accuracy of withdrawal estimates. Many irrigation distribution systems in Parowan Valley provide good plumbing configurations for comparison of TFMs with PCCs. Ideal irrigation distribution systems are characterized by a simple configuration of one well that is plumbed to one distribution system with an easily accessible discharge pipe to install TFM instrumentation.

\section{Totalizing Flow Metering}

During the spring of 2013, 15 TFMs were installed by the Utah Department of Natural Resources on wells located throughout Parowan Valley (fig. 14). Two models that were used included the Spirax Sarco UTM10 and the Dynasonics TFXL. Both of these meters have a factory reported accuracy of plus or minus 1 percent. At each of the wells, the TFM was installed inline in a full-flowing, acceptable section of pipe on the discharge side of the pump where the measurement of water velocity was made. An acceptable flowmeter location is defined as a straight, constant diameter length of pipe without turbulence-inducing obstructions.

The total volume of groundwater pumped at the 15 wells was recorded locally at each site using a datalogger and reviewed by a technician on a regular basis. The PCC was checked periodically throughout the summer at each of these well sites. Upon review of the data, two sites that were equipped with TFMs were at locations where the plumbing was discovered to be shared between two wells and could not be used for comparison with the PCCs for those wells.

\section{Power Consumption Coefficient}

Instantaneous flow measurements were made with a portable ultrasonic flowmeter at 86 wells during the summer of 2013 (fig. 14). Typical accuracy of the Controllotron 1010 ultrasonic flowmeter is about 1 to 2 percent (Siemens Industry, Inc., 2013). The ultrasonic flowmeter used in this study employed a transit-time method for flow measurement. Two transducers were mounted on the outside of the discharge pipe and functioned alternately as a transmitter and a receiver of ultrasonic signals sent upstream and downstream through the pipe. The time difference between the signals, averaged in the upstream and downstream directions, is proportional to the velocity of water flow. Generally, 10 or more of the discharge readings were averaged to obtain the instantaneous discharge. 


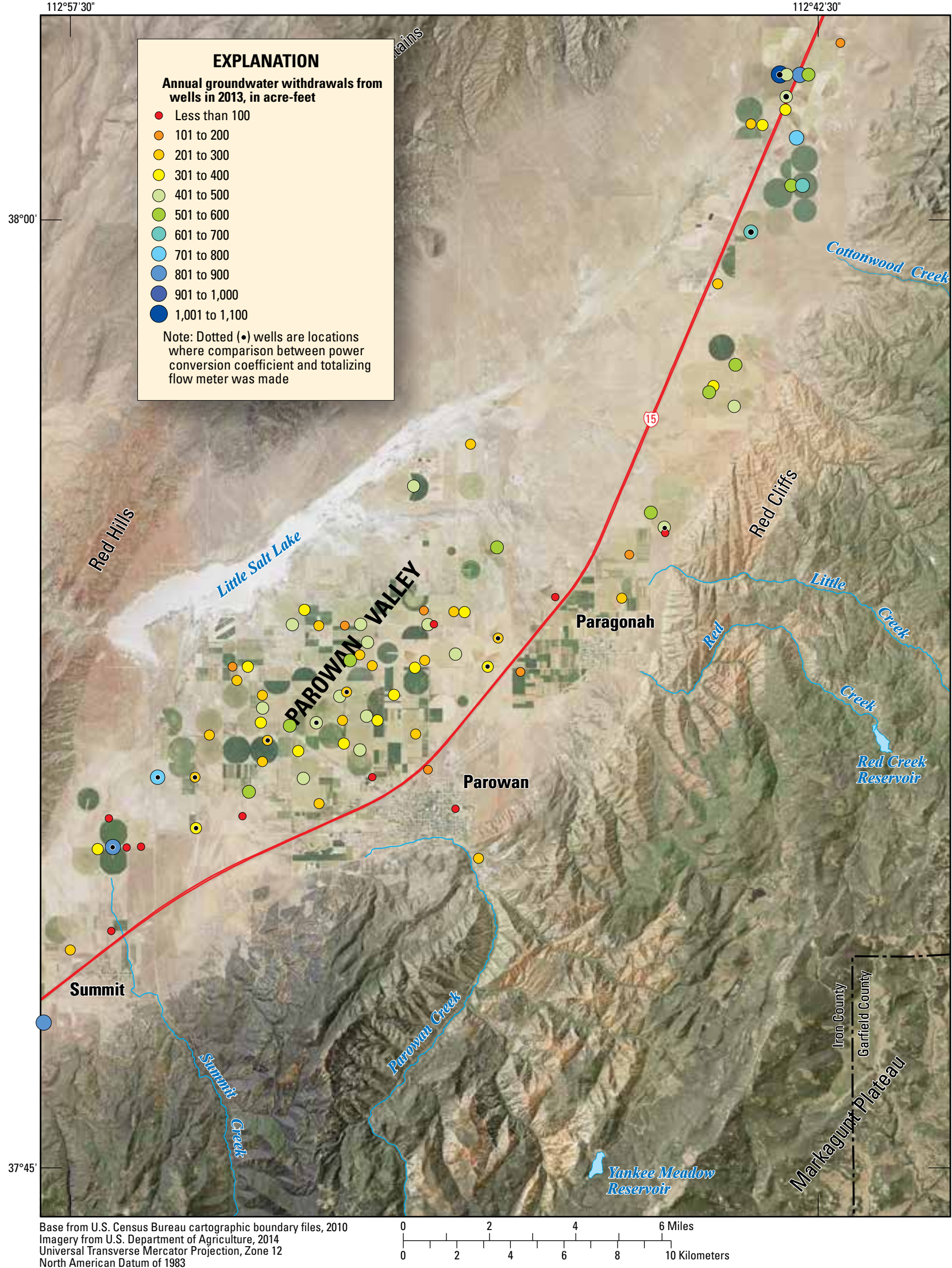

Figure 14. Annual groundwater withdrawals in $\mathbf{2 0 1 3}$ from wells in Parowan Valley, Iron County, Utah. 
The PCC is defined as the number of kilowatt-hours required to pump 1 acre-ft of water. Electrical power meters have a display that indicates the amount of electricity that passes through the meter. During a site visit, the meter was timed with a stopwatch for 10 complete meter cycles to measure the rate per cycle. One cycle is equal to one revolution of the meter dial on an analog meter, and one digital bar cycle on a digital meter. Power demand, in kilowatts, was calculated from the following equation:

$$
\text { power demand }=\text { rate } \times 3.6 \times K h \text { factor }
$$

where

rate is average time of meter cycle, in cycles per second,

3.6 is a conversion factor (kilowatt-seconds per watt-hour), and

$K h$ factor is watt-hours per cycle (imprinted on the front of power meter).

Determining the PCC combines a concurrent measurement of well discharge (in gallons per minute) with the power demand of the pump (in kilowatts).
The PCC, in acre-ft per 1,000 kilowatt-hours, is calculated from the equation

$$
\text { PCC }=\frac{\text { Well discharge } \times 0.1841}{\text { Power demand }}
$$

where

0.1841 is a conversion factor (in gallons per minute to acre-ft per 1,000 kilowatt-hours), and

well discharge is instantaneous groundwater discharge, in gallons per minute.

A PCC was computed for every instantaneous discharge measurement that was made at a well. The PCCs were then used to calculate a total annual discharge for each well based on the annual kilowatt-hours used at each meter/pump pairing (fig. 14). The total annual discharge from well withdrawals in 2013 was about 32,000 acre-ft (table 4).

The total annual discharge based on PCCs for a subset of wells was compared to total annual discharge from wells with TFMs (fig. 15). A simple least squares linear regression of the data yields a coefficient of determination $\left(\mathrm{R}^{2}\right)$ equal to 0.91 and a slope of 1.04. Given the statistically significant high value of $\mathrm{R}^{2}$ and a nearly $1: 1$ relation of the linear regression, application of the PCC method to other wells in Parowan Valley is a good estimate of the total annual groundwater withdrawal by pumping from wells in 2013 .

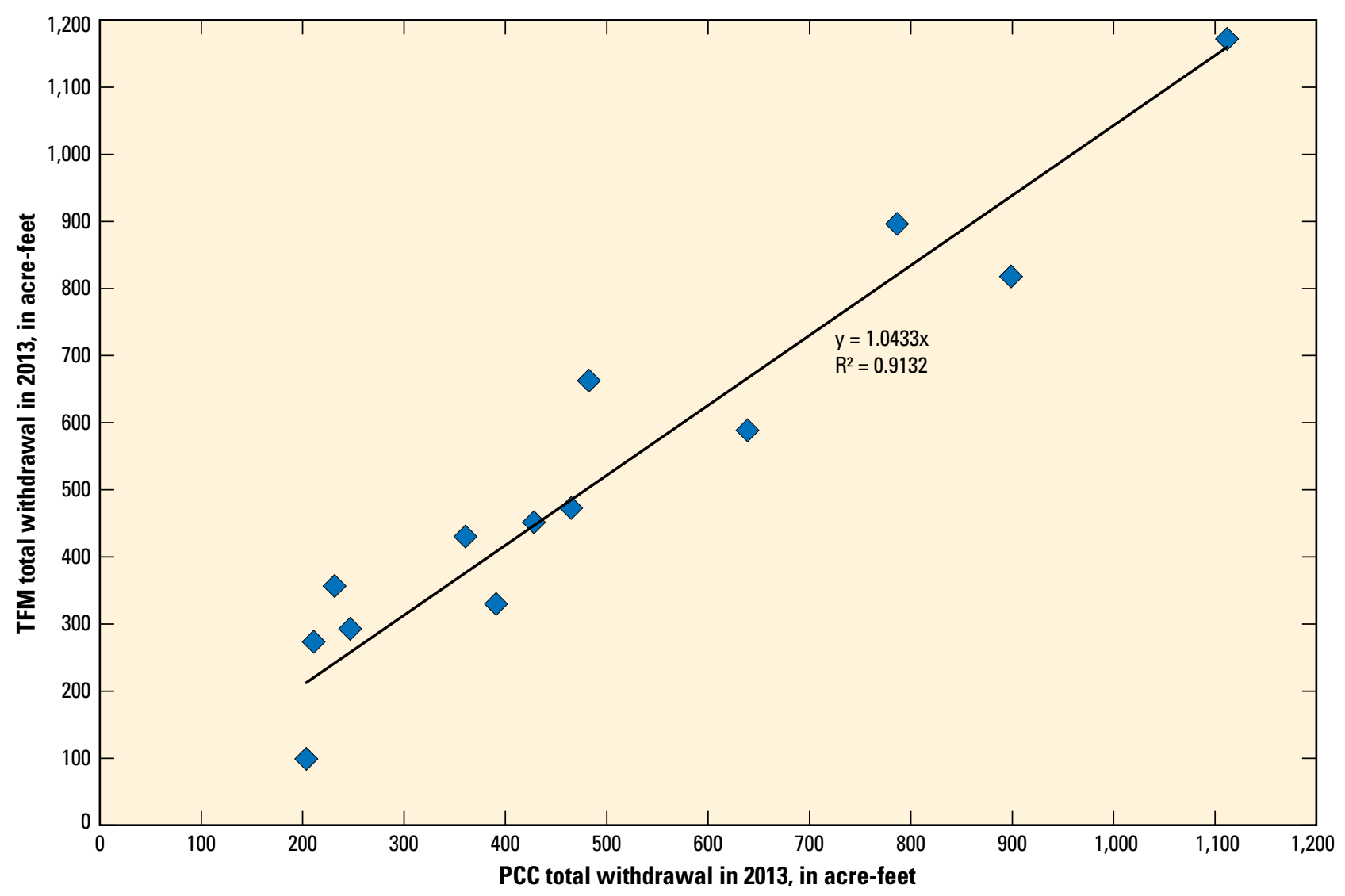

Figure 15. Comparison of annual groundwater withdrawals calculated by the Totalizing Flow Meter (TFM) and Power Consumption Coefficient (PCC) methods for 13 wells in 2013, Parowan Valley, Iron County, Utah. 


\section{Evapotranspiration}

The total volume of water discharged by ET can be calculated as the product of the rate at which water is transferred from the land to the atmosphere (ET rate, in feet per year [ $\mathrm{ft} / \mathrm{yr}]$ ) and the area of the vegetation and open soils that transfer water. Discharge of groundwater by evapotranspiration is the combination of groundwater consumed by plants with roots that extend to the shallow water table and direct evaporation from areas where soils are wetted by shallow groundwater. Groundwater ET, or the fraction of the total ET made up of groundwater $\left(\mathrm{ET}_{\mathrm{g}}\right)$, is calculated by subtracting the annual precipitation from the total ET. Average annual ET $\mathrm{g}$ in Parowan during 2013 was estimated to be about 200 acre-ft (table 4). Historically, $\mathrm{ET}_{\mathrm{g}}$ in Parowan was a greater component of groundwater discharge. Thomas and Taylor (1946) reported 8,700 acre-ft of ET $\mathrm{g}$ from Parowan Valley in 1940. Most of the discharge was through Little Salt Lake and bordering springs around the lake. Water levels in 1940 were only within 1 to 2 in. of the lake bed, resulting in high $\mathrm{ET}_{\mathrm{g}}$ rates for the large surface area of the dry lake. Current water levels beneath Little Salt Lake are about 40 to $50 \mathrm{ft}$ below land surface (fig. 9). The altitude of the Little Salt Lake lakebed is approximately $5,690 \mathrm{ft}$.

During 2014, the extent of the prominent phreatophytes (greasewood and salt grass) was mapped in Parowan Valley (fig. 16). The outer boundary of the ET area delineated in this study approximates the extent of the phreatophytic vegetation (including areas of moist bare soil) where groundwater may be transferred to the atmosphere by ET. Results of ET studies in Nevada suggest that most $\mathrm{ET}_{\mathrm{g}}$ occurs when the water table is within 15 to $20 \mathrm{ft}$ of land surface and that phreatophytes may commonly grow in areas where the depth to water is within $40 \mathrm{ft}$ of land surface (Moreo and others, 2007; Garcia and others, 2015). The boundary delineated in this study encompasses areas in Parowan Valley where depth to water is about $40 \mathrm{ft}$ or less.

Prior to assigning ET rates, the ET area boundary was subdivided into smaller zones (ET units) on the basis of vegetation and land-cover characteristics determined using land-cover and land-use data. An ET unit is an area of similar vegetation or land-cover characteristics that is assigned an ET rate. Southwest Regional Gap Analysis Program (SWReGAP) (Prior-Magee and others, 2007) and Utah Water-Related Land Use (WRLU) inventory data from 2010 (Utah Department of Natural Resources, 2014) were used to identify subareas of common vegetation and land cover. Evapotranspiration rates reported in recent literature (Moreo and others, 2007; Garcia and others, 2015) for vegetation types, land cover, and climate similar to those in the study area were assigned to four ET units in Parowan Valley (fig. 16). Most of the area where ET $_{g}$ is possible in Parowan Valley is undeveloped and covered by the ET units designated as moderately dense to dense desert shrubland. Table 5 contains the rate values used in the ET calculations for each of the ET units.
Because Little Salt Lake is not a significant source of $\mathrm{ET}_{\mathrm{g}}$ due to water-level declines, the only source of $\mathrm{ET}_{\mathrm{g}}$ in the valley is the phreatophytic vegetation. Most of the phreatophytic vegetation types that are present in Parowan Valley can be sustained by average annual precipitation and likely do not significantly impact the groundwater system. Using the estimate of $\mathrm{ET}_{\mathrm{g}}$ during 2013 for water budget calculations from 1994 to 2012 is representative of approximate fluxes that have existed in Parowan Valley since Little Salt Lake was no longer a source of $\mathrm{ET}_{\mathrm{g}}$. On the basis of historical water levels near the lake, this condition likely started in the early 1990s when water levels dropped from about $5 \mathrm{ft}$ below land surface to about $30 \mathrm{ft}$ below land surface over about 5 years. This can be seen in well (C-33-9)33aba-1 (USGS Site 375344112521601), located about $0.5 \mathrm{mi}$ southeast of the dry lake bed.

\section{Subsurface Outflow to Cedar Valley}

Previous studies have concluded that if groundwater moves from Parowan Valley to Cedar Valley, it is likely moving across through the Winn Gap area at the south end of the valley. Thomas and Taylor (1946) cite evidence of shallow bedrock and the narrow highly incised canyon through Parowan Gap as primary reasoning for negligible subsurface flow through the Parowan Gap area. Historically, Enoch Springs discharged near Enoch in Cedar Valley, just southwest of the divide between Parowan Valley and Cedar Valley. The source of this discharge was estimated to be 3,000 acre-ft/yr of the total 5,000 acre-ft/yr of subsurface flow estimated by Thomas and Taylor (1946) from Parowan Valley to Cedar Valley.

Bjorkland and others (1978) reported that subsurface flow from Parowan Valley to Cedar Valley was negligible. They indicated that the Red Hills, which separate the two basins, act as an effective barrier to flow. The direction of groundwater movement shown on the 1974 water-level map in Bjorklund and others (1978), indicates the possibility of some groundwater flow through the Red Hills. The water-level map constructed during this study indicates that some of the water that enters Parowan Valley south of the town of Summit flows southwest toward Cedar Valley (fig. 9). The hydraulic gradient between Parowan and Cedar Valleys is locally high near the southern divide with Parowan Valley, where groundwater levels are about $200 \mathrm{ft}$ higher in altitude than groundwater levels near Enoch.

The boundary between Parowan Valley and Cedar Valley is simulated in the numerical model that was completed as part of this study and is documented in Brooks (2017). The simulated interbasin flow from Parowan Valley to Cedar Valley during 2013 is estimated to be 2,800 acre-ft. Discussion of the simulated impacts of groundwater withdrawals on water levels and historical spring discharge in both valleys, near the interbasin boundary, can be found in Brooks (2017). 


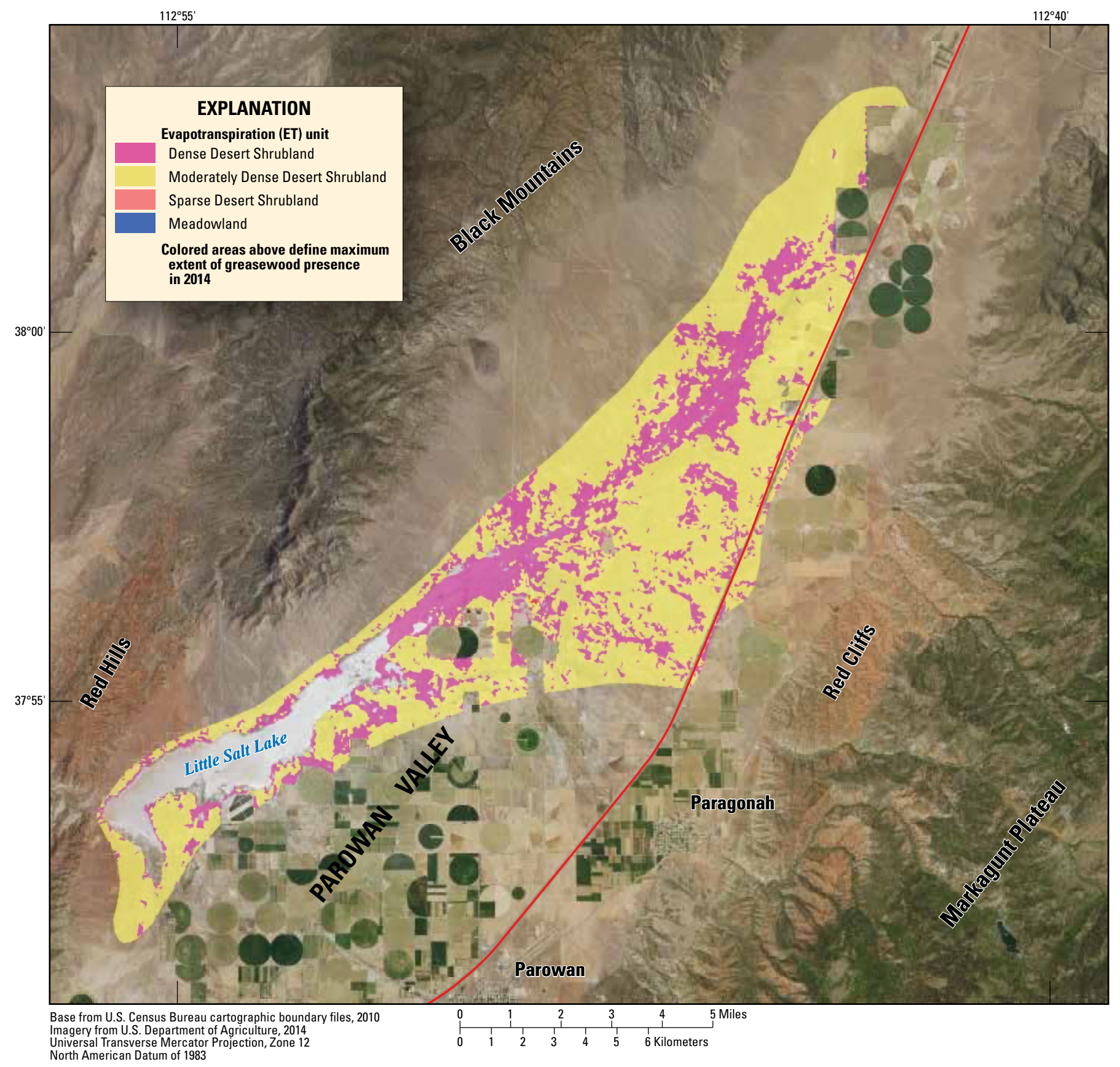

Figure 16. Location and classification of evapotranspiration units used to calculate average annual evapotranspiration of groundwater in Parowan Valley, Iron County, Utah.

Table 5. Evapotranspiration unit rates and areas used to calculate average annual evapotranspiration of groundwater in Parowan Valley, Iron County, Utah.

\begin{tabular}{lcccc}
\hline \multicolumn{1}{c}{ Evapotranspiration (ET) unit } & $\begin{array}{c}\text { ET rate, area } \\
\text { weighted average, } \\
\text { in feet }\end{array}$ & Acres & $\begin{array}{c}\text { Total ET, } \\
\text { in acre-feet }\end{array}$ & $\begin{array}{c}\text { Average annual } \\
\text { precipitation, } \\
\text { in acre-feet }\end{array}$ \\
\hline Dense desert shrubland & 1.06 & 5,720 & 6,060 & $\begin{array}{c}\text { ET from } \\
\text { groundwater, } \\
\text { in acre-feet }\end{array}$ \\
Moderately dense desert shrubland & 1.01 & 15,035 & 15,185 & 5,830 \\
Sparse desert shrubland & 0.84 & 4 & 4 & 15,340 \\
Meadowland & 2.25 & 2 & 5 & 4 \\
\hline
\end{tabular}




\section{Groundwater Chemistry}

Water samples were collected from 46 wells and streams in Parowan Valley (tables 6 and 7). Water samples from 34 wells (municipal, irrigation, and stock) were analyzed for major ions and selected nutrients (nitrate plus nitrite) to characterize general chemistry and water-quality patterns. Water samples from 40 wells and 6 streams were analyzed for the stable isotopes of hydrogen and oxygen to investigate sources of recharge for the basin-fill aquifer in Parowan Valley.

\section{Sample Collection and Analysis}

Samples were collected from wells using the well's dedicated pump. Water was sampled from an outlet as close to the wellhead as possible and before entering any storage or pressure tanks. Field parameters measured during water sample collection included specific conductance, $\mathrm{pH}$, and temperature. These parameters were measured using a calibrated multimeter probe following USGS protocols (Wilde, variously dated). Samples for dissolved major ions and nutrients were processed through a 0.45 -micron filter. The cation subsample bottle was preserved with 7.7N nitric acid. Dissolved major-ion and nutrient analyses were completed by the USGS National Water Quality Laboratory in Denver, Colorado. Unfiltered samples for stable isotopes of oxygen and hydrogen were collected in 50-mL high-density polyethylene (HDPE) bottles with polyseal caps leaving no head space. Stable isotopes of oxygen and hydrogen in water were analyzed at the USGS Stable Isotope Laboratory in Reston, Virginia.

Most water molecules are made up of hydrogen $\left({ }^{1} \mathrm{H}\right)$ and oxygen-16 $\left({ }^{16} \mathrm{O}\right)$. However, some water molecules (less than 1 percent) contain heavier isotopes of deuterium $\left({ }^{2} \mathrm{H}\right.$ or $\left.\mathrm{D}\right)$ and oxygen-18 $\left({ }^{18} \mathrm{O}\right)$. "Heavier" refers to the condition when there are additional neutrons in the nucleus of the hydrogen or oxygen atom, thereby increasing the mass or atomic weight of the water molecule. Stable isotopes are analyzed by measuring the ratio of the heavier, less abundant isotope to the lighter, more abundant isotope and are reported as differences relative to a known standard. The isotopic ratios are reported as delta $(\delta)$ values expressed as parts per thousand (permil). The $\delta$ value for an isotopic ratio, $R$, is determined by

$$
\delta R=\left(\frac{R_{\text {sample }}}{R_{\text {standard }}}-1\right) \times 1,000
$$

where

$\delta R$ is the $\delta$ value for a specific isotope in the sample $\left({ }^{2} \mathrm{H}\right.$ or $\left.{ }^{18} \mathrm{O}\right)$,

$R_{\text {sample }}$ is the ratio of the rare isotope to the common isotope for a specific element in the sample, and

$R_{\text {standard }}$ is the ratio of the rare isotope to the common isotope for the same element in the standard reference material. The reference standard for this isotope is Vienna Standard Mean Ocean Water (VSMOW; Craig, 1961b; Coplen, 1994).
A positive $\delta R$ value indicates that the sample is enriched in the heavier isotope with respect to the standard. A negative $\delta R$ value indicates that the sample is depleted in the heavier isotope with respect to the standard. Heavier isotopes are more difficult to evaporate and easier to condense; for example, liquid water contains more heavy isotopes than the vapor evaporated from the liquid. Because of this effect, water vapor in the atmosphere that condenses and falls as precipitation will become progressively more depleted in the heavier isotopes at cooler temperatures and at higher altitudes. The proportional depletion of ${ }^{2} \mathrm{H}$ and ${ }^{18} \mathrm{O}$ results in isotopic compositions of precipitation (and groundwater sourced from precipitation) that plot along a trend referred to as a meteoric water line when deuterium $\left(\delta^{2} \mathrm{H}\right)$ is plotted against ${ }^{18} \mathrm{O}\left(\delta^{18} \mathrm{O}\right)$.

Cooler (or high-altitude) precipitation values usually plot along the lower end of the trend line, whereas warmer (or lowaltitude) precipitation values plot along the higher end of the trend line. The trend line for worldwide precipitation is termed the Global Meteoric Water Line (GMWL) and is described by the equation

$$
\delta^{2} \mathrm{H}=8\left(\delta^{18} \mathrm{O}\right)+\mathrm{d}
$$

where

$\mathrm{d}$ is defined as the ${ }^{2} \mathrm{H}$ excess (Dansgard, 1964).

The mean global value for $\mathrm{d}$ in freshwater is 10 (Craig, 1961a).

Depending on conditions and sources of precipitation, isotopic data from specific areas may plot along a trend line above or below the GMWL, which is referred to as a local meteoric water line (LMWL). In addition to temperature, isotopic composition is also affected by evaporation, particularly during irrigation or from open-water bodies. Evaporation creates preferential enrichment in ${ }^{18} \mathrm{O}$ relative to ${ }^{2} \mathrm{H}$, resulting in a shift from, and slope less than, the LMWL or the GMWL. Groundwater with "evaporated" stable isotope compositions can often be identified as containing recharge from distinct sources such as lakes and reservoirs.

\section{Results of Analysis}

\section{Major lons and Nutrients}

Analyses of major ions and nutrients were completed on groundwater samples from 34 wells (table 6) to better define groundwater source areas and flow paths, and to assess current water-quality conditions in Parowan Valley. On the basis of general chemistry, the groundwater in Parowan Valley can be divided into water that occurs in the northern part of the valley near Buckhorn Flat, water that occurs in the alluvial fans along the east side of the valley, and water that is located near and within the boundary of Little Salt Lake and the middle of the valley. 


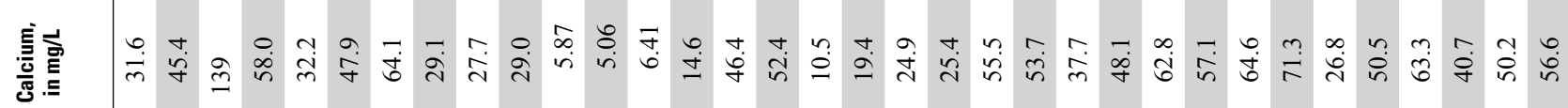
产商

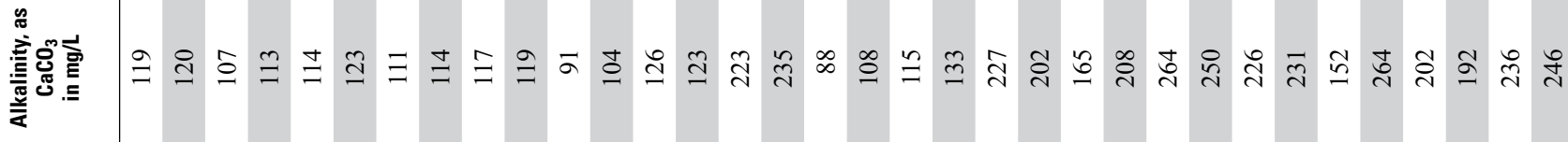

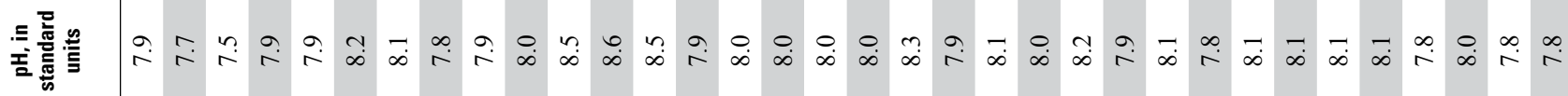
ח 름

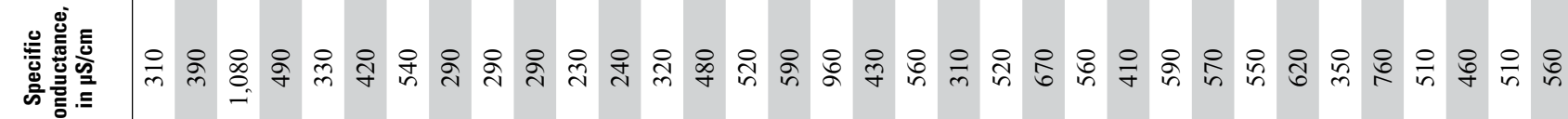

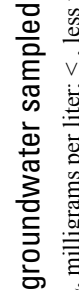$$
\text { . }
$$

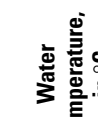

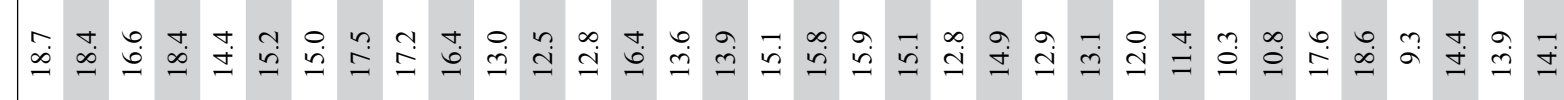

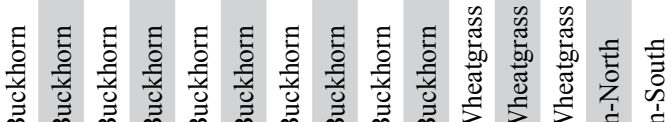

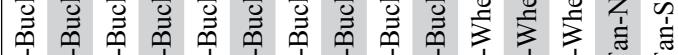

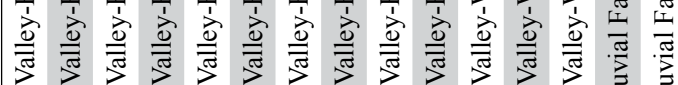

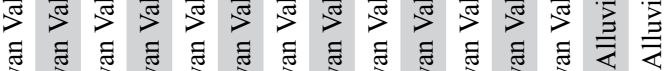
苔言

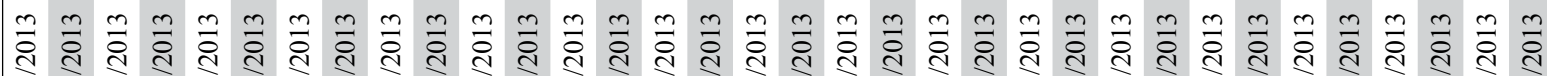

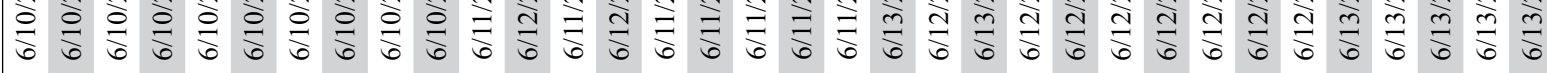

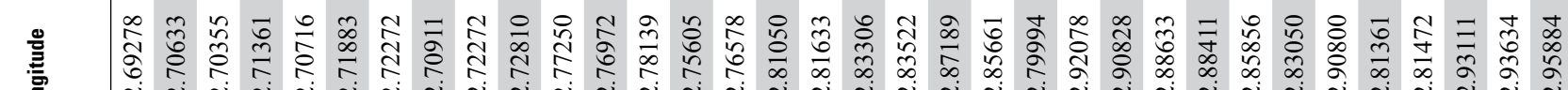

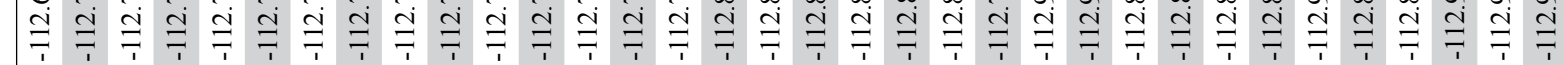

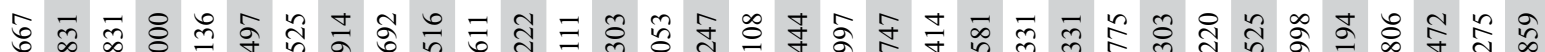

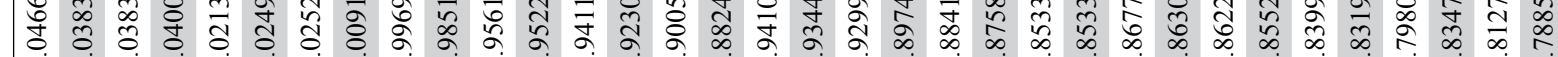

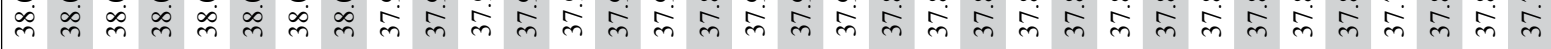

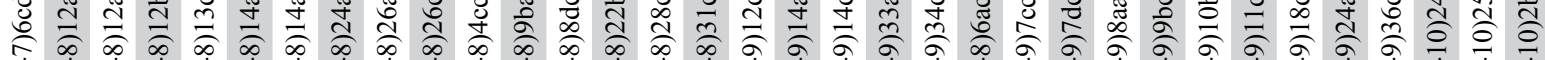
तं

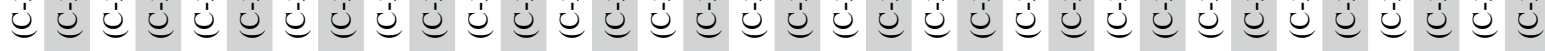

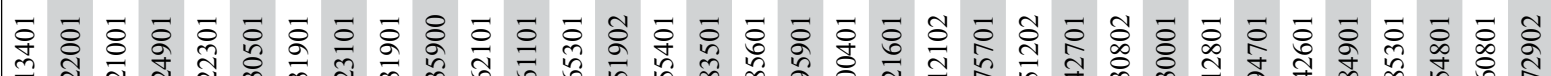

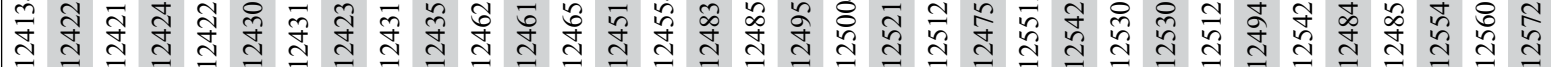

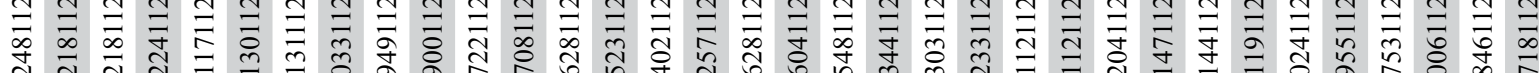

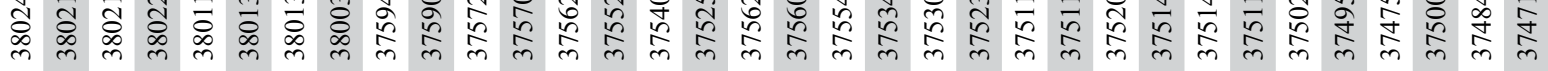




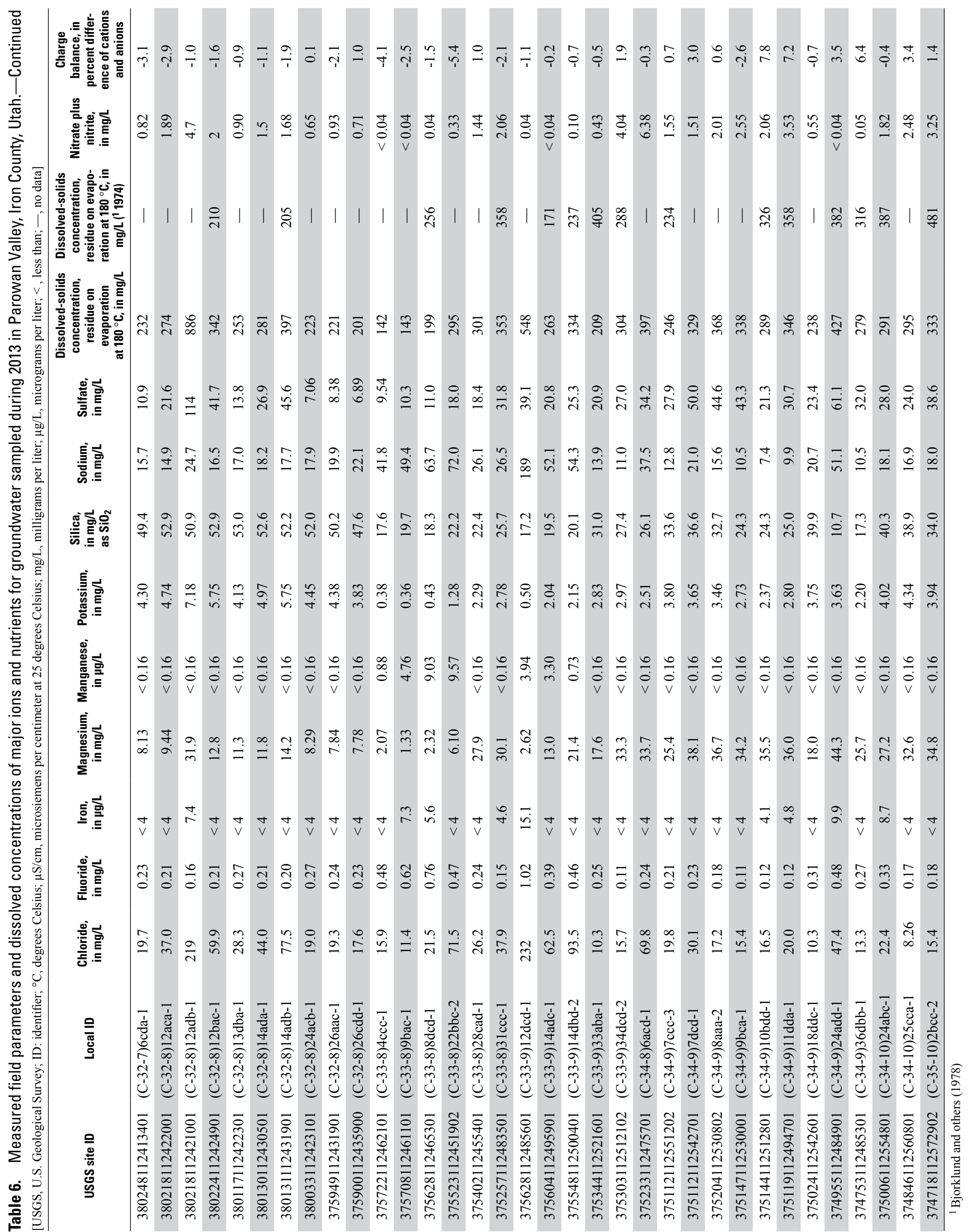


Groundwater that is found in the northern part of the valley is characterized as a calcium-magnesium bicarbonate type. The water composition evolves to a calcium-sodium chloride type as groundwater moves through the middle of the valley downgradient toward Little Salt Lake (fig. 17). The dissolvedsolids concentration in groundwater in the northern part of the valley ranged from 142 to 886 milligrams per liter $(\mathrm{mg} / \mathrm{L})$ (table 6). The highest value was from well (C-32-8)12adb-2, screened in volcanic sediments, which likely contribute to a higher load of dissolved solids.

Groundwater that is present within the alluvial fans on the east side of the valley, which make up the largest geographical area in the valley, is characterized as a calcium-magnesium chloride type. The water composition evolves as it moves downgradient toward Little Salt Lake to a sodium-magnesium-calcium chloride type (fig. 17). The dissolved-solids concentration in groundwater in the eastern and southern parts of the valley ranged from 238 to $427 \mathrm{mg} / \mathrm{L}$ (table 6).

Groundwater that is found near and within the geographical boundary of Little Salt Lake is characterized as a sodium chloride type (fig. 17). The water quality in this area could reflect the impact of dissolution of evaporites associated with historical deposits in the Little Salt Lake playa. The dissolvedsolids concentration in groundwater in the eastern and southern parts of the valley ranged from 295 to $548 \mathrm{mg} / \mathrm{L}$ (table 6). One well located at (C-33-9)12dcd-1 yielded a specific-conductance value of 960 microsiemens per centimeter $(\mu \mathrm{S} / \mathrm{cm})$ at 25 degrees Celsius $\left({ }^{\circ} \mathrm{C}\right)$. This well is located on the northern boundary of the Little Salt Lake geographic area, and likely represents water that is near the end of one of the natural groundwater flow paths at the low point of the valley.

Nitrate plus nitrite concentrations in water from all 34 wells were less than the U.S. Environmental Protection Agency maximum contaminant level (MCL) of $10 \mathrm{mg} / \mathrm{L}$ and ranged from less than 0.04 to $6.38 \mathrm{mg} / \mathrm{L}$ (table 6 ). Concentrations of nitrate plus nitrite above $1 \mathrm{mg} / \mathrm{L}$ occur near areas used for agriculture in the northern and south-central parts of the valley. The lowest concentrations of nitrate plus nitrite occur in the area north of Chimney Meadows and south of Wheatgrass Springs where historically, there were numerous flowing wells, as well as in water from wells that are located at the mouth of Parowan Canyon and near the Forebay diversion structure in Parowan Canyon.

A relation between specific conductance and dissolvedsolids concentration was established for water from the 34 wells sampled for general chemistry to compute the dissolved-solids concentration in 73 pumping wells where specific conductance was measured during PCC/TFM site visits in 2013 (fig. 18). The relation between specific conductance and dissolved-solids concentration in freshwater can be expressed by

$$
A=\frac{\mathrm{Spc}}{\mathrm{DS}}
$$

where

$A$ is the slope of the least squares linear regression line,

Spc is the specific conductance, in microsiemens per centimeter at $25^{\circ} \mathrm{C}$, and

DS is the concentration of dissolved solids, in milligrams per liter.

For the majority of natural waters the value of $A$ is typically between 0.55 and 0.75 . Values that are higher than 0.75 are generally associated with water that is high in sulfate or calcium (Hem, 1992).

Because the water quality in the northern part of the valley is different from the rest of the valley, two linear relations were calculated to derive dissolved-solids concentrations from measured specific conductance of water from pumping wells (fig. 18). The linear regression of specific conductance and dissolved-solids concentration for water from wells located near Buckhorn Flats in the northern part of the valley yielded an $A$ value of 0.84 and an $\mathrm{R}^{2}$ value of 0.99 . The high ratio of dissolved-solids concentration to specific conductance in water from the northern wells is likely because of the higher concentrations of calcium and bicarbonate in the water from many of the wells in that area (fig. 19). Water from well (C-32-8)12adb-2 had a sulfate concentration of $114 \mathrm{mg} / \mathrm{L}$, which represents the high concentration endpoint for water in the northern part of the valley. The linear regression of specific conductance and dissolved-solids concentration for water from wells in the rest of the valley yielded an $A$ value of 0.52 and an $\mathrm{R}^{2}$ value of 0.98 . The lower ratio of dissolved-solids concentration to specific conductance for water from wells in the rest of the valley is likely because of the higher concentrations of chloride relative to bicarbonate in water from the majority of wells in Parowan Valley.

During the 2013 water-quality sampling of wells in Parowan Valley, as many of the wells originally sampled by Bjorkland and others (1978) were re-sampled to evaluate changes in water quality over the last 40 years. Unfortunately, many of the wells that were sampled during the previous study were replaced or destroyed. A comparison of dissolved-solids concentrations was made for 15 wells that were sampled in 2013 and were part of the sampled inventory of wells in 1974. Overall, these comparisons indicated little change in dissolved-solids concentration in the Parowan Valley basin-fill aquifer over the past 40 years. The change in dissolved-solids concentrations in water from the 15 wells sampled from 1974 to 2013 ranged from -196 to $192 \mathrm{mg} / \mathrm{L}$, with a standard deviation of $104 \mathrm{mg} / \mathrm{L}$ normally distributed about the mean change in dissolved-solids concentration of $-0.13 \mathrm{mg} / \mathrm{L}$ (table 6). Although the water sampled from individual wells in 2013 showed significant changes in dissolved-solids concentration compared to 1974 , the overall range in dissolved-solids concentration values for the population of wells sampled in 1974 and 2013 is very similar. Water from both wells that were sampled in the northern part of the valley during the study had 
Table 7. Stable-isotope ratios for groundwater and surface-water samples collected during 2013 in Parowan Valley and northern Cedar Valley, Iron County, Utah.

[USGS, U.S. Geological Survey; ID, identifier; $\delta$, delta; \%, permil]

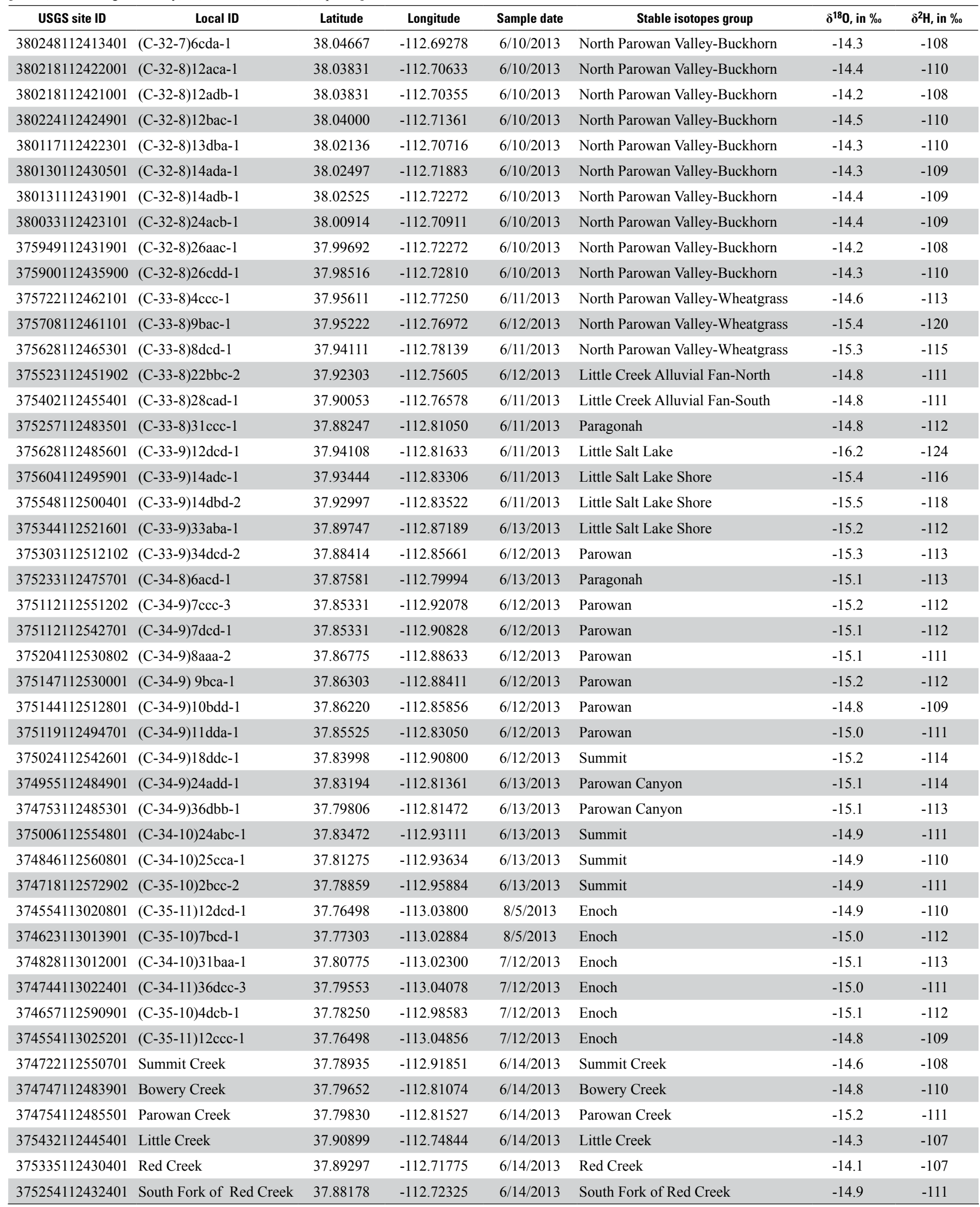




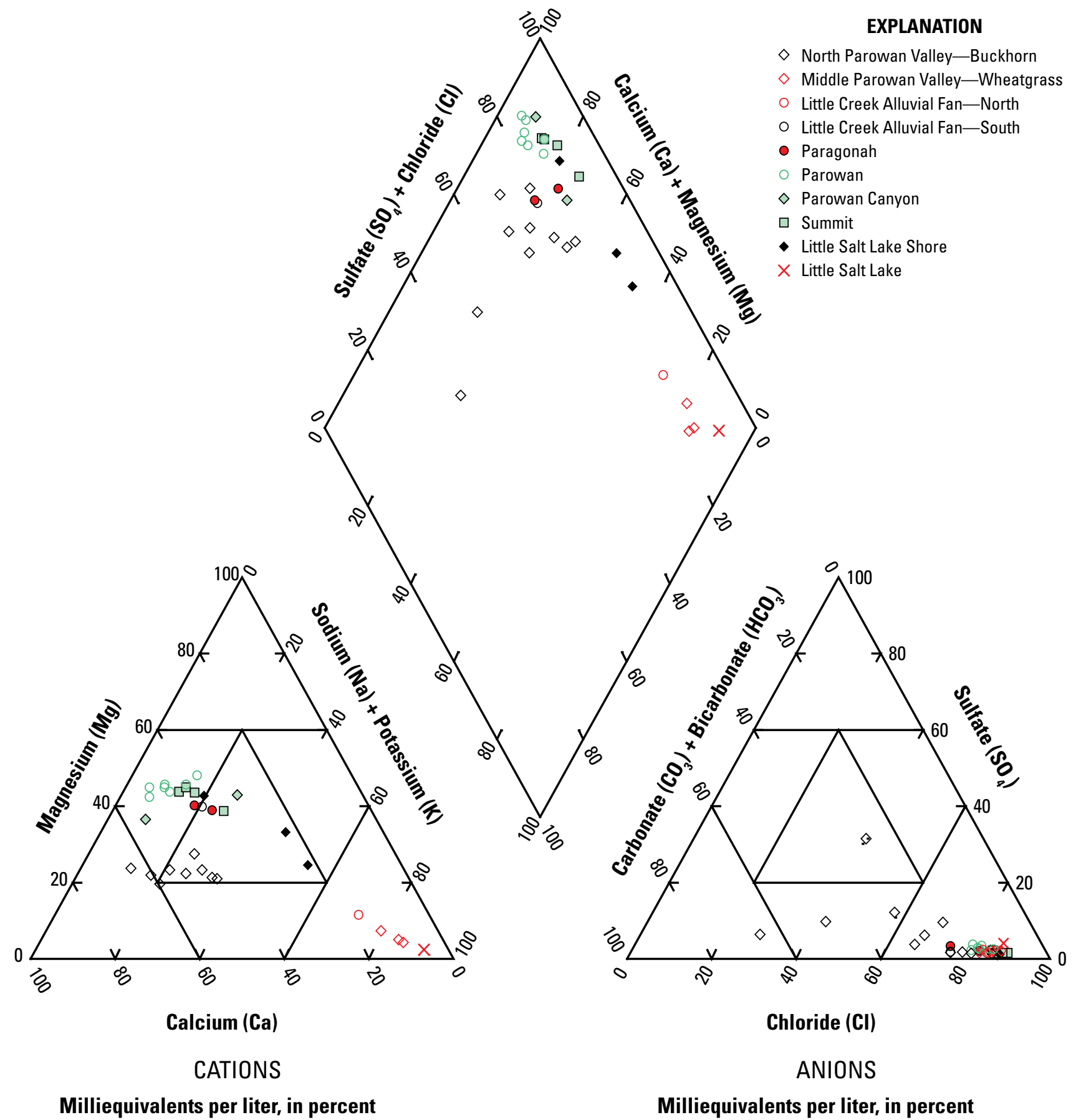

Figure 17. Trilinear diagram showing major-ion water quality for selected wells in Parowan Valley, Iron County, Utah. Relative concentrations of cations and anions are presented in lower left and right triangles, respectively; relative concentrations are projected onto the central diamond to show combined major-ion chemistry. 


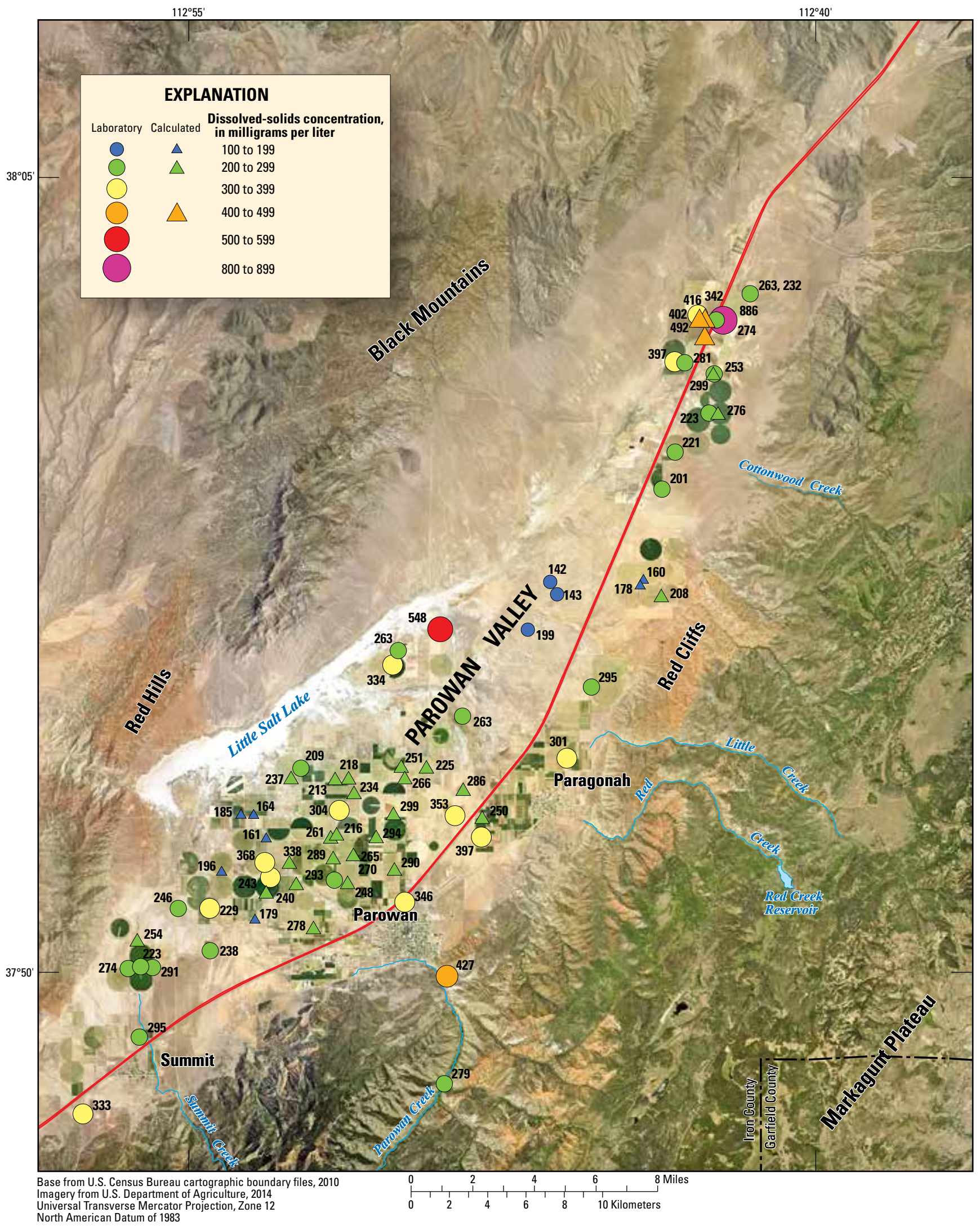

Figure 18. Concentration of measured and calculated dissolved solids in water from 73 wells sampled during 2013 in Parowan Valley, Iron County, Utah. 


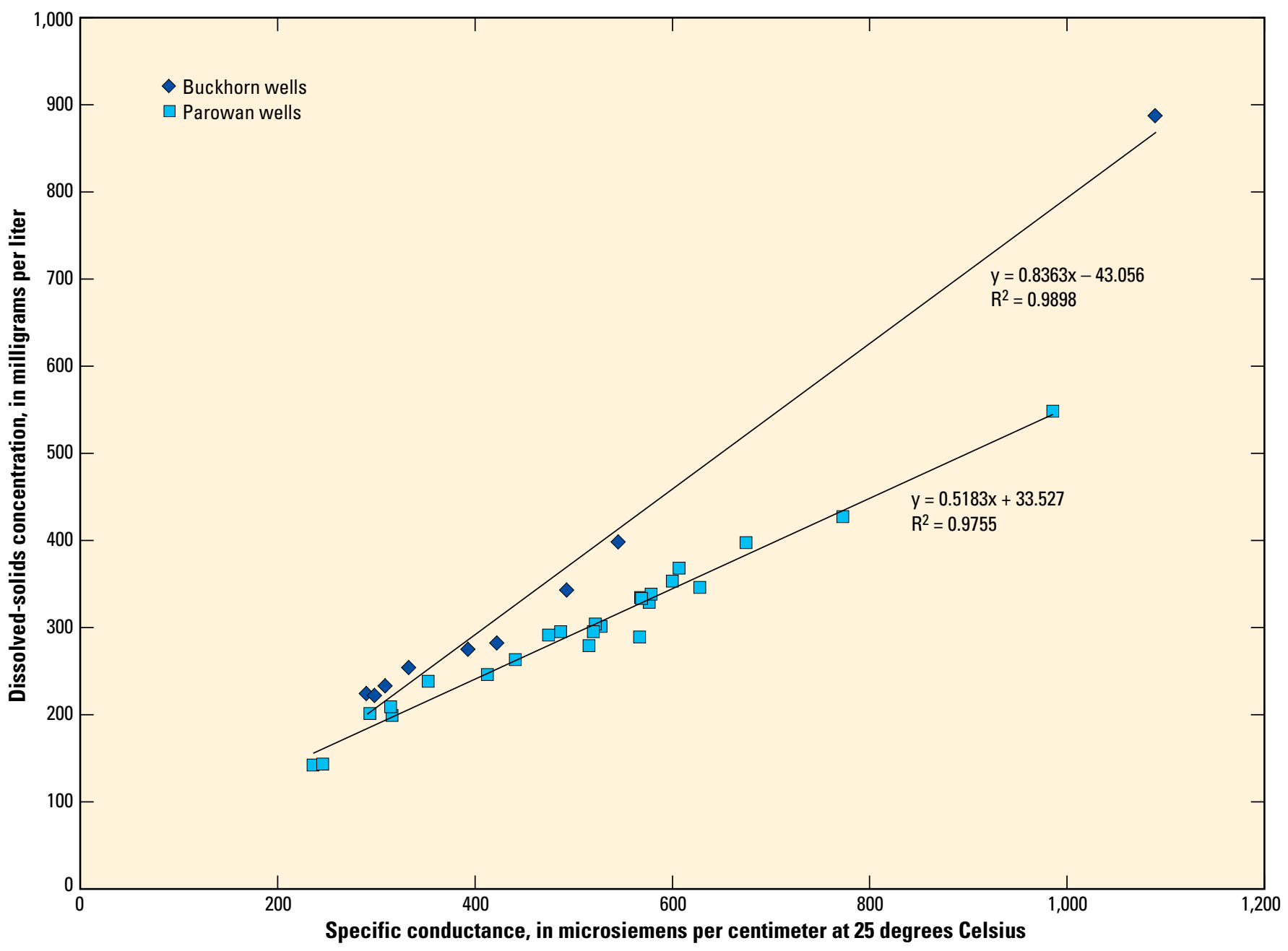

Figure 19. Relation between dissolved-solids concentration and specific conductance in water from 34 wells sampled during 2013 in Parowan Valley, Iron County, Utah.

nearly doubled in dissolved-solids concentration since 1974 (table 6). As stated above, water from well (C-32-8)12adb-2, which is screened in volcanic sediments at the deepest interval in the well, has a much higher dissolved-solids concentration than water from other wells located in the area. It is possible that increased pumping in this part of the valley has induced more flow from deeper parts of the basin-fill aquifer that contain a larger amount of volcanic sediment, and thus, a higher dissolved-solids concentration.

\section{Oxygen-18 and Deuterium}

Analyses of the stable isotopes of hydrogen $\left({ }^{2} \mathrm{H}\right)$ and oxygen $\left({ }^{18} \mathrm{O}\right)$ were completed for groundwater samples from 40 wells and for water samples from 6 mountain streams (fig. 20 and table 7) to investigate groundwater source areas for the Parowan Valley basin-fill aquifer and the northern Cedar Valley aquifer near the town of Enoch. Stable-isotope ratios of all groundwater and surface-water samples collected during 2013 plot between the GMWL and the Arid-Zone LMWL (Welsh and Priessler, 1986) (fig. 21).
Precipitation on the Markagunt Plateau is represented isotopically by the samples from six mountain streams on the east side of Parowan Valley (fig. 21). The isotopic signature of the majority of the groundwater samples is similar to the mountain stream samples (fig. 21 and table 7). This result is in agreement with the conceptualization of a valley aquifer system in which a high percentage of aquifer recharge is sourced from the high-altitude mountainous region to the east of the valley, not local recharge from precipitation on the valley floor. The groundwater samples from wells located in the northern part of the valley near Buckhorn Flat have the least depleted isotopic composition and further indicate that the source of groundwater to the northern part of the valley is different than for the rest of the valley. The heavier isotopic composition of the northern valley water could indicate a lower elevation recharge area, given that the highest altitudes in the recharge area to the east on the Markagunt Plateau are above the southern end of Parowan Valley near Brian Head.

Groundwater from six wells sampled near Enoch plot in the same grouping as the majority of the samples obtained from wells in Parowan Valley. The similar isotopic values for 


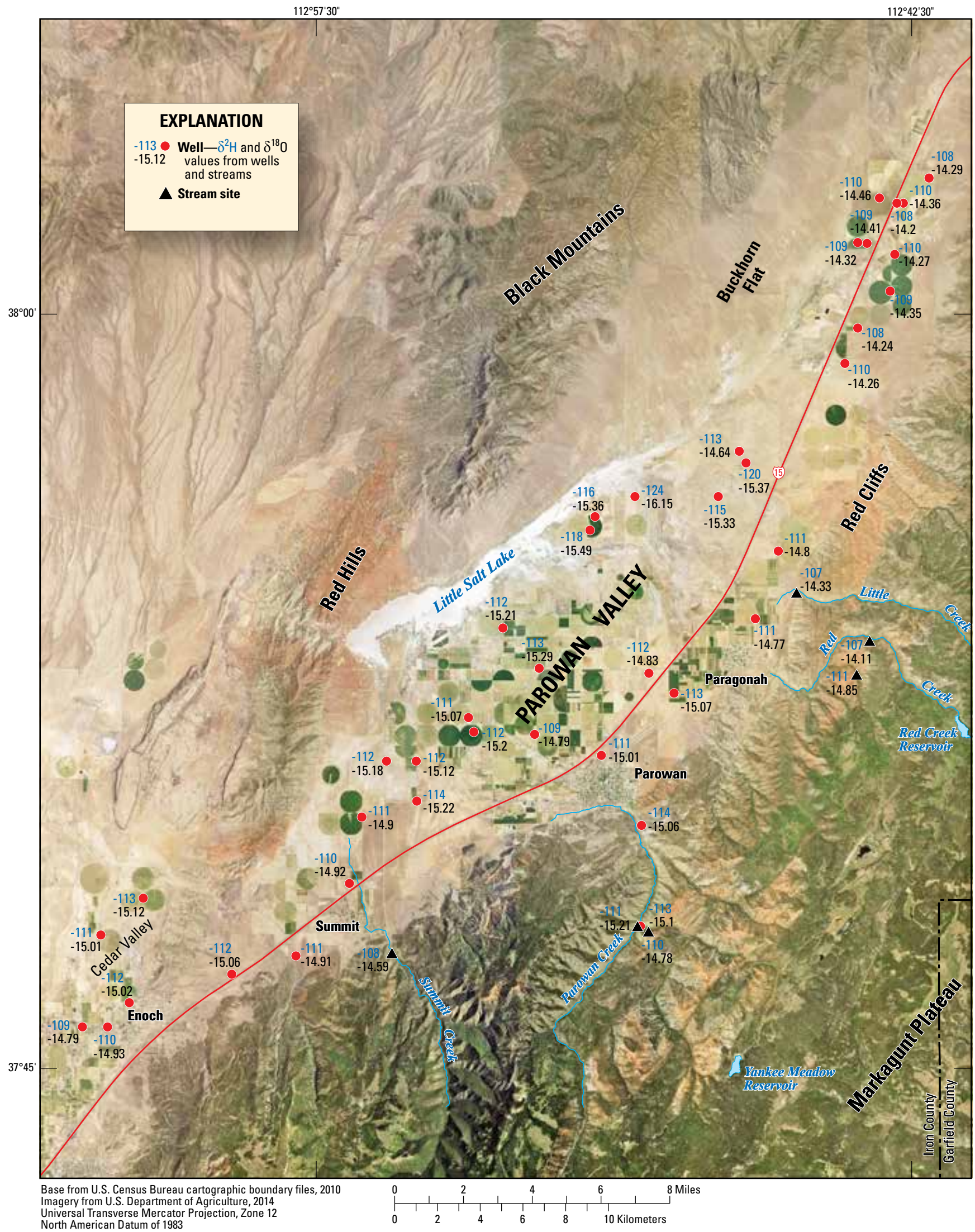

Figure 20. Locations of samples analyzed for stable isotopes in groundwater and surface water during 2013 in Parowan Valley and northern Cedar Valley, Iron County, Utah. 


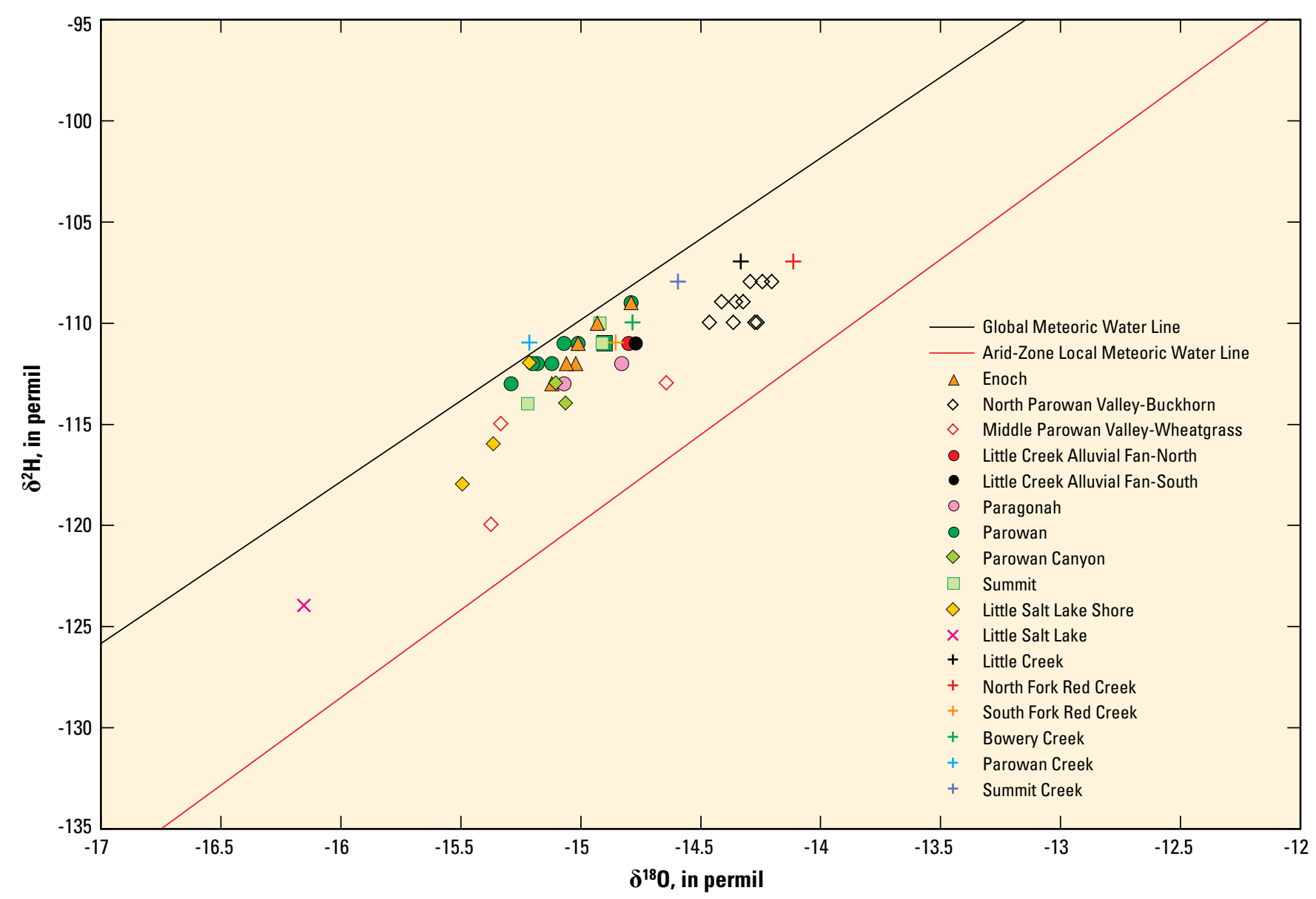

Figure 21. Relation between delta deuterium $\left(\delta^{2} \mathrm{H}\right)$ and delta oxygen-18 $\left(\delta^{18} \mathrm{O}\right)$ for ground and surface-water samples collected in 2013 from Parowan Valley, Iron County, Utah.

groundwater sampled from wells near Enoch indicate that the source of water that recharges the Enoch area is similar to the source of water that recharges the southern part of Parowan Valley and is represented by the Summit, Parowan, and Parowan Canyon groups on figure 21 and in table 7. This result does not necessarily imply that the water sampled from wells near Enoch flowed through a portion of Parowan Valley, but rather that the water likely recharges on the Markagunt Plateau to the east of the area.

Groundwater from three of the four wells located within or near the geographical boundary of Little Salt Lake is isotopically more depleted in both ${ }^{18} \mathrm{O}$ and ${ }^{2} \mathrm{H}$ (sites that are less than -15.4 permil $\delta^{18} \mathrm{O}$ and less than -115 permil $\delta^{2} \mathrm{H}$ ) than the rest of the samples collected in 2013 (fig. 21). These samples are substantially more depleted than any of the mountain streamwater samples, and reflect the isotopic composition of the winter precipitation stored in snowpack at high altitude. These samples plot below the modern $\delta^{2} \mathrm{H}$ compositions of winter precipitation for the region, which are typically about -115 to -105 permil (Smith and others, 2002). It has been shown that groundwater in the Great Basin that is substantially isotopically lighter than modern precipitation may have been recharged during the Pleistocene Epoch. The source of the isotopically depleted recharge water in the Pleistocene would have been recharge from beneath glaciers, from glacier meltwater, or from direct precipitation (Smith and others, 2002). The Markagunt Plateau lies at the southernmost extent of Pleistocene glaciation, with evidence of glacial deposits occurring east of Brian Head (Mulvey and others, 1984). 


\section{Summary}

The water resources of Parowan Valley, in southwestern Utah, were assessed during 2012 to 2014, with an emphasis on refining the understanding of the groundwater and surface-water systems and updating the groundwater budget. Groundwater occurs in and has been developed mainly from the unconsolidated basin-fill aquifer that underlies the valley. Long-term declining trends in groundwater levels have been documented by the USGS since the mid-1950s. Annual groundwater withdrawals increased from about 15,000 acre-feet in 1960 to about 34,000 acre-feet by 1975 and have remained at about this amount for the past 40 years. Surfacewater resources make up a significant portion of the water availability in the valley and are generally used for agriculture on the east side of the valley around the towns of Summit, Parowan, and Paragonah. Parowan Valley is essentially a closed basin with Little Salt Lake functioning as a terminus for most surface-water flows, although a small part of the valley at the southwestern end drains through Winn Gap into Cedar Valley.

The total annual surface-water discharge of five perennial mountain streams entering Parowan Valley during 2013 to 2014 was about 18,000 acre-feet compared to the average annual streamflow, based on partial historical records, of about 22,000 acre-feet. From north to south, Cottonwood Creek, the smallest stream, discharged about 370 acre-feet to the valley during 2013 to 2014, with a range in instantaneous discharge of 0.44 to 0.74 cubic feet per second $\left(\mathrm{ft}^{3} / \mathrm{s}\right)$. Little Creek discharged about 1,100 acre-feet to the valley, with a range in instantaneous discharge of 0.30 to $9.5 \mathrm{ft}^{3} / \mathrm{s}$. Red Creek discharged about 4,900 acre-feet to the valley, with a range in instantaneous discharge of 4.4 to $11.7 \mathrm{ft}^{3} / \mathrm{s}$. Parowan Creek, the largest stream entering the valley, discharged about 9,900 acre-feet to the valley during 2013 to 2014, with a range in instantaneous discharge of 6.5 to $28.1 \mathrm{ft}^{3} / \mathrm{s}$. Summit Creek discharged about 1,700 acre-feet to the valley, with a range in instantaneous discharge of 0.88 to $14 \mathrm{ft}^{3} / \mathrm{s}$ for the same time period.

It is assumed that most recharge to the groundwater system occurs as direct infiltration of snowmelt and rainfall on the Markagunt Plateau east of the valley. Average annual in-place recharge as infiltration of precipitation to the Parowan Valley groundwater system was estimated to be about 25,000 acre-feet per year from 1994 to 2013. The basin-fill aquifer in Parowan Valley receives most of its recharge from either subsurface discharge from the adjacent consolidatedrock aquifer or from infiltration of streamflow and unconsumed irrigation water along the east side of the valley on alluvial fans associated with mountain streams at the foot of the Red Cliffs. Almost all groundwater discharge occurs as withdrawals from irrigation wells in the valley with a very small amount of discharge from evapotranspiration. Withdrawals from wells during 2013 were about 32,000 acre-feet. Withdrawals from wells ranged from 22,000 to 39,000 acre-feet per year from 1994 to 2013. Discharge by evapotranspiration of groundwater has been substantially diminished from pre-development values of 8,700 acre-feet in 1940 to about 200 acre-feet in 2013. Long-term trends in declining groundwater levels in Parowan Valley have been documented by the U.S. Geological Survey since the mid-1950s, and groundwater flow gradients and observed responses to well withdrawals in the valley indicate that the basin-fill aquifer is hydrologically connected throughout the entire length of the valley. Water levels in the basin-fill aquifer have declined by as much as 90 feet in the southern part of Parowan Valley near the town of Parowan and by as much as 30 feet in the northern part of the valley over the last 40 years. Declining water levels from 1994 to 2013 correspond to an average estimated annual decrease in groundwater storage of about 15,000 acre-feet. Any subsurface groundwater discharge to Cedar Valley has likely been diminished as a result of declining water levels in Parowan Valley.

Groundwater and surface-water samples were collected from 46 sites in Parowan Valley and Cedar Valley near Enoch during June 2013. Groundwater samples from 34 wells were submitted for chemical analysis. The dissolved-solids concentration in water from these wells ranged from 142 to 886 milligrams per liter. Major-ion chemistry from wells in the northern part of the valley near Buckhorn Flat showed chemical characteristics that are distinct from water in the rest of the valley. The water from the northern part of the valley is characterized as a calcium-magnesium bicarbonate type, whereas water from the rest of the valley is characterized as a calcium-magnesium chloride to sodium-magnesium chloride type, depending on proximity to Little Salt Lake. The chemical evolution of water originating in the northern part of the valley is similar to the chemistry of the water observed around Little Salt Lake, indicating that the northern part of the valley is hydrologically connected to the southern part. Stable-isotope values of oxygen $\left({ }^{18} \mathrm{O}\right)$ and deuterium $\left({ }^{2} \mathrm{H}\right)$ analyzed from groundwater and surface-water samples indicate that most of the groundwater in Parowan Valley and in Cedar Valley near Enoch is similar in isotopic composition to water in mountain streams entering the valley, which reflects meteoric water recharged in high-altitude areas on the adjacent Markagunt Plateau. Water from wells in the northern part of the valley has a slightly less depleted isotopic composition than in samples collected from the rest of valley, indicating a precipitation source that is lower in altitude than that for wells in the rest of Parowan Valley. A subset of isotopically depleted samples from wells near Little Salt Lake indicates cooler Pleistocene precipitation as a possible source of recharge.

\section{Acknowledgments}

A special note of gratitude is given to previous USGS employee Jacob Benson from the Cedar City Field Office. Much of the field efforts and resulting data associated with this project greatly benefited from his knowledge of both the geographic study area and familiarity with local residents and landowners in Parowan Valley. 


\section{References Cited}

Biek, R.F., Rowley, P.D., Anderson, J.J., Maldonado, F., Moore, D.W., Eaton, J.G., Hereford, R., and Matyjasik, B., 2012, Interim geologic map of the Panguitch 30'x 60' quadrangle, Garfield, Iron, and Kane Counties, Utah: Utah Department of Natural Resources Open-File Report No. 599, 124 p.

Bjorklund, L.J., Sumsion, C.T., and Sandberg, G.W., 1977, Selected hydrologic data, Parowan and Cedar City drainage basins, Iron County, Utah: U.S. Geological Survey OpenFile Report (unnumbered but duplicated as Utah Basic-Data Release No. 58), 55 p.

Bjorklund, L.J., Sumsion, C.T., and Sandberg, G.W., 1978, Ground-water resources of the Parowan-Cedar City drainage basin, Iron County, Utah: Utah Department of Natural Resources Technical Publication No. 60, 93 p.

Brooks, L.E., 2017, Numerical simulation of Parowan, Pine, and Wah Wah Valleys utilizing GBCAAS model version 3: U.S. Geological Survey Scientific Investigations Report 2017-5072, $77 \mathrm{p}$.

Brooks, L.E., and Mason, J.L., 2005, Hydrology and simulation of ground-water flow in Cedar Valley, Iron County, Utah: U.S. Geological Survey Scientific Investigations Report 2005-5170, 114 p.

Burden, C.B., and others, 2015, Groundwater conditions in Utah, spring of 2015: Utah Department of Natural Resources Cooperative Investigations Report No. 56, 136 p.

Coplen, T.B., 1994, Reporting of stable hydrogen, carbon, and oxygen isotopic abundances: Pure and Applied Chemistry, v. 66 , no. 2, p. 273-276.

Craig, H., 1961a, Isotopic variations in meteoric waters: Science, v. 133, no. 3465, p. 1702-1703.

Craig, H., 1961b, Standard for reporting concentrations of deuterium and oxygen-18 in natural waters: Science, v. 133, no. 3467 , p. $1833-1834$.

Daly, C., Halbleib, M., Smith, J.I., Gibson, W.P., Doggett, M.K., Taylor, G.H., Curtis, J., and Pasteris, P.A., 2008, Physiographically sensitive mapping of temperature and precipitation across the conterminous United States: International Journal of Climatology, v. 28, no. 15, p. 2031-2064.

Dansgaard, W., 1964, Stable isotopes in precipitation: Talus, v. 16, p. $436-468$.
Flint, A.L., and Flint, L.E., 2007, Application of the basin characterization model to estimate in-place recharge and runoff potential in the Basin and Range carbonate-rock aquifer system, White Pine County, Nevada, and adjacent areas in Nevada and Utah: U.S. Geological Survey Scientific Investigations Report 2007-5099, 20 p.

Freeze, R.A., and Cherry, J.A., 1979, Groundwater: Englewood Cliffs, NJ, Prentice-Hall, 604 p.

Garcia, C.A., Huntington, J.M., Buto, S.G., Moreo, M.T., Smith, J.L., and Andraski, B.J., 2015, Groundwater discharge by evapotranspiration, Dixie Valley, west-central Nevada, March 2009-2011 (ver. 1.1, April 2015): U.S. Geological Survey Professional Paper 1805, 90 p.

Grant, D.M., and Dawson, B.D., 1995, ISCO open channel flow measurement handbook, fourth edition: ISCO Environmental Division, Lincoln, Nebraska, 535 p.

Hem, J.D., 1992, Study and interpretation of the chemical characteristics of natural water: U.S. Geological Survey Water-Supply Paper 2254, $263 \mathrm{p}$.

Hurlow, H.A., 2002, The geology of Cedar Valley, Iron County, Utah, and its relation to groundwater conditions: Utah Geological Survey Special Study 103, 74 p.

Hurr, R.T., and Litke, D.W., 1989, Estimating pumping time and groundwater withdrawals using energy-consumption data: U.S. Geological Survey Water-Resources Investigations Report 89-4107, 27 p.

Meinzer, O.E., 1911, Groundwater in Juab, Millard, and Iron Counties, Utah: U.S. Geological Survey Water-Supply Paper 277, $162 \mathrm{p}$.

Moreo, M.T., Laczniak, R.J., and Stannard, D.I., 2007, Evapotranspiration rate measurements of vegetation typical of ground-water discharge areas in the Basin and Range carbonate-rock aquifer system, Nevada and Utah, September 2005-August 2006: U.S. Geological Survey Scientific Investigations Report 2007-5078, 36 p.

Mulvey, W.E., Currey, D.R., and Lindsay, L.M.W., 1984, Southernmost occurrence of later Pleistocene glaciation in Utah-Brian Head-Signey Peaks area, Markagunt Plateau: Encyclia, no. 61, p. 97-103.

Nielsen, J.P., and Kirby, W.H., 2003, MISTE (MIssing STreamflow Estimation): U.S. Geological Survey Open-File Report 03-123, sec. 4.5.3, version 4.3, 407 p.

Prior-Magee, J.S., Boykin, K.G., Bradford, D.F., Kepner, W.G., Lowry, J.H., Schrupp, D.L., Thomas, K.A., and Thompson, B.C., eds., 2007, Ecoregional gap analysis of the southwestern United States: U.S. Geological Survey Southwest Regional Gap Analysis Project Final Report, Moscow, ID, $441 \mathrm{p}$. 
Sandberg, G.W., 1963, Ground-water data-Beaver, Escalante, Cedar City, and Parowan Valleys, and parts of Washington, Iron, Beaver, and Millard Counties, Utah: Utah State Engineer Basic-Data Report No. 6, 26 p.

Sandberg, G.W., 1966, Ground-water resources of selected basins in southwestern Utah: Utah State Engineer Technical Publication No. 13, 46 p.

Siemens Industry, Inc., 2013, SITRANS F, Ultrasonic Flowmeters FUP1010 IP67 Portable Flowmeter: Operating Instructions, $170 \mathrm{p}$.

Smith, G.I., Friedman, I., Veronda, G., and Johnson, C.A., 2002, Stable isotope compositions of waters in the Great Basin, United States, 3. Comparison of groundwaters with modern precipitation: Journal of Geophysical Research, v. 107, no. D19, 4402, p. ACL16-1-ACL16-15.

Stolp, B.J., 1994, Hydrology and potential for groundwater development in southeastern Tooele Valley and adjacent areas in the Oquirrh Mountains, Tooele County, Utah: Utah Department of Natural Resources Technical Publication No. 107,67 p.

Susong, D.D., 1995, Water budget and simulation of onedimensional unsaturated flow for a flood- and a sprinklerirrigated field near Milford, Utah: Utah Department of Natural Resources Technical Publication No. 109, 32 p.

Thomas, H.E., Nelson, W.B., Lofgren, B.E., and Butler, R.G., 1952, Status of development of selected ground-water basins in Utah: Utah State Engineer Technical Publication No. 7, 96 p.
Thomas, H.E., and Taylor, G.H., 1946, Geology and groundwater resources of Cedar City and Parowan Valleys, Iron County, Utah: U.S. Geological Survey Water-Supply Paper 993, 210 p.

Turnipseed, D.P., and Sauer, V.B., 2010, Discharge measurements at gaging stations: U.S. Geological Survey Techniques and Methods, book 3, chap. A8, 87 p.

U.S. Census Bureau, 2010, Annual estimates of the resident population, April 1, 2010 to July 1, 2014, for cities and towns (incorporated places and minor civil divisions): accessed May 2015, at https://factfinder.census.gov/faces/ nav/jsf/pages/index.xhtml.

Utah Department of Natural Resources, 2014, Downloadable GIS land use data: accessed November 2014, at http://gis.utah.gov/data/planning/water-related-land/.

Welsh, A.H., and Preissler, A.M., 1986, Aqueous geochemistry of the Bradys Hot Springs geothermal area, Churchill County, Nevada, in Subitzky, S., ed., Selected papers in the hydrologic sciences: U.S. Geological Survey Water-Supply Paper 2290, p. 17-36.

Wilde, F.D., ed., variously dated, Field measurements: U.S. Geological Survey Techniques of Water-Resources Investigations, book 9, chap. A6, accessed June 2013, at https://pubs.er.usgs.gov/publication/twri09A6/. 
For additional information, contact:

Director, Utah Water Science Center U.S. Geological Survey

2329 West Orton Circle

Salt Lake City, UT 84119-2047

801 908-5000

http://ut.water.usgs.gov/ 

